
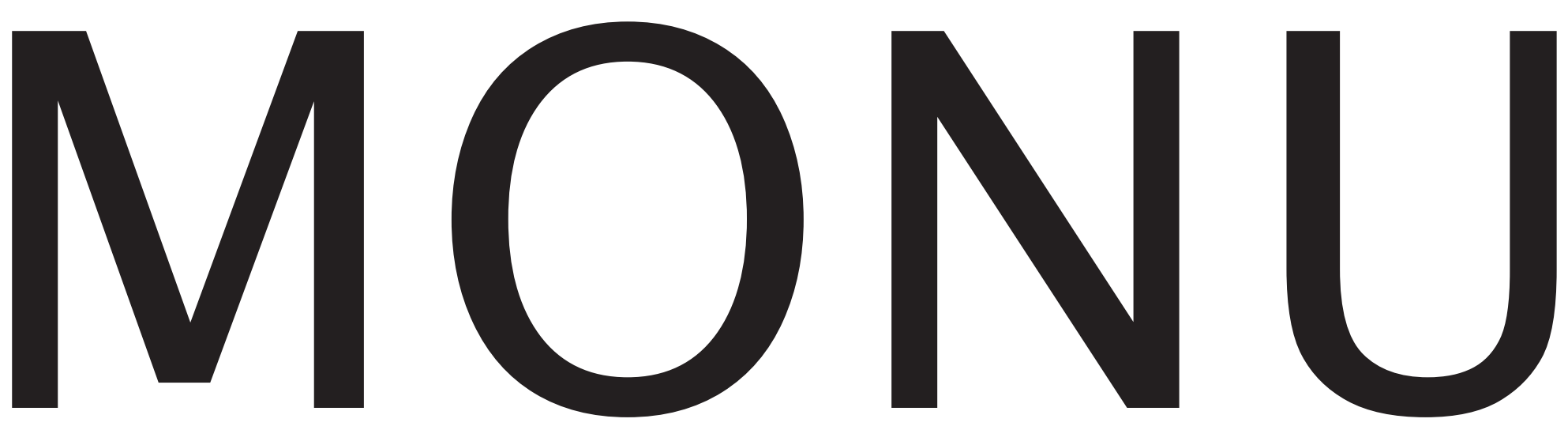


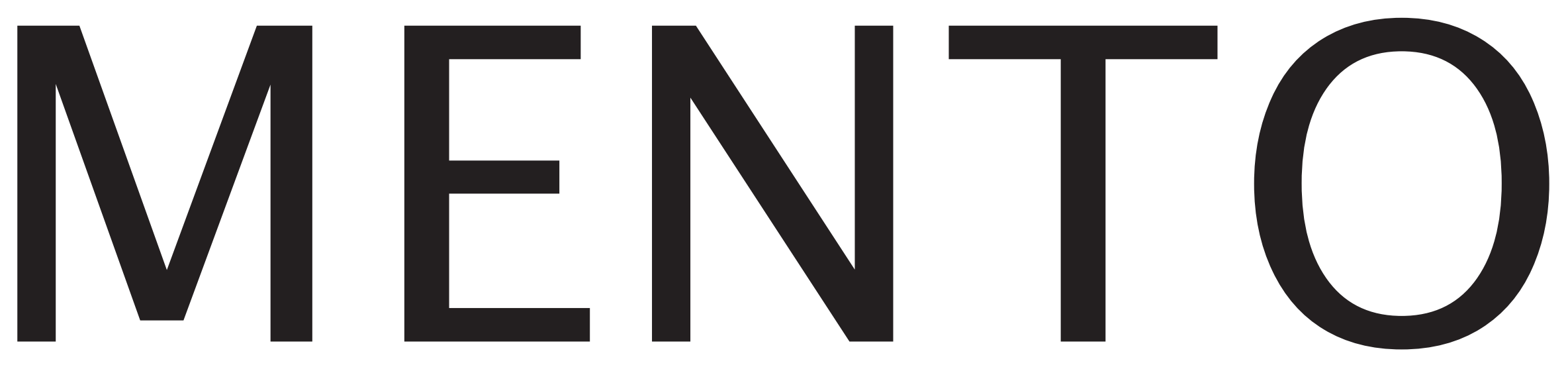




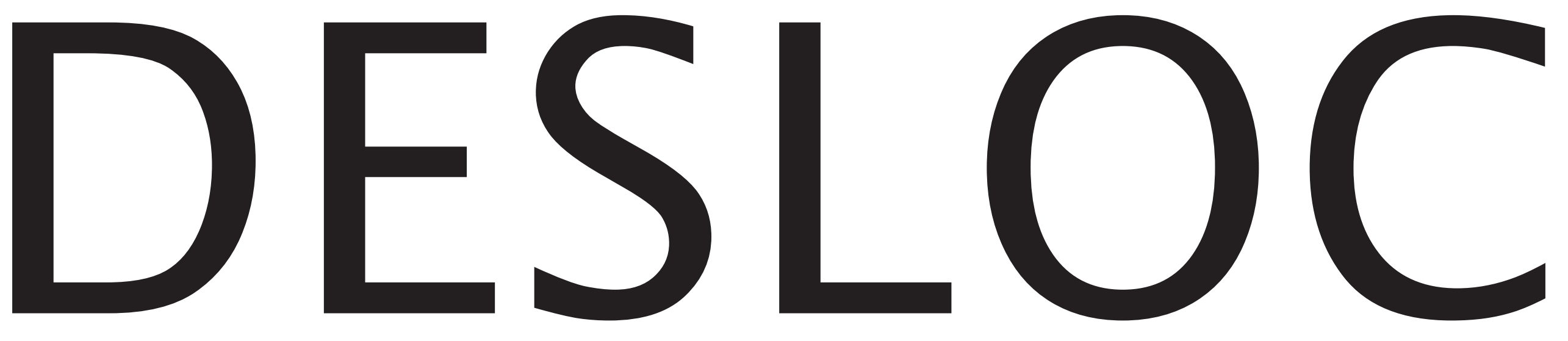




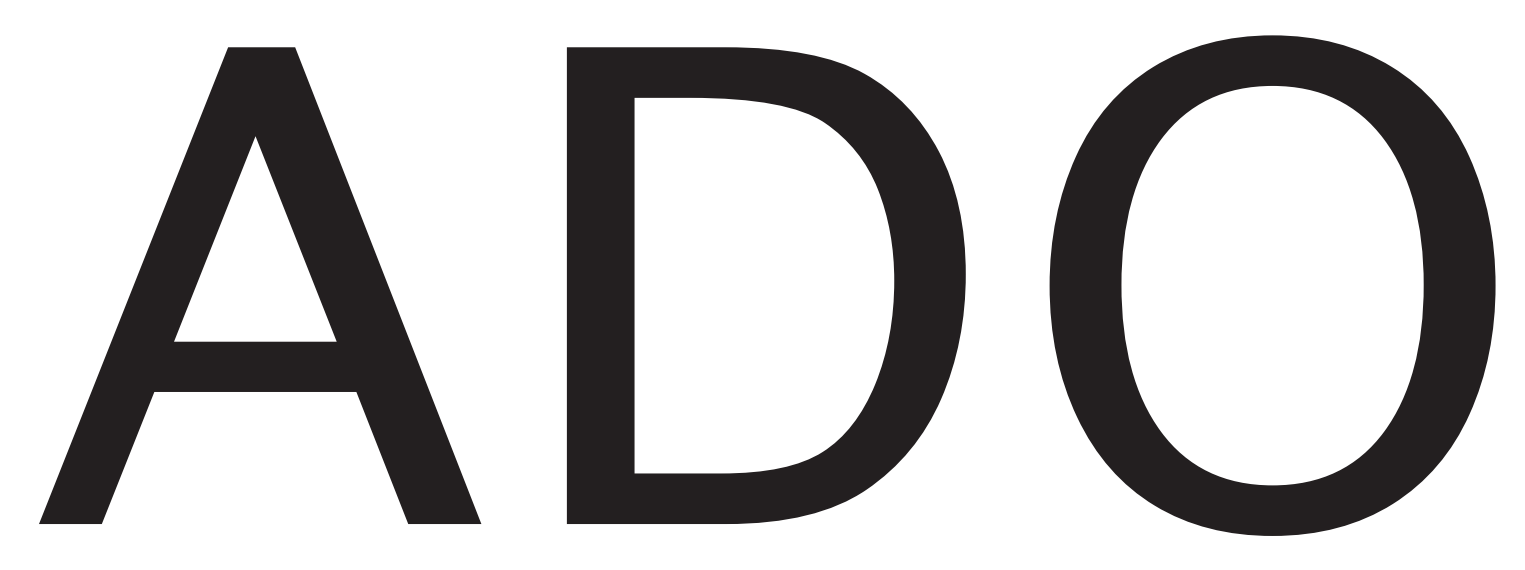




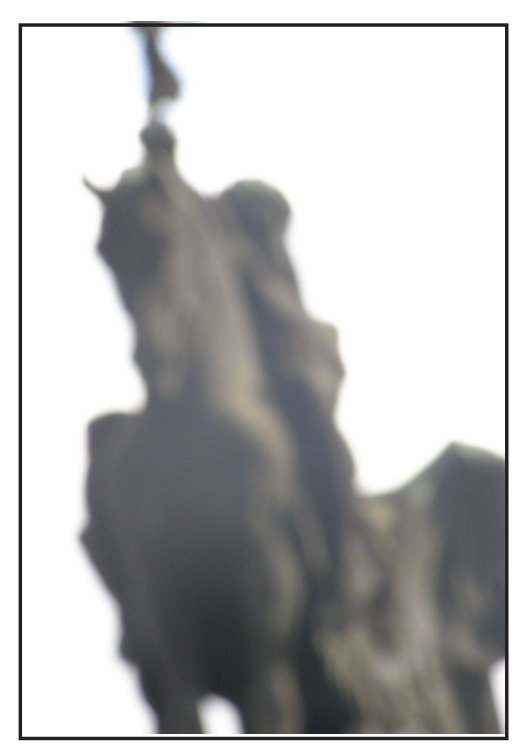




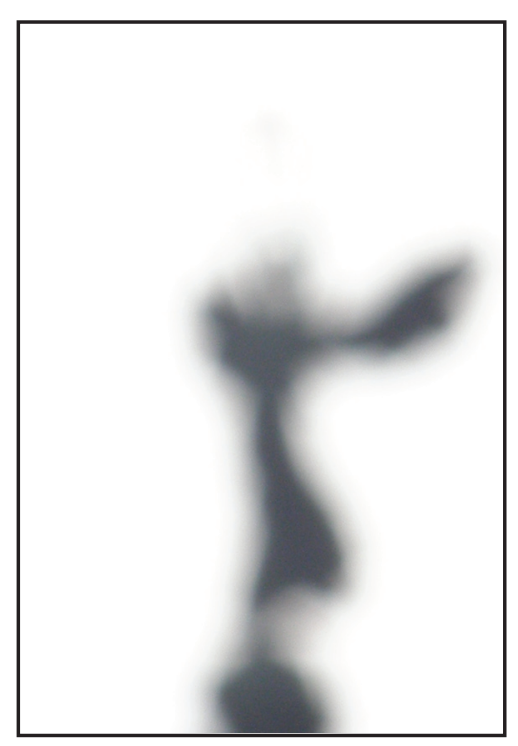


Néstor M. Gutiérrez

\section{Monumento Deslocado}

Dissertação apresentada ao Programa de Pós-Graduação em Artes, Área de Concentração Artes Plásticas, Linha de Pesquisa Poéticas Visuais, da Escola de Comunicações e Artes da Universidade de São Paulo, como exigência para obtenção do título de Mestre em Artes, sob orientação da Profa. Dra. Ana Maria Tavares

março de 2009 

Banca Examinadora

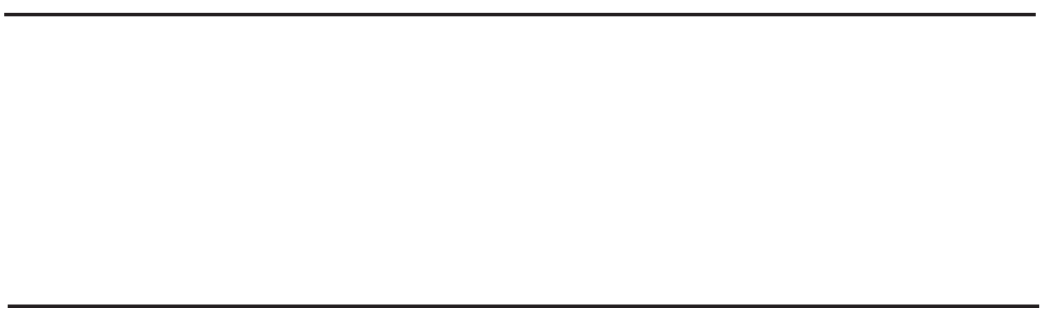

São Paulo,

de 2009 

Resumo

$\mathrm{Na}$ Cidade Universitária há um monumento de proporções épicas que contrasta com o ambiente onde está localizado. Foi deslocado de seu lugar original e se encontra no campus da USP desde 1972. Esta dissertação propõe reflexões acerca da problemática de memória colocada pelo deslocamento do monumento a Ramos de Azevedo e as conseqüências desse movimento. Tais reflexōes partem da interpretação do monumento em relação a diferentes contextos e momentos: seu lugar de origem, a Cidade Universitária, um álbum de fotos que registra sua construção e o projeto para uma exposição artística na Pinacoteca do Estado de São Paulo, que parte da problemática do deslocamento do monumento a Ramos de Azevedo, desenvolvido por Delenguaamano, grupo que integro como artista.

\section{Abstract}

Inside USP's campus there's a monument of epic proportions, which contrasts with the place where it's located. It was displaced from its original site and remains in the campus since 1972. This masters degree project proposes reflections about the memory issues placed by the displacement of the Ramos de Azevedo monument and the consequences of this movement. This reflections interpret the monument in relation to different contexts and moments: it's original site, USP's campus, a photographic album that registers its construction and the project for a contemporary art exposition in the Pinacoteca do Estado de São Paulo, which's departure point was the displacement of the Ramos de Azevedo monument, produced by Delenguaamano, group which I'm part of. 
sumário 
Um projeto arquitetônico, um monumento, um arquivo: progresso e memória

37

Monumento deslocado: perspectiva e narração

51

Álbum de Bronzes Artísticos Rebellato: trabalho, alegoria e ruína

75

Monumetria: o projeto

109

Trabalho inacabado, trabalho compartilhado: um relato

118

Bibliografía 

Según él, los actuales real visceralistas caminaban hacia atrás. ¿Cómo hacia atrás?, pregunté.

- De espaldas, mirando un punto pero alejándonos de él, en línea recta hacia lo desconocido.

Em Los Detectives Salvajes, de Roberto Bolaño 
introdução 


\section{Cidade e monumento}

Passagem, deslocamento, fragmentação, diluição, flexibilidade, fluidez, flutuação, volatilidade. Termos recorrentes no léxico teórico de diversas áreas do conhecimento e, em menor medida, presentes na linguagem cotidiana. Carregados da sensação de instabilidade socialmente disseminada, descrevem as dinâmicas de suas relaçóes. Portadores de valores positivantes quando celebram indiscriminadamente toda condição de instabilidade como possibilidade de mudança. Ameaçadores, quando pretendem destruir qualquer forma de continuidade. Localizam-se na escala de representação que é intrínseca à linguagem.

Os movimentos urbanos, com tudo o que têm de promessa e de violência, modificam constantemente as configurações espaciais e as relações que ali se estabelecem, em um processo de transformação que inevitavelmente gera contradições. Como um furação, que no seu passo desintegra e combina, destrói e relaciona. Nesse ambiente volátil, os procedimentos de construção são fragmentários e tendem a descontextualizar e justapor seus referentes. A célebre frase de Marx continua vigente: "Todas as relações fixas, enrijecidas, com seu travo de antigüidade e veneráveis preconceitos e opiniōes, foram banidas: todas as novas relaçôes se tornam antiquadas antes que cheguem a se ossificar. Tudo o que é sólido desmancha no ar, tudo o que é sagrado é profanado”.(1)

O dinamismo voraz de São Paulo é um paradigma de 'cidade selvagem'(2), como a chamara Lévi-Strauss. Uma confluência contrastante entre 'barbárie' e 'civilização'. Trata-se de uma cidade fundamentada na impaciência, que se desenvolve ansiosa, negando o que veio antes. Por um lado exibe uma força vital que se desenvolve com ímpeto, e por outro, um impulso auto-destrutivo paralisante. Numa conferência sobre a representação de São Paulo pelo cinema, Rubens Machado(3) comentou a dificuldade de imaginar esta cidade cinematograficamente, diferentemente de outras, que têm produzido imagens que as singularizam e as fazem reconhecíveis, como Paris, Nova York ou o Rio de Janeiro. Uma mostra dos dez postais mais vendidos em cada década do século XX em São Paulo, dificilmente repete a mesma imagem em décadas seguintes porque a cidade sempre alterou radicalmente sua fisionomia, destruindo a imagem de sua versão anterior. Uma constante de mudança a suspender continuamente quaisquer traços de continuidade.

O objeto de reflexão desta dissertação é o monumento a Ramos de Azevedo.(4) Este, em contraposição ao dinamismo urbano, tem um caráter essencialmente fixo e simbólico, com projeções fantasmagóricas que dificilmente comunicam através de sua linguagem original. Em suas origens foi uma construção prepotente, ligada a ideais progressistas da época, mas sua visibilidade e poder simbólico originais, com o tempo, tornaram-se opacos.

O monumento a Ramos de Azevedo faz parte de uma forma particular de se conceber esteticamente o tempo e o espaço para fins comemorativos. Monumentos comemorativos representam e transmitem memórias destacáveis de eventos ou personagens para a posterioridade. Em termos espaço-temporais, os monumentos comemorativos associam-se a algo grande, pesado, rígido e durável. Monumentalidade implica grandiosidade, permanência, além de um caráter extraordinário. 
Um monumento comemorativo é uma forma tradicional de conceber a história, que entende o tempo como sucessão linear e sincrônica de acontecimentos ordenados que mantém relaçôes hierárquicas claras entre si. É uma manifestação estética que dá corpo a essa concepção de história.

Essa linguagem essencialmente narrativa e pedagógica de monumento tem perdido relevância e eficiência como ativadora de memória e como produtora de signos de socialização. Paradoxalmente, passando por cima de sua pretensão de clareza, o simbolismo que representa resulta de difícil leitura.

Um monumento é portador de determinada cultura e testemunha de uma sociedade. Representa e revela valores. É veículo de distribuição de informação simbólica e sua capacidade comunicativa excede a vida da sociedade que o originou. Como signo, surge, tornase opaco, morre, e às vezes renasce. A trajetória histórica e sua relação com o espaço fazem dos monumentos indicadores de transformaçōes urbanas e culturais.

Esta dissertação parte das posibilidades interpretativas abertas pelo deslocamento do monumento a Ramos de Azevedo de seu lugar original, na Avenida Tiradentes, para a Cidade Universitária. Surge de uma experiência de estranhamento com seu novo contexto, que, incoerente, contrasta com os valores representados pelo monumento. Isto acontece porque na relação monumento/lugar há uma fratura sintática que se apresenta como estranheza visual, provocando um transtorno comunicativo.
Esta defasagem pode ser entendida como uma perturbação do sistema comunicativo original, cujo significado se dilui, ou como uma forma de comunicação que deixou de funcionar como tal. Interessa indagar aspectos afetados no seu modo de comunicação original. Em que consiste tal fratura? Perdeu-se seu significado, ou este apenas foi alterado?

Em termos de linguagem poderíamos assinalar o deslocamento do monumento como uma perda de discurso, e suas possibilidades na Cidade Universitária como incapacidade para construir proposições. $\mathrm{Na}$ área da lingüística, a fratura entre uma palavra e seu contexto gramatical e a incapacidade de relacioná-los é considerada uma perturbação da linguagem:

Nesse tipo de afasia, deficiente quanto ao contexto, e que poderia ser chamada de distúrbio da contigüidade, a extensão e a variedade das frases diminuem. As regras sintáticas, que organizam as palavras em unidades mais altas, perdem-se; esta perda, chamada de agramatismo, tem por resultado fazer a frase degenerar num simples 'monte de palavras' [...] A ordem das palavras se torna caótica; os vínculos de coordenação e subordinação gramatical, quer de concordância, quer de regência, dissolvem-se.(5)

No contexto da Cidade Universitária, o monumento é como um sujeito desprovido de funçôes gramaticais, incapacitado para a geração de discurso.

Qual o resultado da confluência e rivalidade entre lógicas espaçotemporais tão díspares, tais como a estabilidade enraizada e educadora dos monumentos comemorativos e a flutuação desconcertante da paisagem 
urbana? O monumento a Ramos de Azevedo é uma testemunha da fratura do simbolismo público em São Paulo. Existe materialmente mas é um símbolo mudo. Perdeu sua capacidade de legitimar o discurso oficial de uma época, de narrar o relato institucional que se impunha como núcleo identitário. Entendo-o como uma ruína que embora materialmente inteira, se encontra simbolicamente fragmentada.

O monumento, como qualquer obra de arte, demanda um entendimento objetivo, que o assuma como algo em si, com sua própria estrutura lógica e como parte de um sistema (o conjunto de obras do autor). Para além disso, como qualquer objeto cultural, material ou imaterial, sua lógica interna inter-atua e é afetada por um contexto e uma série de relações estabelecidas, ao adentrar fluxos narrativos específicos. As perguntas levantadas por esta dissertação se ocupam da relação do monumento com seus contextos e da possibilidade de significação destas confluências.

O monumento foi abordado enquanto memória, mediante reflexôes que indagam sobre sua especificidade na relação com seus espaços de apresentação e circulação. Interessa pensar como estes contextos transformam o significado do monumento e, ao mesmo tempo, como o monumento os transforma. E também como nos lembramos dessas mudanças. O deslocamento e suas repercussōes sobre questôes relacionadas à produção de memória também se colocam como uma problemática de representação.

$\mathrm{O}$ material que permitiu dirigir os questionamentos e mediante o qual se desenvolvem as propostas interpretativas é de registro, e inclui sobretudo fotografias. Revela-se também aí uma problemática de representação em relação a esses documentos.

\section{Registro e narração}

Ao atravessar a plana imensidão dos pampas argentinos, um inesperado acontecimento modificou a percepção do pintor viajante Johan Moritz Rugendas (1802-1858), célebre por sua produção prolífica (mais de 3000 obras), entre as quais se contam as ilustraçóes do clássico 'Viagem pitoresca ao interior do Brasil'. A esmagadora iminência de duas descargas elétricas impactaram-no repetidamente. Como se não bastasse, o segundo relâmpago fez com que o cavalo que o transportava corresse sem controle enquanto ele pendia de um dos estribos, causando uma deformação dramática em seu rosto:

A cara de Rugendas era uma massa inchada e ensangüentada, na testa havia um osso exposto, e lhe caíam tiras de pele por sobre os olhos. O nariz tinha perdido sua forma reconhecível, o nariz aquilino de Ausburg, e os lábios, dilacerados e retraídos, deixavam ver todos os dentes, milagrosamente intactos.(6)

As descargas afetaram o sistema nervoso do pintor modificando irreversivelmente sua percepção. Sua prática documental passou da aplicação comportada dos postulados da fisionomia a uma abordagem de tipo mais intuitivo. Do naturalismo à intuição.

Esta metáfora de transformação vem do território da ficção histórica, do livro 'Um acontecimento na vida do pintor viajante' do escritor argentino César Aira. Responde à incógnita da influência do contexto sobre a percepção do viajante, que no caso de Rugendas, provoca uma mudança pronunciada nas suas diretrizes estéticas. Aira 
não se interessa em diferenciar tematicamente o antes e o depois do encontro transformador. Sua ênfase se dirige à maneira de proceder do artista. Ou seja, concentra-se no "como" e não no "quê" da mudança. Refere-se aos dilemas da forma, de como representar realidades desconhecidas e contraditórias.

$\mathrm{Na}$ história das viagens figura uma grande quantidade de artistas, bem como na história da arte encontramos uma considerável parcela de viajantes. Jean Baptiste Debret (1768-1848) foi outro reconhecido artista viajante que passou pelo Brasil. Contemporâneo de Rugendas e ativo no novo mundo, chegou com a Missão Artística Francesa ao Rio de Janeiro, cidade na qual viveu desde 1816 até 1831, desenvolvendo uma abundante documentação visual.

Como documentaristas, Rugendas e Debret implementaram sistemas formais de representação destinados a suprir finalidades extraartísticas através da imagem. Tanto Rugendas quanto Debret trabalharam documentando o território e os costumes do novo mundo. Ainda que as necessidades científicas às quais respondia seu trabalho tenham influenciado temática e estilisticamente seus resultados, seria arbitrário simplificar sua arte a uma fórmula fisionômica sem variações.

Em 'Debret, o Neoclassicismo e a Escravidão', Rodrigo Naves interpreta os desenhos e aquarelas do artista - que considera suas obras mais significativas - como a busca de uma forma de representação que pudesse incorporar as particularidades e traços dos modos de socialização e da natureza Brasileira, estranhos à situação da França revolucionária e incongruentes com respeito a seus pressupostos neoclássicos. Esse embate entre realidade representada e forma de representação resultaria nestes trabalhos onde a ambigüidade das formas, seu aspecto fragmentário e sua fragilidade são característicos da situação local.(7)

O registro, como forma de comunicação, se estrutura a partir de uma série de traços opostos, que se complementam e se negam intercaladamente: objetividade/subjetividade, descrição/expressão, informação/narração. Nesse embate se põem em jogo e adquirem forma questóes relativas à representação.

As práticas de documentação têm na fotografia sua versão contemporânea mais recorrente. Não estão limitadas ao grau de especialização e domínio técnico que requeria de artistas como Rugendas ou Debret. Hoje em dia, as viagens fazem parte de um estilo de vida burguês generalizado e qualquer um que tenha uma câmera está habilitado a documentar sua travessia. Do documentarista expedicionário ao turista.

Uma cena contemporânea comum: um grupo de turistas tirando fotos. Estes viajantes documentam e depois narram suas aventuras desta forma. Decidem o que deve ser incluído e como, e assim o representam nas suas imagens. - Não vou embora sem uma foto sua neste parque! Fica mais para a direita um pouquinho, para a árvore $\mathrm{e}$ os passarinhos saírem.- Quando regressam da viagem e mostram as fotos à família e aos amigos, o que estes vêem não é nem a viagem nem os lugares visitados, senão uma narração da travessia. Como os artistas-documentaristas, os turistas derivam da figura do marinheiro comerciante, aquele representante arcaico do narrador viajante, que regressa de lugares desconhecidos cheio de histórias.

Ao se narrar um acontecimento, inevitavelmente se conduz à 
realidade a narrativa. O material narrativo é processado, delimitando e dando forma a uma infinidade de possibilidades. É inútil e suspeito afirmar que uma narração qualquer, independente da sua procedência, reproduz a realidade. Quando se narra, dá-se significado a uma sucessão de acontecimentos, e é nesse processo contínuo de transformação que se constrói realidade.

O registro fotográfico é uma forma de representação que mantém pulsante a tensão entre dado empírico e subjetividade narrativa. Por um lado existe a pretensão da objetividade científica, como se o que se mostrasse fosse o mundo em si, e não uma imagem do mundo mediada pela câmera fotográfica. Sua capacidade de reproduzir a realidade com verossimilhança apóia-se em aplicaçôes práticas de conhecimentos ópticos, químicos e mecânicos. Ou seja, a fotografia deriva de áreas específicas do conhecimento científico e produz imagens que traduzem tal conhecimento. Este tipo de saber profere enunciados denotativos que dependem de verificação ou falsificação a respeito de seus referentes. Um saber que exige provas e se apresenta como prova.

Por outro lado, qualquer fotografia é um canteiro de narração. Tocada pela mão da pessoa que a tirou, já se apresenta com a subjetividade de quem relata. As fotografias contam histórias mediante a sucessão de cenas e são tão simbólicas quanto qualquer outra imagem. O que têm para dizer depende de seu contexto narrativo e das funçōes relacionais que ali se estabelecem.

O registro fotográfico se tornou uma representação indispensável da obra de arte, apropriando-se de sua imagem. Além de servir como ferramenta de legitimação, parece ser o requisito para que a obra se torne real, por vezes ocupando um espaço de realidade mais real que da obra também foi apropriado e assumido como parte integrante da obra. É a condição de continuidade de qualquer obra efêmera, aquela que acontece numa fração de tempo e espaço delimitado, sem pretensões de duração prolongada para o objeto. Permanece na narração. O registro narra e atualiza a obra, é seu re-presentante legítimo no tempo.

Esta dissertação encara a seguinte pergunta: como o contexto narrativo influi sobre o trabalho? Além disso, pretende re-significar uma obra monumental procedendo por apropriação em diferentes níveis. O monumento a Ramos de Azevedo é seu ponto de partida e o registro, sua matéria prima. As interpretaçôes de seu deslocamento envolvem questionamentos sobre 'lugar' e 'meio', sendo o meio entendido também como lugar do trabalho e o lugar como meio do trabalho. Levando em conta que o monumento é encarado a partir de suas memórias, e entendendo a memória como o lugar onde estão as coisas que não estão, seu espaço seria o da representação de uma ausência que deixou impressões. Seus registros regulam estas impressões, lhes dão forma, duração e, claro, as reelaboram.

Não se pretende neutralidade no movimento que transita entre o trabalho e suas representações em forma de registro. Existe a vontade de refletir sobre esse movimento e essa formalização como lugar do trabalho. Nesse sentido, estas páginas se assumem como espaço gerador de experiência em si, e ao mesmo tempo, servem para articular outras experiências, espaços e tempos relacionados. Assinalam 
um monumento localizado em frente ao Liceu de Artes e Ofícios, na Cidade Universitária, em um álbum, em um projeto artístico e em uma série de obras de arte contemporânea expostas na Pinacoteca do Estado de São Paulo. É a estes espaços de representação aos quais desejo me dirigir e mediante sua manipulação, significar.

\section{Estrutura e metodologia}

Antes de encerrar estas anotações introdutórias, aclararei algumas questôes relativas ao caráter metodológico e formal do projeto. As reflexões aqui colocadas não pretendem apresentar retrospectivamente o pensamento nem a produção do autor, metodologia comumente usada em projetos de mestrado desenvolvidos na área de artes plásticas. Este projeto foi concebido e desenvolvido na sua totalidade no marco do mestrado, como uma resposta a minha experiência e relação com São Paulo. Não apresenta trabalhos anteriores de minha autoria, nem se articula como uma reflexão analítica (textual) a posteriori, sobre um conjunto de minha produção plástica. Neste caso, texto e produção plástica foram se desenvolvendo simultaneamente e ainda estão em processo. As reflexões aqui contidas serviram de fundamento para uma série de intervenções artísticas chamadas de 'Monumetria' e ao mesmo tempo se alimentaram e refletiram o processo de produção destas intervenções. Nesse sentido, de novo, estas páginas são assumidas como o 'lugar do trabalho', do projeto e do processo, e não como desenvolvimento posterior que traz e representa o trabalho que está em outro lugar. Obviamente, nada do que aqui se apresenta limita-se ao que aqui há. Mas esse "aqui" também contém o trabalho, não o enxerga de fora.

Quanto a sua estrutura, a dissertação se divide em cinco capítulos que se referem ao monumento a Ramos de Azevedo em contextos e momentos diferentes:

- Um projeto arquitetônico, um monumento, um arquivo: progresso e memória

- Monumento deslocado: perspectiva e narração

- Álbum de Bronzes Artísticos Rebellato: trabalho, alegoria e ruína

- Monumetria: o projeto

- Trabalho inacabado, trabalho compartilhado: um relato

Cada capítulo pode ser lido de maneira autônoma e se refere a uma faceta diferente do monumento. Mantêm vínculos e transformam-se entre si mas não supõem uma interdependência nem uma ordem específica de leitura.

'Um projeto arquitetônico, um monumento, um arquivo: progresso e memória', vincula três manifestaçôes ideológicas articuladas em torno da representação do progresso em São Paulo. Em que medida as fotografias de registro do escritório Ramos de Azevedo compartilham um tipo de linguagem com os edifícios que construíram e com o monumento que celebra seu artífice?

'Monumento deslocado: perspectiva e narração' oferece uma reflexão sobre o ponto de partida do projeto. Em que medida se transforma o monumento com seu traslado à Cidade Universitária? Esta 
pergunta se converte em outra: O que nos indica o monumento localizado na Cidade Universitária?

'Álbum de Bronzes Artísticos Rebellato: trabalho, alegoria e ruína' analisa a transformação do significado do monumento a Ramos de Azevedo, enquanto representado em um grupo de fotos que registra sua construção. Indaga sobre os efeitos da fragmentação do monumento interpretando-os como alegorização do trabalho.

'Monumetria: o projeto', é o projeto gráfico que deu origem e explica as intervenções da exposição artística com o mesmo nome, com inauguração no dia 7 de março de 2009 na Pinacoteca do Estado de São Paulo. Foi desenvolvido por DELENGUAAMANO, grupo formado pelos artistas Gilberto Mariotti, Santiago Reyes e por mim. Pode ser interpretado como um "retorno" do monumento ao seu lugar original, só que com as condiçôes transformadas: o antigo Liceu de Artes e Ofícios, antes dedicado ao ensino de uma educação técnica, hoje um museu que, entre outras atividades, promove e recebe exposições de arte contemporânea. O monumento, por sua vez, entra resignificado por quatro intervenções de arte contemporânea que usam material de registro como sua matéria prima.

Para terminar, 'Trabalho inacabado, trabalho compartilhado: um relato', faz uma reflexão sobre o processo de produção de Monumetria e as questôes levantadas pelo trabalho.

As seguintes páginas são uma leitura das idas e vindas do monumento a Ramos de Azevedo, a paradoxal itinerância de uma memória pesada.
Notas

1. MARX, Karl, in: BERMAN, Marshall, 'Tudo que é Sólido Desmancha no Ar: A Aventura da Modernidade', tradução de Carlos Felipe Moisés e Ana Maria L. Ioriatti, Companhia das Letras, São Paulo, 1986. pg. 21.

2. LÉVI-STRAUSS, Claude, 'Tristes Trópicos', tradução ao espanhol de Noelia Bastard, Eudeba -Editorial Universitaria de Buenos Aires-, Buenos Aires, 1973. pg. 83.

3. Prof. Dr. Rubens Luis Ribeiro Machado Junior, na palestra 'As Óticas de Representação e a Fisionomia da Metrópole nos Meios Audiovisuais', no marco do curso 'Intervençôes Públicas' oferecido pela ECA-USP em parceria com o Visual Art Program do MIT, Centro Cultural São Paulo, São Paulo, março 28 de 2008.

4. Obra de Galileo Emendabili -artista italiano emigrado a São Paulo em 1923-, o monumento a Ramos de Azevedo foi inaugurado em 25 de janeiro de 1934, em um local na Avenida Tiradentes, em frente do Liceu de Artes e Ofícios.

5. JAKOBSON, Roman, 'Lingüística e Comunicação', tradução de Izidoro Blikstein e José Paulo Paes, Editora Cultrix, São Paulo, 19? pg. 51.

6. AIRA, César, 'Um Acontecimento na Vida do Pintor-Viajante', Editora Nova Fronteira, Rio de Janeiro, 2007, pg. 53.

7. NAVES, Rodrigo, 'Debret, o Neoclassicismo e a Escravidão', in: 'A Forma Difícil', Atica, São Paulo, 1997. 

um projeto arquitetônico, um monumento, um arquivo: progresso e memória 
Fig. 1 Penitenciária de São Paulo: Entorno, Escritótio Ramos de Azevedo, Acervo da Ramos de Azevedo, Acervo c Biblioteca da FAU/USP

Fig. 2 Penitenciária de São Paulo: Construção, detalhe, Escritório Ramos de Azevedo, Acervo da Biblioteca da FAU/USP
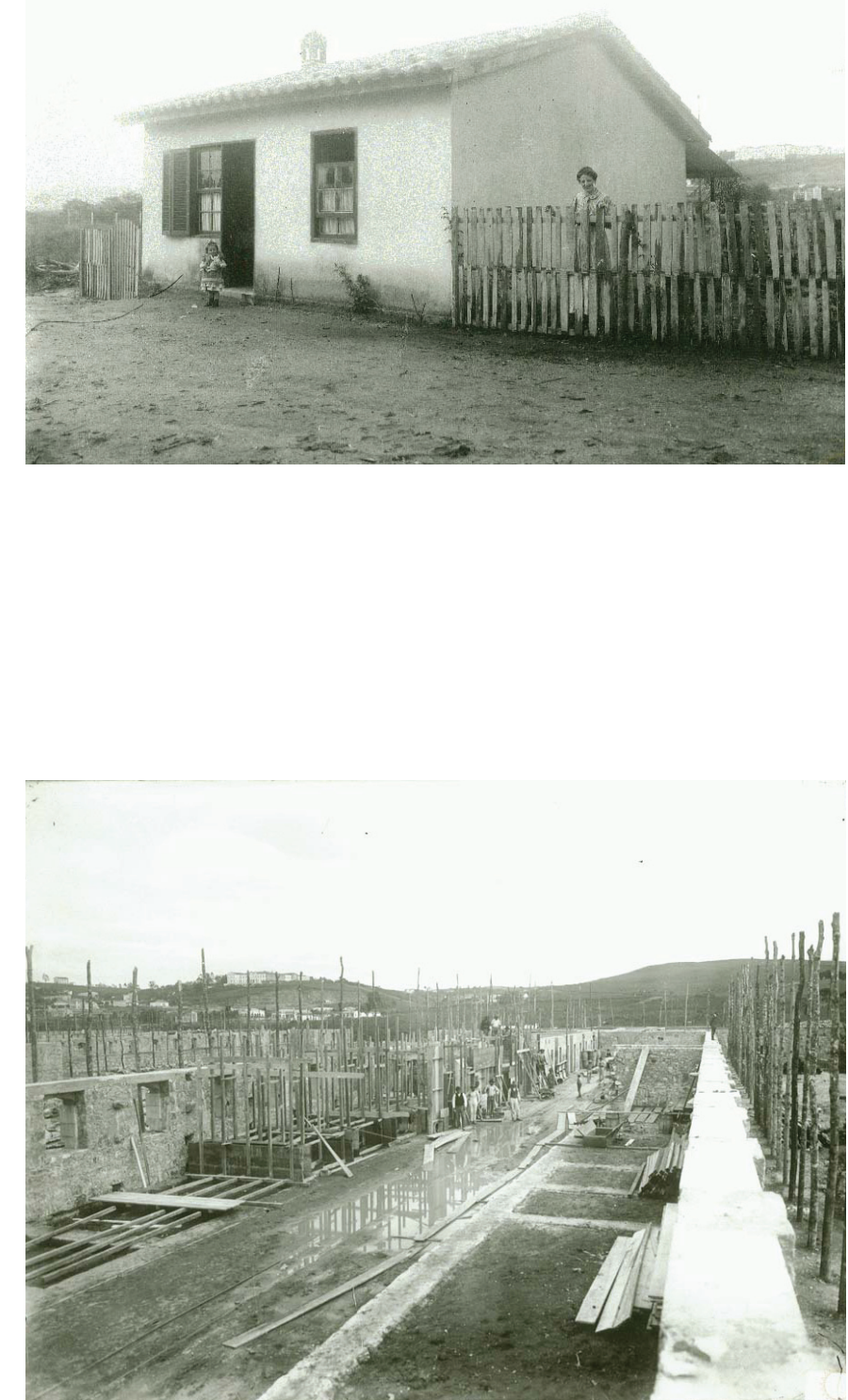

A magnitude do enterro do engenheiro-arquiteto Francisco de Paula Ramos de Azevedo (1851-1928) deu conta de sua importância simbólica para a sociedade paulista da época e já dava pistas da vontade dos seus conterrâneos de mantê-lo vivo no imaginário social de São Paulo.

Ramos de Azevedo foi um dos maiores responsáveis pelo novo direcionamento da fisionomia urbana de São Paulo de finais do século XIX e início do século XX, afastando-a dos parâmetros coloniais de edificação, introduzindo na cidade novas técnicas de construção e, sobretudo, novas maneiras de conceber, trabalhar e materializar o espaço urbano.

Durante as últimas décadas do século XIX e as primeiras do século XX, houve um aumento demográfico de proporçôes extraordinárias em São Paulo, impulsionado principalmente pela implantação de uma rede ferroviária no Estado, pelo êxodo da população rural para a capital, pelo fluxo de imigrantes estrangeiros e pela expansão da produção de café. Entre 1872 e 1900 a população aumentou 870\%.(1) O burgo colonial transformava-se em cidade industrial a passos agigantados. As construções, que eram feitas com o sistema da taipa de pilão, começaram a incorporar o tijolo. A demanda por novos parâmetros na produção de espaço gerada pela configuração social emergente, aliada à burguesia como classe social em processo de constituição e crescimento, encontrou respostas que se traduziram nos campos científico, técnico e industrial. 
Nesse panorama urbano em acelerado processo de mutação, Ramos de Azevedo inicia sua carreira depois de ter cursado Engenharia Civil, seguido de Engenharia e Arquitetura na Ėcole Spéciale du Genie Civil et dês Arts et Manufacures da Universidade de Gante na Bélgica. Suas propostas valeram-se de um corpo de idéias sobre a abordagem do projeto arquitetônico característico da situação dessa disciplina na época. Estas, por sua vez, mostravam-se permeáveis ao discurso predominante do momento, que tinha a tendência a sistematizar o conhecimento sob bases científicas e que, no campo da edificação, aproveitou-se das novas conquistas da arqueologia que propiciaram re-interpretaçōes de modelos tradicionais da arquitetura(2): "Classificou-se nas artes como se classificou na botânica e na zoologia. Leroy e, depois, tantos outros classificaram os edifícios e os estilo de todos os tempos. Prevalecia a idéia do tipo e da forma ideais para cada função".(3)

O estilo da arquitetura de Ramos de Azevedo é um representante do ecletismo, tendência que se valeu de modelos históricos anteriores, usando-os intercaladamente e com certa liberdade, dependendo das necessidades de cada projeto. Segundo Maria Cristina Wolff de Carvalho, no caso de Ramos de Azevedo, a noção de projeto surge fundamentada na função. $\mathrm{O}$ estilo escolhido dependia diretamente dessa função, do que fosse considerado correto dependendo da finalidade do projeto:

o projeto surge do conhecimento do 'tipo', da informação sobre as formas consagradas à função do edifício a ser projetado. A 'composição’ nada mais é que o trabalho de viabilizar o novo edifício dentro
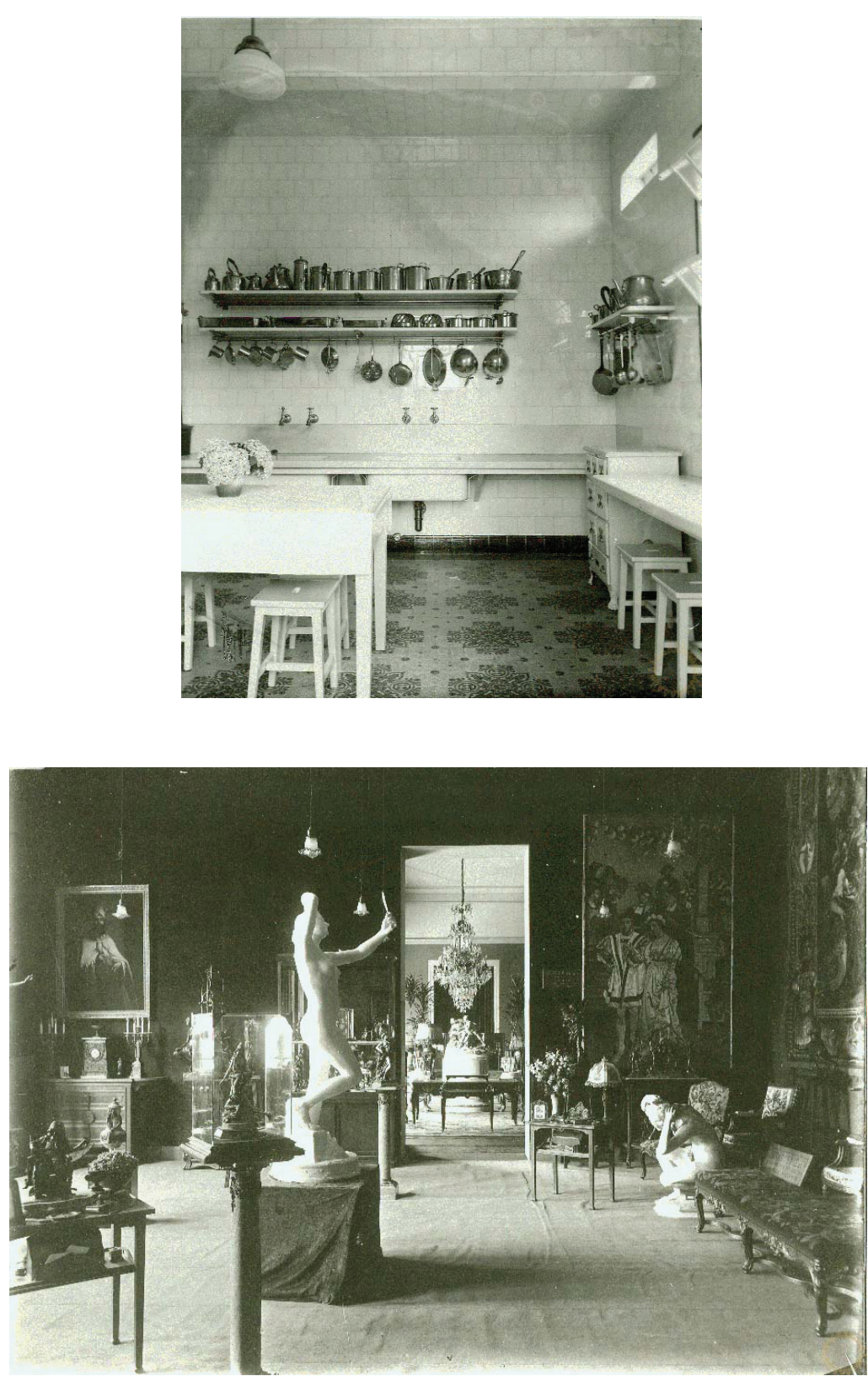

Fig. 3 Interiores: Cozinha, Acervo da Biblioteca da FAU/USP

Fig. 4 Interiores: Sala, Escritório Ramos de Azevedo, Acervo da Biblioteca da FAU/USP 
Fig. 5 Residência da Marquesa de Itu, Escritório Ramos de Azevedo, Biblioteca do Condephaat.
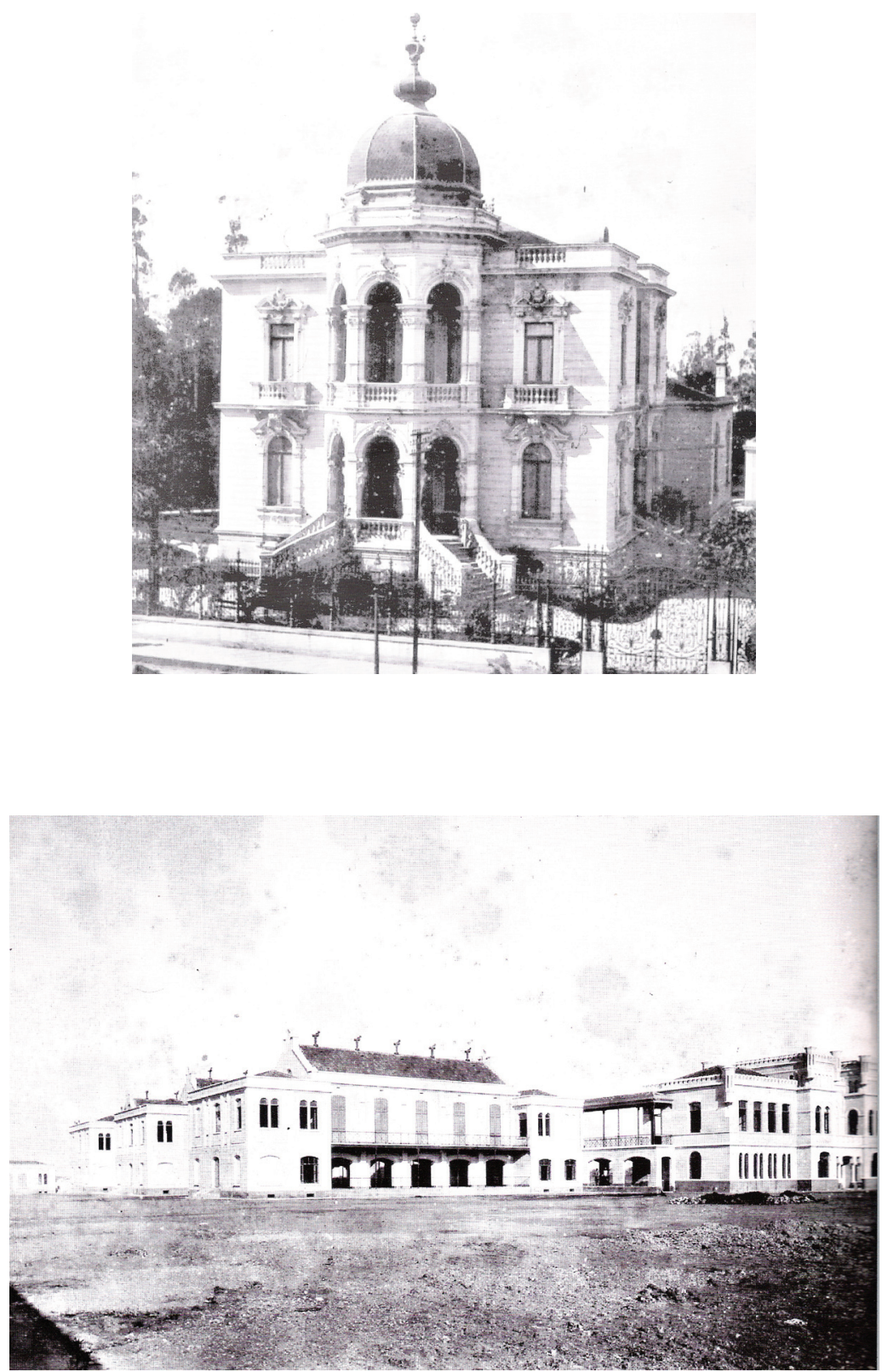

de determinados limites dados pelo programa, orçamento, terreno e o que possa representar uma barreira, a partir dos pressupostos das formas tidas como 'corretas', como que inerentes à função.(4)

Ainda segundo Wolff de Carvalho, duas determinantes significativas na definição desse perfil foram a influência da perspectiva dominante na Escola de Engenharia de Gante da época e o pensamento construtivo de Louis Cloquet (1849-1920) -Traité d'arquitecture-, o qual defendera a racionalização das formas mediante o conhecimento das regras construtivas. Os aspectos construtivos e as técnicas específicas envolvidas no erigir do edifício, seriam da maior importância para ele.

De fato, os projetos arquitetônicos elaborados por Ramos de Azevedo e seu escritório participaram ativamente na transformação dos parâmetros da edificação da cidade na época. Suas propostas acolheram novas opçôes provenientes do domínio da técnica e de concepçôes espaciais que enfocavam a importância da especificidade de cada projeto enquanto função, integrando na cidade o progresso industrial e enfatizando a atitude científica na atividade projetiva:

O padrão arquitetônico que Ramos de Azevedo trouxe de sua formação e que tratou de difundir -também por capacidade de articulação, promoção e trânsito entre as esferas de decisão- permitiu a São Paulo conhecer e se integrar aos programas e modelos mais caros ao século XIX. Hospitais, asilos, quartéis, escolas, jardins-de-infância, laboratórios, institutos, matadouros, edifícios públicos, e residenciais, constituem programas arquitetônicos que traduzem e respondem a um desejo de modernização. A arquitetura assume e materializa os progressos acumulados nos campos das ciências médicas, psiquiatria, 
educação, ciências sociais, saneamento, higiene, conforto e construção. A arquitetura se apresenta como parte do espírito investigador e científico de seu tempo.(5)

A forma do edifício devia se adequar ao caráter do projeto. Estava definida a priori e dependia da sua função dentro de um sistema maior, determinando as formas ideais para cada caso.

Ramos de Azevedo atuou decididamente na mudança de uma construção empírica para outra, mais preocupada com noções sistêmicas projetivas. Mas seu empreendimento e legado não se limitaram ao plano puramente arquitetônico, sendo sua gestão no âmbito educativo, como diretor do Liceu de Artes e Ofícios, como presidente do Instituto de Engenharia e como diretor, vice-diretor e professor da Escola Politécnica, da maior influência na concepção de espaço na cidade: "A primeira escola profissional de caráter industrial no Brasil funcionou junto ao Liceu, a partir de 1900, por iniciativa do arquiteto Ramos de Azevedo".(6)

As mudanças que o escritório de Ramos de Azevedo impulsionou na feição da nova cidade foram possíveis pela sua capacidade de articulação entre todos os momentos da construção. Seus projetos dependiam de mudanças estruturais na concepção de arquitetura. Como agente empreendedor, Ramos de Azevedo trouxe da Europa técnicas e formas de operar do campo da engenharia, foi sócio de companhias financeiras, forneceu o material especializado para suas construçōes (importadora de materiais), participou da industrialização dos produtos (teve uma marmoraria e uma extratora de cal), formou especialistas (engenheiros da Escola Politécnica) e mão de obra competente (Liceu

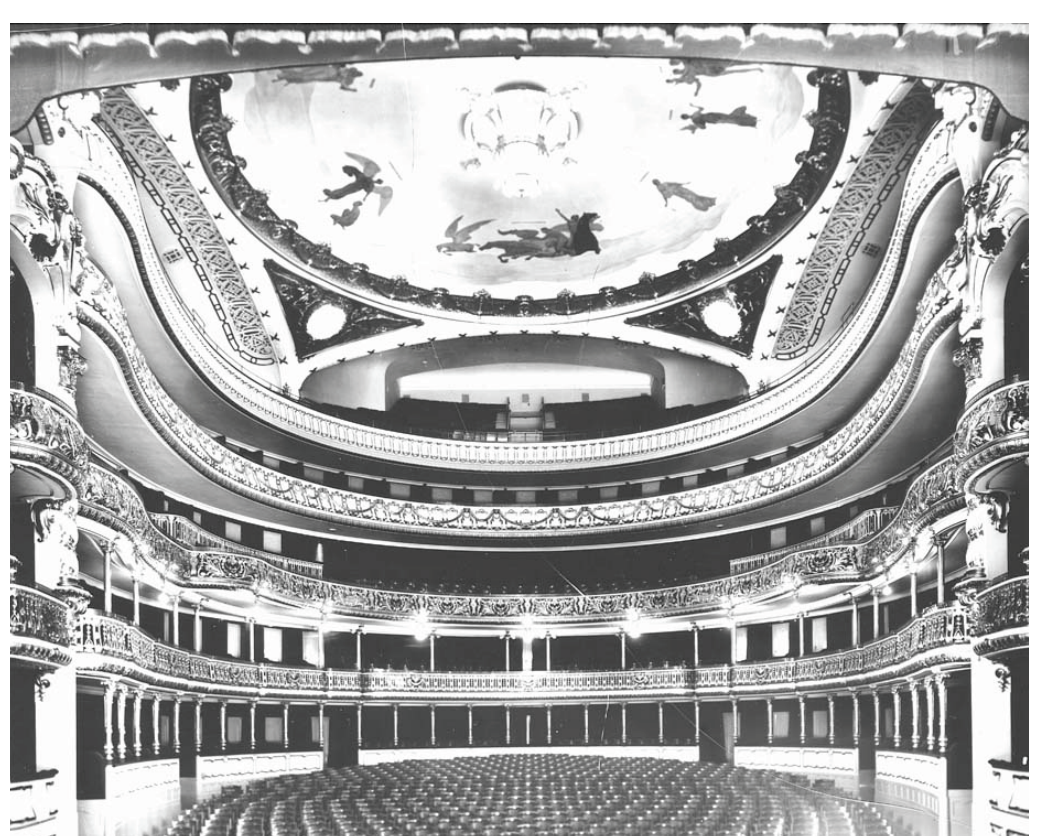

29

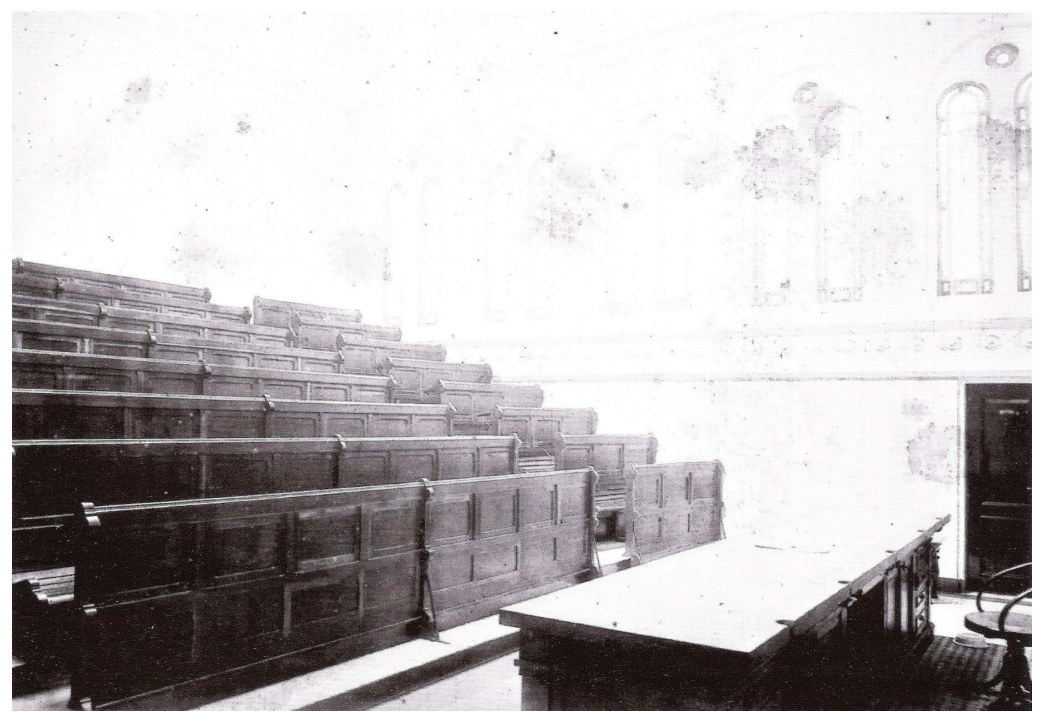

Fig. 8 Auditório do edifício do Laboratório da Escola Politécnica, Escritório Ramos de Azevedo, Biblioteca do Condephaat 
Fig. 9 Membros do Comitê Pró-Monumento a Ramos de Azevedo, 1934. Foto: Hugo Zanella. Arquivo Fiammetta Emendabili.

Fig. 10 Membros do Comitê Pró-Monumento a Ramos de Azevedo, s.d. Foto: Hugo Zanella. Arquivo: Fiammetta Emendabili
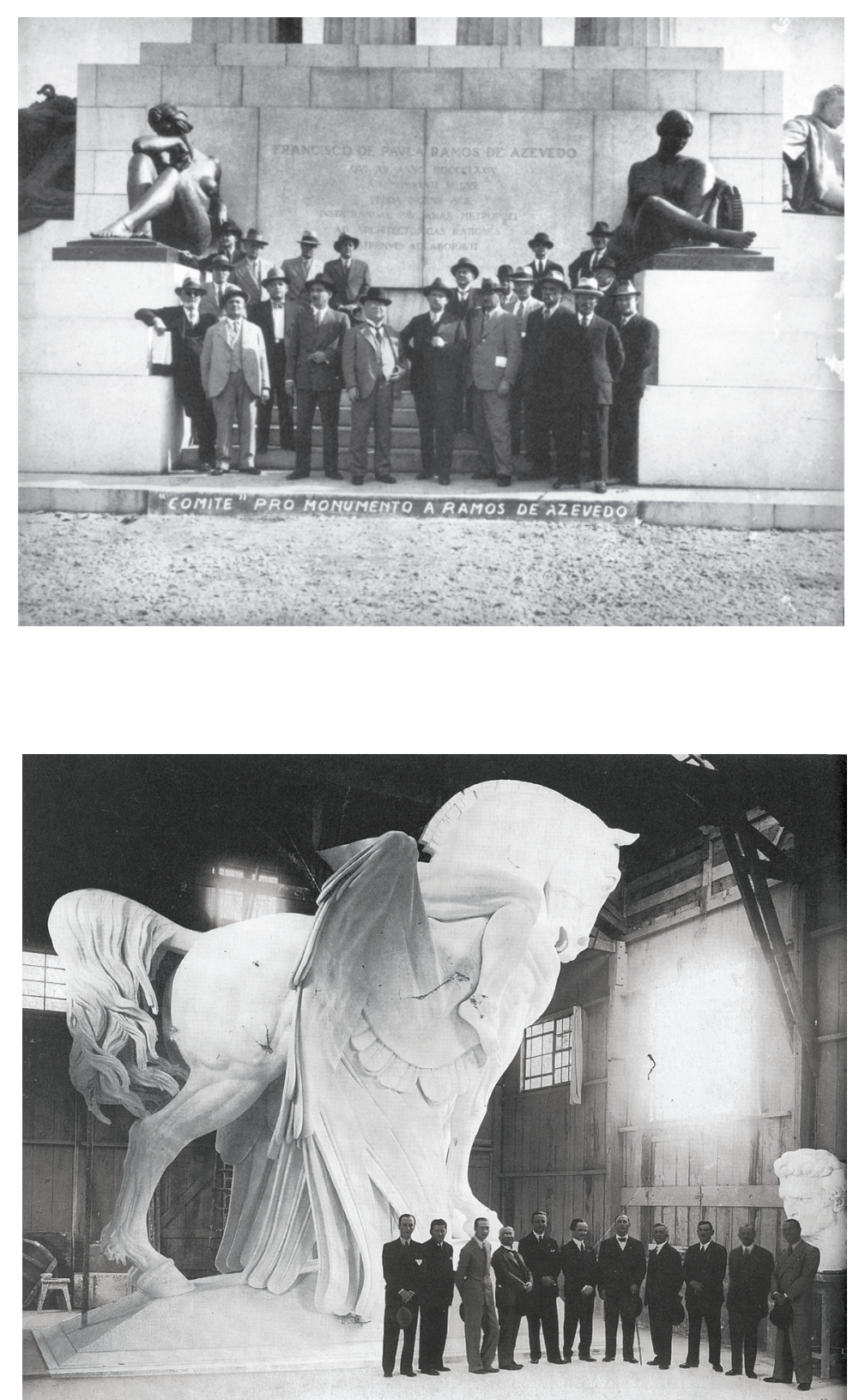

de Artes e Ofícios) e participou da vida pública da cidade. Todas estas instâncias foram necessárias para realizar o tipo de arquitetura em que seu escritório atuava.

2

Depois da morte de Ramos de Azevedo, ocorrida em 12 de junho de 1928, foi constituído o Comitê Pró-Monumento a Ramos de Azevedo, com a finalidade de promover o reconhecimento de sua memória. Abriu-se um concurso público para escolher o projeto mais de acordo com as intenções da comemoração e que traduzisse a relevância histórico-social e o perfil individual do homenageado. O projeto vencedor foi o de um artista italiano, Galileo Emendabili, emigrado para São Paulo em 1923. Ele realizou um número considerável de esculturas públicas, das quais se destaca o Monumento a Ramos de Azevedo. Além deste, os monumentos a Pereira Barreto e ao Soldado Constitucionalista estão entre seus trabalhos mais reconhecidos.

O homenageado era um ótimo representante da mentalidade liberal progressista do momento. Seu caráter empreendedor, sua laboriosidade, sua individualidade criadora, seus ideais laicos, seu legado de modernização, faziam de Ramos de Azevedo um exemplo perfeito da ideologia da burguesia emergente (da qual fazia parte) em busca da legitimação de seu discurso.

Essa busca estava estreitamente vinculada ao crescimento econômico paulistano e ao anseio de sua elite pelo reconhecimento no cenário político-cultural nacional como nova centralidade, diferenciando-se das 
outras regiōes do país. Sua identidade particular teria raízes na figura mítica do Bandeirante, e Ramos seria sua representação atual.

A iniciativa da construção do monumento teve uma recepção positiva e uma subseqüente discussão pública que mostrava a concordância em torno do fato de Ramos de Azevedo merecer tão altas celebrações. Com uma ampla visibilidade e interesse dados pela imprensa, um grande número de projetos inscritos no concurso e uma considerável quantia de doaçōes efetuadas por colegas, amigos e até por trabalhadores subalternos do arquiteto para viabilizar economicamente o projeto, a iniciativa foi acolhida pela sociedade paulista. A vontade da elite de legitimar simbolicamente seu discurso, estabelecendo-o como memória oficial foi realizável pela ressonância que conseguiu na sociedade, acolhendo o progresso como signo identitário:

Fator determinante da construção de um monumento como aquele dedicado a Ramos de Azevedo é a vontade de memória de um grupo que, no final da década de 20 , se funde com a vontade de memória de uma comunidade. Esta fusão [...] não é ditada pelo acaso ou por uma determinação puramente emocional. Deriva antes de um projeto ideológico preciso, articulado em volta da noção de progresso, isto é, em volta de um tempo dividido em duas metades, um 'antes' e um 'depois', dentro do qual Ramos de Azevedo exerce o papel mítico do fundador. Integralmente voltada para a projeção no futuro, São Paulo elege o arquiteto como símbolo de sua transformação, como modelo originário de uma mentalidade empreendedora, capaz de transformar, em poucos decênios, a pacata cidade de província numa metrópole moderna e vibrante.(7)

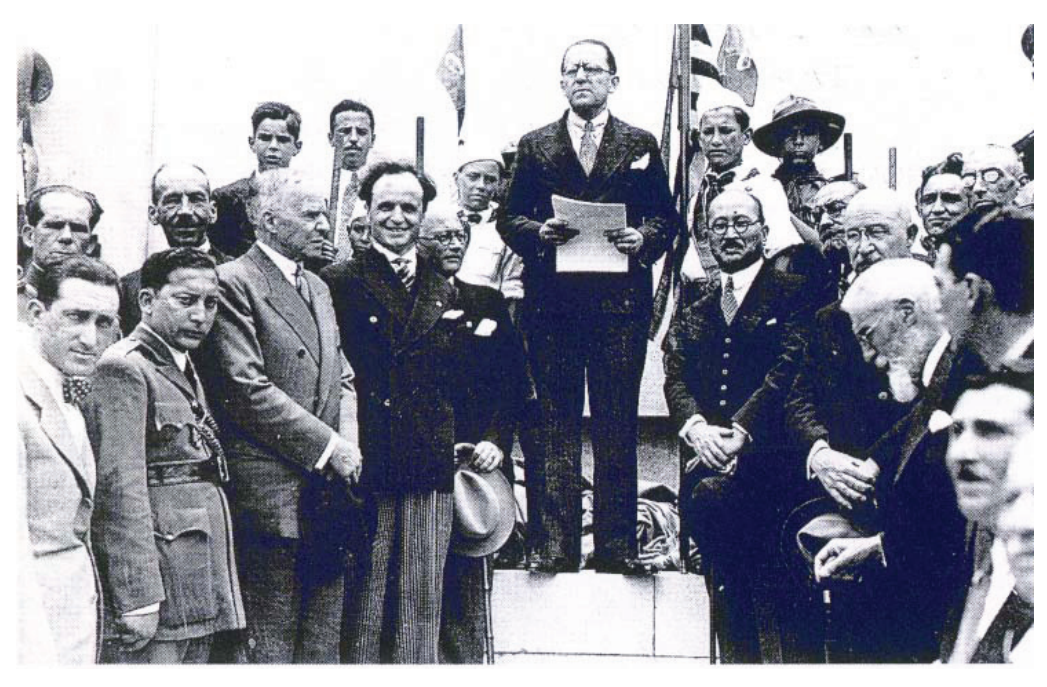

Fig. 11 Flagrantes da inauguração do monumento a Ramos de Azevedo, 25 de jan. 1934. Autor desconhecido. Arquivo: Fiammetta Emendabili

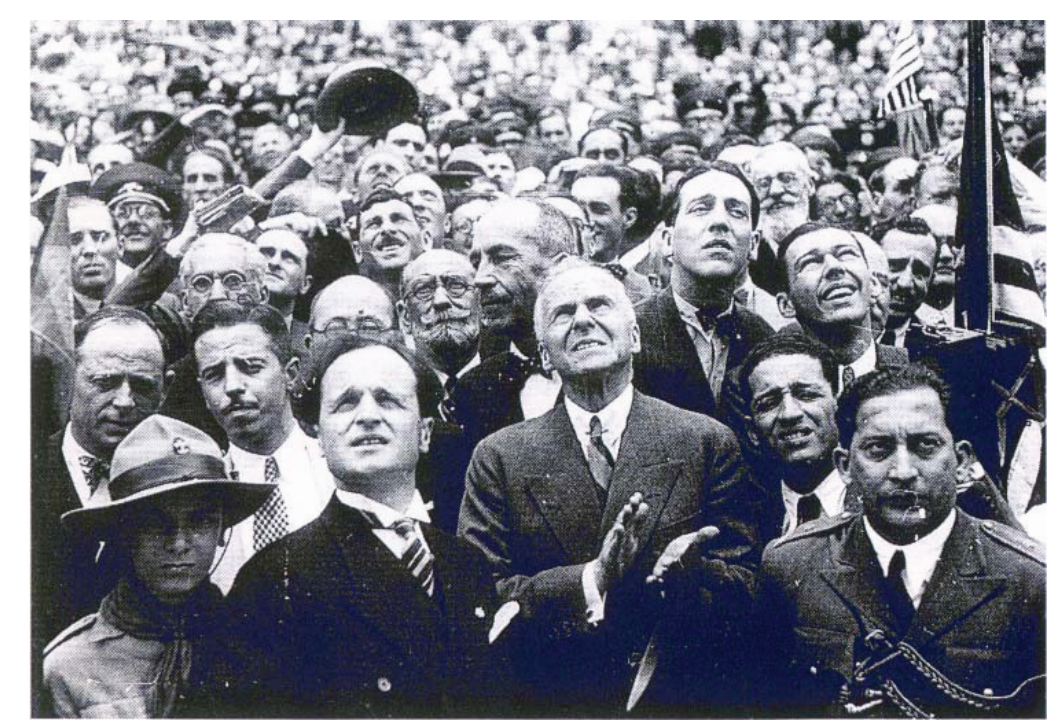

Fig. 12 Flagrantes da inauguração do monumento a Ramo de Azevedo, 25 de jan. 1934. Autor desconhecido. Arquivo: Fiammetta Emendabili 
Fig. 13 Penitenciária de São Paulo: Interior, Escritório Ramos de Azevedo, Acervo da Ramos de Azevedo, Acervo
Biblioteca da FAU/USP.

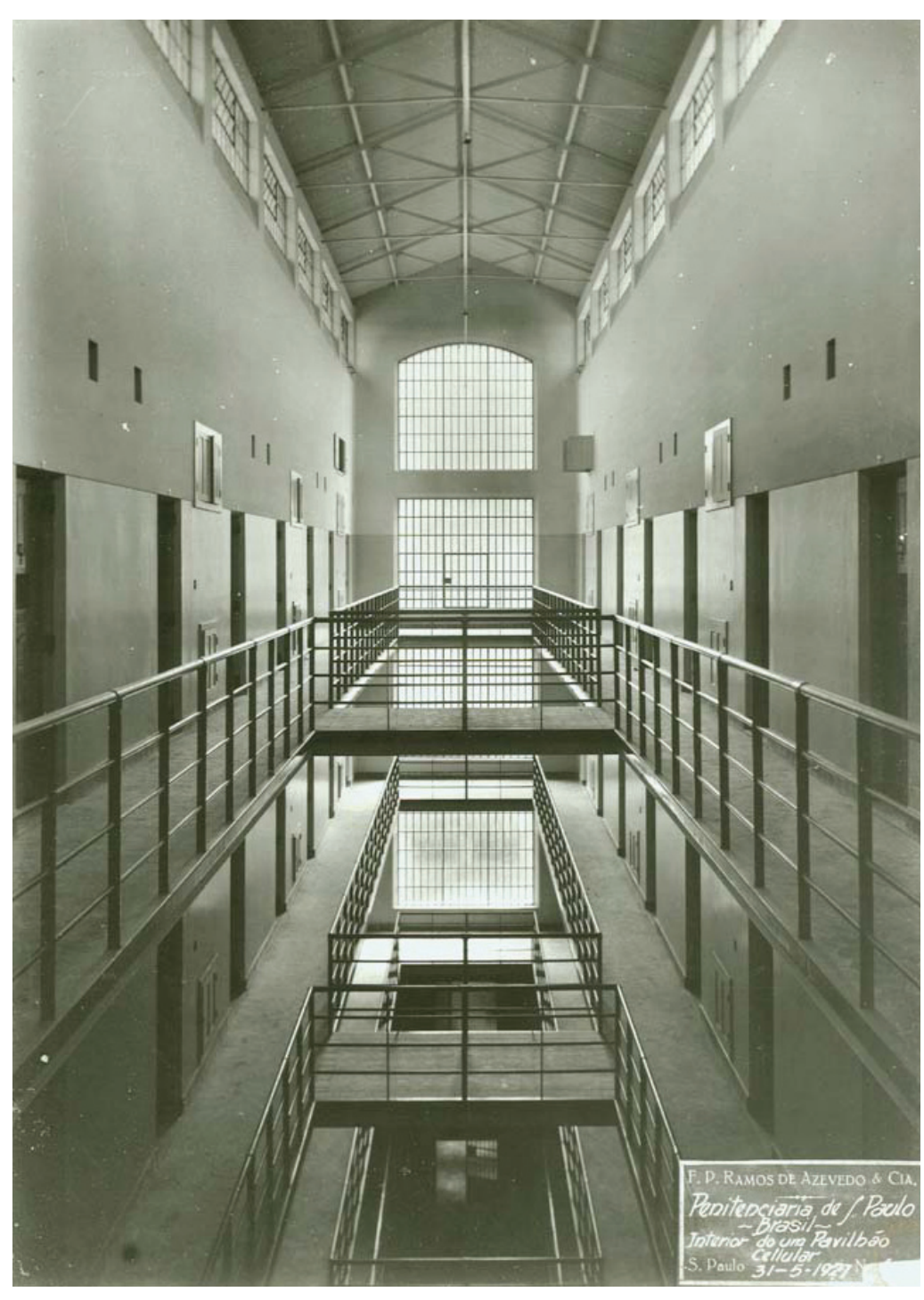

A construção do Monumento a Ramos de Azevedo manifesta uma decisão política que, mediante a projeção simbólica dos ideais de um grupo de pessoas, marcou um momento histórico específico no território e materializou uma visão precisa e determinada de sociedade. Esse discurso encontrou na figura emblemática de Ramos de Azevedo o representante ideal dos seus interesses, devido a seu legado arquitetônico e personalidade que eram encarnações exemplares dessa ideologia.

\section{3}

Dentro da cultura burguesa o projeto fotográfico, bem desde o começo, tem sido identificado não só com o sonho de uma linguagem universal, mas também com o estabelecimento de arquivos globais e repositórios de acordo com modelos oferecidos por bibliotecas, enciclopédias, jardins zoológicos e botânicos, museus, fichas policiais e bancos... Na verdade, sua base filosófica se encontra em um empirismo agressivo, voltado a alcançar um inventário universal de aparências. Projetos de arquivo tipicamente manifestam um desejo compulsivo por completude, uma fé em uma coerência final imposta pela simples quantidade de aquisiçōes. Na prática, o conhecimento deste tipo só pode ser organizado de acordo com meios burocráticos.(8)

O escritório de Ramos de Azevedo gerou um arquivo repositório composto pelos registros das construçōes que projetou, e que hoje em dia se encontra hospedado na biblioteca do Condephaat e no Acervo da Faculdade de Arquitetura e Urbanismo da Universidade de São Paulo FAU-USP. A maioria das fotos usadas neste capítulo estão nesses arquivos. Que informação sobre modos de representação 
pode ser extraída destas imagens tomadas individualmente e em que medida estão em consonância ou pertencem a um sistema discursivo?

Gostaria de assinalar a correspondência e reverberação entre estes registros, o tipo de arquitetura que representam e o monumento a Ramos de Azevedo em relação a uma forma particular de conceber a memória. Verifica-se sua conexão por serem geradores de uma espacialidade e uma temporalidade similar, assim como em sua relação com um corpus maior que os articula como fragmentos interdependentes de um sistema discursivo.

Rosalind Krauss (1941-) identificou o espaço discursivo da fotografia no sistema do arquivo que, como no caso da superfície da parede, que seria a representação mais básica do valor de 'exposição' -vetor fundamental para o discurso estético do século XIX, manifestado em museus, galerias, salões oficiais, etc.-, seria a 'condição de realidade' dos enunciados fotográficos.(9) Ou nas palavras de Foucault, de cujo modelo arqueológico de investigação Krauss parte, o sistema do arquivo seria definido "como o grupo de regras que caracteriza uma prática discursiva"(10), as condições segundo as quais se exerce esta prática.

Krauss ressalta a pertinência de examinar o sistema-arquivo de forma arqueológica e entender a fotografia do século XIX e começos do século XX en- quanto expressão deste campo discursivo. Desenvolve seu argumento em torno da obra de Atget (umas 10.000 fotografias) que, segundo ela, para ser interpretada em sua totalidade, deve ser entendida em relação à forma catálogo. Cada uma das 10.000 placas de Atget, tem um número que cumpria a função de sistematizar um catálogo de temas topográficos que pretendia documentar diversas realidades e abastecer diferentes coleçôes históricas, tais como Monu-

O sistema de códigos aplicado por Atget às suas imagens deriva do catálogo das bibliotecas e das coleçôes topográficas para as quais trabalhava. Seus temas eram frequentemente estandardizados, porque eram ditados pelas categorias estabelecidas da documentação histórica e topográfica. A razão pela qual bom número de imagens de rua se parece curiosamente às fotografias de Charles Marville tiradas meio século antes, é que tanto as primeiras como as segundas foram produzidas de acordo com o mesmo plano diretor de documentação.(11)

É essa mesma pulsão documental que está por trás das fotos do arquivo de Ramos de Azevedo, que as faz peças de um sistema de organização cujo leitmotiv está na acumulação de aparências e cujo produto pretende ser preservado no tempo. Este sistema de organização não está isolado. Reflete uma prática discursiva mais abrangente e o empreendimento histórico de um grupo social determinado, que se valeu da sistematização e catalogação do conhecimento sobre fundamentos empíricos vindos do campo da ciência para infundir noções de progresso na cidade.

O tipo de arquitetura que o escritório de Ramos de Azevedo construiu pôs em prática essa tendência documental do arquivo como ferramenta constitutiva de sua forma de abordar o projeto arquitetônico. Este, como apontei anteriormente, se valeu do tipo de informação que as práticas de classificação permitiam. O padrão arquitetônico que o escritório de Ramos de Azevedo praticava dependia do conhecimento do 'tipo', das formas ideais para cada projeto. As formas e os estilos 
Fig. 14 Penitenciária de São Paulo: Vista aérea, Escritório Ramos de Azevedo, Acervo da Biblioteca da FAU/USP.

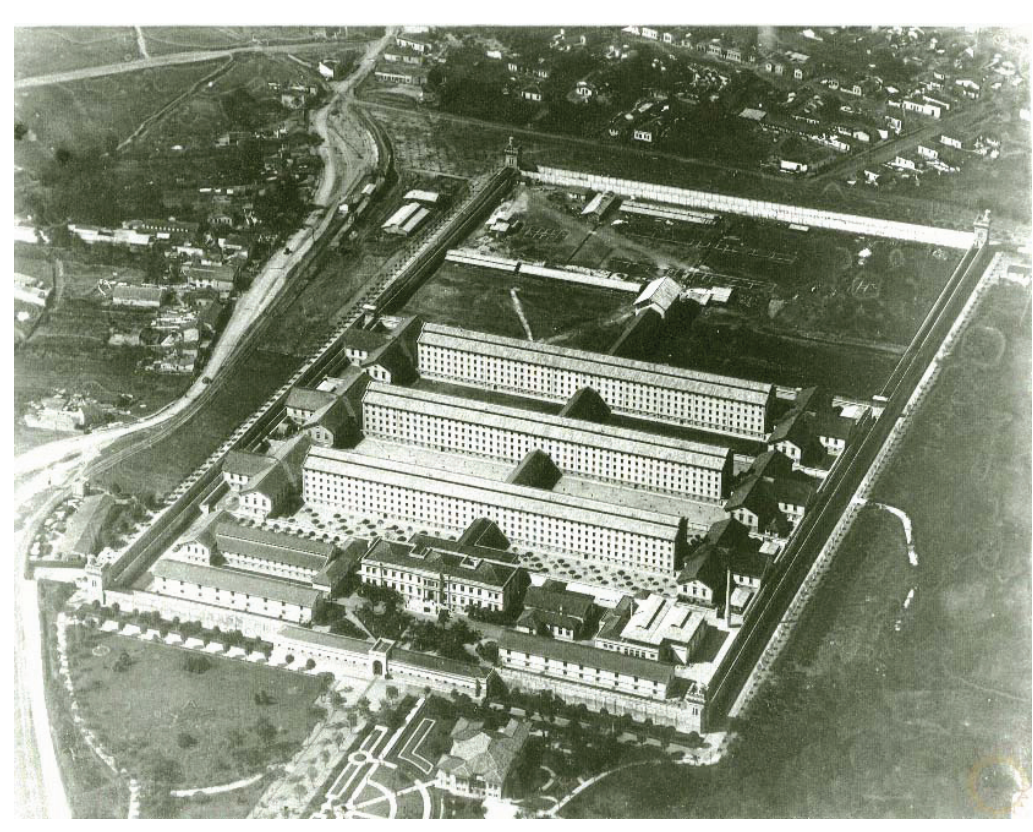

dos edifícios dependiam da função do projeto e eram determinados a priori simulando as formas históricas entendidas como ideais para cada função.

O registro fotográfico entendido como função de um arquivo pretende proporcionar uma visão total do objeto representado e do grupo ao qual este objeto pertenceria. É um olhar abarcador movido pelo desejo de completude. Enquanto forma comunicativa, se apresenta com a objetividade própria do dado empírico, como informação meramente descritiva que não toca seu objeto de representação. Pretende ser um filtro neutro desprovido de sujeito, que oferece seu objeto de representação de forma clara, transparente e total. Ou seja, não estaria representando seu objeto, estaria o apresentando sem mediação.

Os registros fotográficos do arquivo do escritório de Ramos de Azevedo cumpriam uma função prática dentro da concepção de projeto arquitetônico que produziram. Serviam para controlar as etapas de cada projeto e aprimorar seu sistema construtivo de um projeto para o outro.

Além da sua função prática, os registros cumprem uma função histórica. Permanecem arquivados como documentos e proporcionam um tipo de memória. Este tipo de memória carrega consigo os preceitos da forma que a comunica. Apresenta-se como uma lembrança objetiva, transparente e total, dando a impressão de ser uma verdade materializada, capaz de produzir uma memória sem intenção e sem perda. É um ponto de vista positivista que interpreta o lugar da história como sendo um espaço homogêneo. Seu procedimento é aditivo 
e serve a uma ideologia progressista que caminha em linha reta e que precisa deste tipo de registro como parte integrante de seu discurso.

Como todo discurso, para que seja levado à exercer efeitos públicos sobre a formação do saber, necessita de formas de legitimação que o validem como 'realidade'. Deve ser comunicado de maneira eficiente à sociedade onde pretende se inserir.

Neste ponto, o monumento a Ramos de Azevedo entra em cena. Este foi usado para legitimar o discurso progressista da burguesia emergente de São Paulo, na forma de monumento. Serviu como veículo comunicativo que narrava de forma épica a história triunfal de São Paulo de final do século XIX e começo do século XX, onde Ramos de Azevedo é o personagem principal, coberto por uma aura mítica, que dirige a cidade em direção ao progresso.

A forma de representação do monumento combina estilos narrativos e cenográficos próprios da dramaturgia, com modos de representação oriundos do campo da ciência. Sua linguagem tem momentos em que a forma da arquitetura praticada por Ramos de Azevedo e o tipo de registro produzido pelo seu escritório confluem. Em um nível mais narrativo poderíamos citar como exemplos: a simulação cenográfica de épocas passadas, através do uso indiscriminado de estilos históricos a pretexto de ecletismo e o recurso neoclássico praticado no monumento, que representa a figura humana tendo por referência os cânones clássicos. Ou ainda as cenas construídas nas fotos de registro do escritório de Ramos de Azevedo onde personagens humanos determinam a escala monumental das edificações onde estão (Fig. 16).
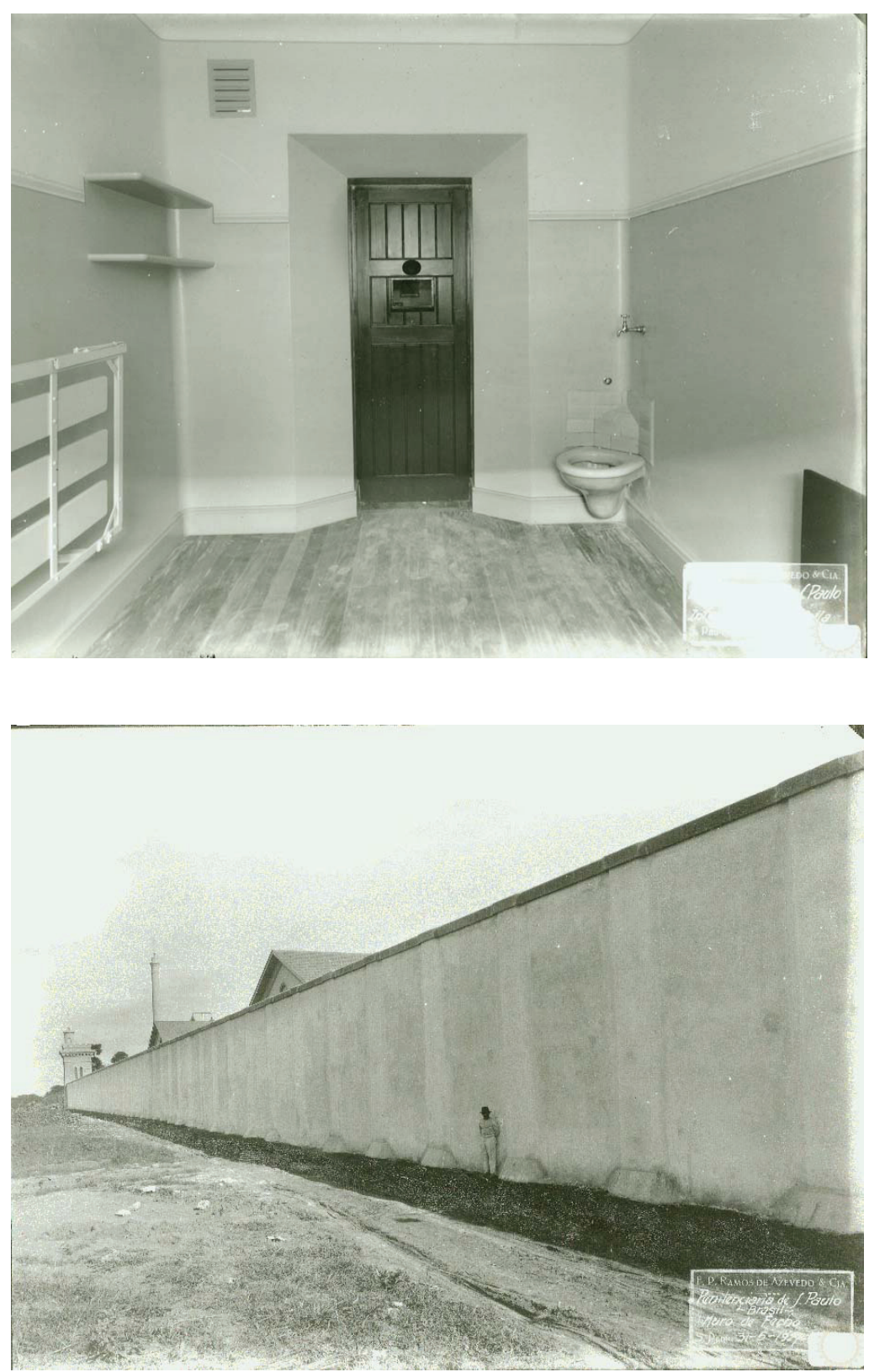
Ramos de Azevedo, Acervo da
Fig. 16 Penitenciária de

São Paulo: Muro, Escritório Biblioteca da FAU/USP.

Fig. 15 Penitenciária de São Ramos de Azevedo, Acervo d Biblioteca da FAU/USP

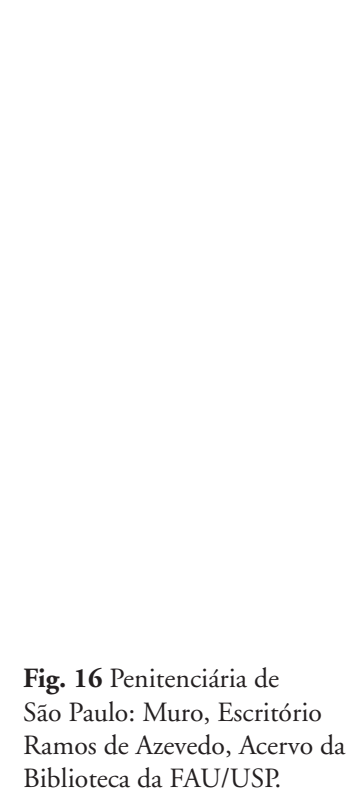
Paulo: Interior, Escritório 
Enquanto conhecimento científico, edifícios, registros e monumento fazem uso das regras ordenadoras da perspectiva para construir imagem.(12) Nesta forma compositiva se estrutura e define seu sujeito/ usuário/espectador, virtualizando o uso do espaço que provêem e sua experiência. É um ponto de vista que idealiza, homogeniza e controla o sujeito. Como no registro da cela do 'prisioneiro virtual' (Fig. 15), que define e controla todas suas possibilidades dentro desse espaço: ele pode usar o banheiro, pode possuir uma pequena quantidade de objetos, os quais seriam colocados sobre as duas prateleiras, tem acesso a uma corrente de água, etc.

Com a remoção do monumento a Ramos de Azevedo do seu lugar original, algumas destas formas progressistas de gerar memória foram truncadas.

\section{Notas}

1. SEGAWA, Hugo, 'Arquiteturas no Brasil: 1900-1990', Editora da Universidade de São Paulo, São Paulo, 1998, pg. 19.

2. WOLFF DE CARVALHO, Maria Cristina, 'Ramos de Azevedo', Editora da Universidade de São Paulo, São Paulo, 2000, pg. 355, 362.

3. WOLFF DE CARVALHO, Op. Cit., pg. 356.

4. WOLFF DE CARVALHO, Op. Cit., pg. 102.
5. WOlFF DE CARVALHO, Op. Cit., pg. 364.

6. SALGADO LOUREIRO, Maria Amélia, 'A Evolução da Casa Paulistana e a Arquitetura de Ramos de Azevedo', Voz do Oeste, São Paulo, 1981, pg. 49.

7. FABRIS, Annateresa, 'Monumento a Ramos de Azevedo: do Concurso ao Exílio’, Mercado de Letras, Campinas, 1997, pg. 52.

8. SEKULA, Alan, 'Photography Between Labor and Capital', in: 'Mining Photographs and Other Pictures: A Selection from the Negative Archives of Shelddon Studio, Glace Bay, Cape Breton', Press of the Nova Scotia College of Art and Design, Nova Scotia, 1983. (Tradução minha)

9. KRAUSS, Rosalind, 'Photography's Discursive Spaces', in: 'The Originality of the Avant-Garde and Other Modernist Myths', The MIT Press, Cambridge, Massachusetts, London, 1985. (Tradução minha)

10. FOUCAULT, Michel, 'The Historical a priori and the Archive', in: 'The Archive', editado por Charles Merewether, Whitechapel, London, The MIT Press, Cambridge, Massachusetts, 2006, pg. 27. (Tradução minha)

11. KRAUSS, Op. Cit., pg. 147.

12. Em relação ao uso da perspectiva no monumento ver capítulo: 'Monumento Deslocado: Perspectiva e Narração'. 
monumento deslocado: perspectiva e narração 


\section{1}

$\mathrm{Na}$ primeira vez que o vi, a imagem se formou rapidamente. Estava em um dos ônibus universitários que fazem o circuito pelo campus da USP, quando me surpreenderam sua magnitude e aparição repentina, como que saído do nada. Um monumento instantâneo, pensei. Foi essa a impressão que permaneceu em minha memória. Retive a imagem do cavalo e das colunas dóricas. O ônibus seguiu adiante.

O segundo encontro foi diferente. Cheguei caminhando e lá estava, rodeado de grama, com a área baixa da base coberta, fazendo um bonito contraste com o branco da pedra. Também havia pequenos arbustos e algumas árvores suntuosas em volta. Cheguei por uma avenida que leva ao seu encontro e o envolve, o circunda e volta em linha reta, delimitando seu perímetro. O motorista ou passageiro de um veículo que circula pela avenida se surpreende quando o monumento aparece no seu espectro visual, sem se anunciar. Nessas circunstancias é uma aparição.

Para o pedestre a relação é outra. $\mathrm{O}$ tempo da caminhada me permitiu ver a Escola Politécnica, o Instituto de Eletrotécnica e o Instituto de Pesquisas Tecnológicas, construçôes que, apesar de próximas do monumento, pouco ou nada dialogam com ele. Este vem de um lugar idílico e não é tocado pelo tempo, enquanto a escola e os institutos são espaços mundanos de conhecimento aplicado. $\mathrm{O}$ monumento supera as outras construções em altura. As árvores também não igualam seu porte, só o toca o azul do céu.
$\mathrm{Na}$ medida em que me aproximava, as figuras cresciam e engoliam o ambiente. De perto era gigantesco. Sua linguagem clássica também. A desproporção desse gesto nesse lugar me pareceu improvável. $\mathrm{O}$ cavaleiro nu sustentando a figura de um anjo. $\mathrm{O}$ cavalo com asas. $\mathrm{O}$ granito branco. As escadas que o atravessavam lateralmente, que deram-me a impressão de serem o caminho para uma espécie de palco atemporal, um lugar onde tinham desfilado heróis e grandes oradores.

À frente, um homem em posição de repouso contemplando a paisagem, sentado e vestindo roupas formais. Segurando sobre suas pernas o que parecia ser uma planta arquitetônica. O que planeja este homem? Talvez o que está atrás dele, ou o que está a sua volta. Sua postura me pareceu nostálgica. Talvez não planeje, apenas contemple.

$\mathrm{Na}$ parte posterior, um grupo de homens nus empurrando para frente uma espécie de bloco. Em cada costado da base duas mulheres, todas muito parecidas, entre si, como se parecem irmãs, e de uma beleza clássica que atravessou séculos para lhes dar a aparência. Foram as únicas figuras que quis ver de perto. O que as diferenciava era apenas seu instrumento e algumas evidências de vida, rastros de pintura, garrafas quebradas, sinais de fogo. Uma segurava uma paleta. Depois fiquei sabendo que também deveria ter possuído pinceis, que seguramente foram vendidos como bronze para fundir. A que está do seu lado não segurava nada, mas deveria ter portado um compasso, seguramente também vendido como matéria prima. As do outro lado seguravam uma engrenagem e um martelo. Por sua aparência, era difícil pensar que aquelas figuras pudessem usar seus instrumentos de forma prática. Sua função era exibí-los. 
Interpretei o grupo das oito colunas dóricas modernizadas que unem a base com a parte superior, como uma representação do passar dos anos, nossa comunicação com tempos pretéritos quando os homens construíam para sempre. Assim imagino as ruínas clássicas. Senti-me percorrendo um simulacro de ruína grega, ou a xérox de uma obra de arte universal. No topo da construção, o cavaleiro nu montando seu cavalo alado. A imagem me pareceu muito confiante e decidida. Depois ficaria sabendo que o anjo na mão do cavaleiro é sua mensagem: a Vitória.

As primeiras fotos que vi do monumento(1) me pareceram contrárias à experiência de estar diante dele. No momento não soube o porquê, mas sei hoje que era pela inversão do ponto de vista. O ponto de vista das fotografias é o mesmo do monumento e não do pedestre. Até agora, só sabia como era vê-lo de perto e avistá-lo de um ônibus em movimento. As fotos me mostraram o que o cavaleiro vê e o cavaleiro é o ponto de vista do monumento. A estrutura e as figuras alegóricas estão em função do cavaleiro e nele culmina o conjunto. Rodeado de céu, vê a cidade de cima.

Do grupo de fotos, uma pareceu-me se referir à situação do monumento naquele lugar (Fig. 18). Mostra a base e as colunas de cima. Vêem-se as cabeças dos construtores, das alegorias e de Ramos de Azevedo, rodeados de arbustos como se se tratasse de uma expedição no meio da selva. O grupo parece perdido. Os construtores empurrando
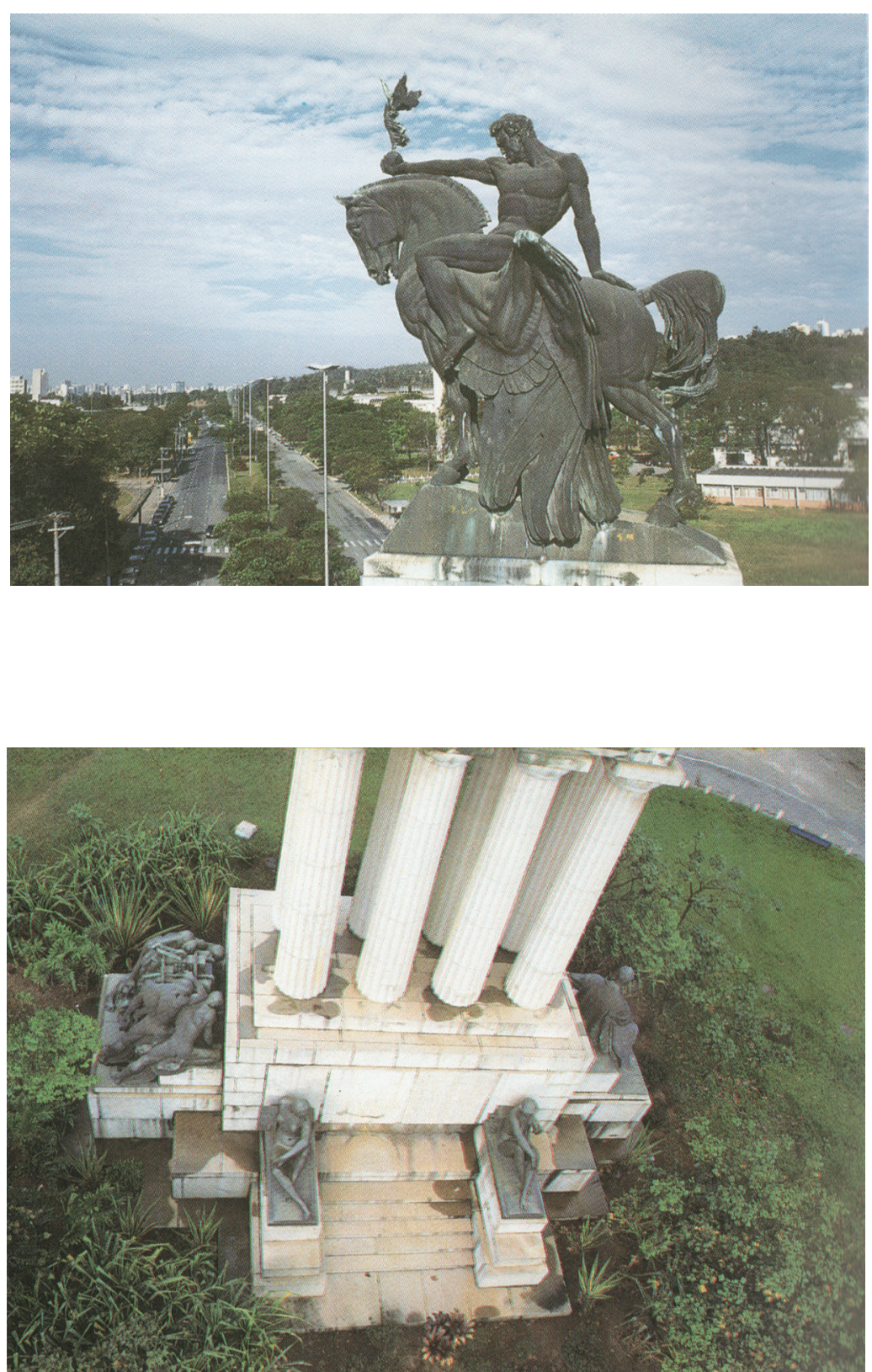

Fig. 18 Registro do monumento a Ramos de Azevedo. Foto: Ângela Célia Garcia, sem data, em Obras Escultóricas em Espaços Externos da USP 
com desespero e Ramos de Azevedo ao mando, buscando a saída. A foto não tem ponto de fuga, está ancorada ao piso. Mostra o monumento torto e tira-lhe a estabilidade visual.

Buscando referências sobre a história do monumento, constatei que a obra de seu autor, Galileo Emendabili, foi influenciada pela tradição escultórica do século passado, conhecida como 'retorno à ordem', trabalhando em torno e adaptando os conceitos mais tradicionais de escultura baseados em cânones clássicos de representação e de ordem compositiva.(2) Suas principais influências foram a teoria e a prática escultórica do artista alemão Adolf von Hildebrand(3) e a poética do escultor eslavo Ivan Mestrovic, ambos muito influentes na vertente escultórica mais tradicional de começos do século XX preocupada com uma dicção realista. A influência de Hildebrand sobre a obra de Emendabili ajudou-me a entender a desproporção do monumento em relação ao lugar que ocupa na Cidade Universitária.

\section{3}

O conceito de 'unidade' na obra de arte, teorizado e praticado por Hildebrand pressupõe dois tipos de recepção visual. Por um lado, uma visão próxima, mais ou menos irrelevante. Por outro, uma visão a distância, que permita à obra aparecer em sua totalidade.(4) Para Hildebrand, a obra cria sentido quando é percebida a distância, pressupõe um ponto de vista privilegiado que possibilite uma visão total e unitária. Este ponto de vista, além de requerer distância, favorece a frontalidade. Qualquer ângulo de visão deveria remeter à sua situação frontal, de maneira que, ao se olhar a obra de frente, se saberia o que há em todos os seus lados.

Em seu lugar original, o monumento a Ramos de Azevedo olhava para a Rua São Caetano. Foi construído em frente à entrada do Liceu de Artes e Ofícios (hoje em dia a Pinacoteca do Estado de São Paulo) para enfatizar simbolicamente a relação entre o prédio e o homenageado. Além de ter construído o prédio, Ramos de Azevedo foi vice-presidente e participou de uma reforma curricular que favoreceu uma educação mais técnica do que teórica no Liceu.

Da Rua São Caetano, o que o observador via, guardando a distância correta com relação ao monumento, era sua parte frontal em perspectiva. E como pano de fundo da mesma composição, o Liceu de Artes e Ofícios.

Em um desenho preliminar do monumento pode-se apreciar sua composição visual plana e em perspectiva(Fig. 19). O conjunto foi criado como uma imagem bidimensional unitária, arranjado de tal forma que gerasse a sensação de profundidade, própria da perspectiva. De uma determinada distância e em linha reta, a percepção visual do monumento deveria ser bidimensional, como em seu desenho. Na metade da imagem, as formas que se apresentam no primeiro plano são a escultura que representa Ramos de Azevedo de corpo inteiro, depois as colunas, seguidas da cabeça do cavalo. Todas no centro da composiçãa. Nos extremos direito e esquerdo, duas alegorias e as escadas, e no último plano, também na parte do fundo, as asas do cavalo. Segundo os conceitos de Hildebrand esta ordem possibilitaria uma composição correta, geradora de profundidade de acordo com a relação humana com a natureza: 
Caso colocássemos no meio de uma imagem, por exemplo, algo que simbolize o próximo e, nas margens, à direita e à esquerda, supomos o distante, a conseqüência imediata será que o movimento de profundidade, partindo do centro como algo próximo, se prolongará até o fundo em direção aos dois lados.(5)

A disposição contrária, com o centro da imagem representado à distância, e as formas da direita e esquerda representadas em primeiro plano, provocaria um movimento de profundidade que faria estreitar o conjunto na medida em que se dirigisse para o fundo. Para Hildebrand, "uma disposição tal impede desde o princípio nossa normal e autêntica relação com a natureza, constringe nossa sensação de espaço em vez de nos induzir ao ilimitado".(6)

Do ponto de vista correto, o espectador estaria em condiçôes de receber a mensagem que a imagem oferecia, simbólica e claramente. Nesta totalidade e unidade da imagem preparada especificamente para a recepção de um conteúdo simbólico, recaía a possibilidade pedagógica do monumento. Sua mensagem ideológica seria transmitida através dessa lógica comunicativa. Para Hildebrand (e para Emendabili), a imagem óptica devia ser composta de tal forma que produzisse uma aparência clara para a leitura do espectador:

Nos capítulos anteriores explicamos a aparência como expressão de nossa representação espacial da natureza. Partíamos da capacidade humana para comprovar a condição espacial da natureza na imagem óptica. Já o notamos facilmente com o olhar, da mesma maneira que falamos que a criança só sabe ler quando ao olhar as letras pode se representar as palavras vivas. A
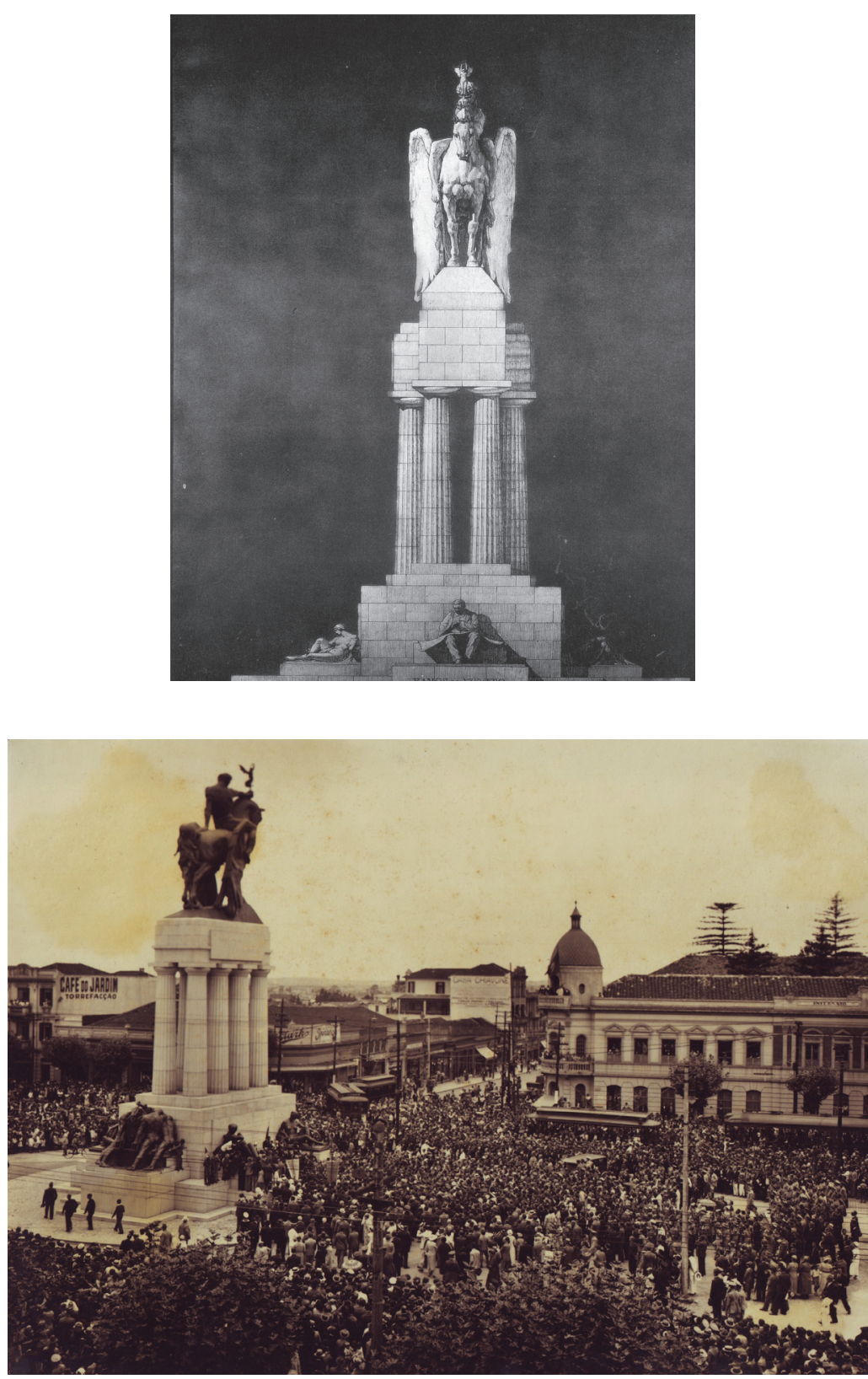

Fig. 20 Inauguração do monumento a Ramos de Azevedo. Foto: Hugo Zanella Arquivo: Bronzes Artísticos Rebellato, 25 jan. 1934.
Fig. 19 Desenho do primeiro projeto para o monumento a Ramos de Azevedo, Galileo Emendabili, 1929. Arquivo Fiammetta Emendabili 
representação artística se configura então como uma aparência que tem sido reconhecida como a mais legível e a que melhor dá ordem ao conteúdo espacial com este fim.(7)

A mensagem ideológica codificada na estética do monumento e sua disposição espacial original assinalavam o seguinte: em frente do Liceu de Artes e Ofícios, o monumento se dirigia às margens da cidade como que puxando-a ao futuro, com seu cavalo do 'Progresso', exibindo os triunfos recentes de um tipo de iniciativa social (a 'Vitória') e demonstrando o trabalho em conjunto de toda a cidade (os 'Construtores'). Tudo isso realizado graças ao planejamento do arquiteto Ramos de Azevedo, um representante idôneo da burguesia emergente, que se consolidava naquele momento.

O monumento foi concebido como unidade idealizada, contida em si mesma e regida pelas leis da perspectiva, mas esta (a perspectiva), além de afirmar sua condição de construção auto-contida, ao mesmo tempo integrava o cenário em volta como parte da mesma composição bidimensional, em um impulso de duas vias. $\mathrm{Na}$ realidade, mais do que manter um diálogo com o contexto, o monumento se impunha perante ele, como personagem principal que atua sobre um cenário e o submete a sua ordem. O conceito de 'unidade' permitia projetar mediante as leis da perspectiva, uma visão idealizada da cidade, entendida na sua totalidade e como imagem.

No seu lugar original, o pedestal do monumento cumpria um papel indicativo, estruturando a lógica específica e simbólica do conjunto, relacionando sua representação ao lugar. Rosalind Krauss, ao refletir sobre o papel do pedestal nos monumentos comemorativos o explica da seguinte maneira:

Se situa em determinado local e fala de forma simbólica sobre o significado ou uso deste local [...] Já que funcionam em relação com a lógica de representação e indicação, as esculturas acostumam a ser figurativas e verticais e seus pedestais são parte importante da estrutura, uma vez que servem de intermediários entre o local e o signo representacional.(8)

A mensagem ideológica efetiva do monumento dependia do lugar onde estava localizado. $\mathrm{O}$ monumento falava deste lugar e a partir deste lugar. Nesta narrativa, o Liceu de Artes e Ofícios representava o progresso recente de São Paulo, porque dali surgiu a mão de obra capaz de construir a cidade imaginada pela burguesia emergente, articulando harmonicamente o conhecimento científico, a arquitetura, as artes e o trabalho. Esta representação se apresentava como ponto de fuga invertido para o resto da cidade, à qual conduzia para o futuro, conectando o sujeito observador com este futuro, colocando-o momentaneamente em uma posição privilegiada de onde era possível olhar para trás (perspectiva do progresso). Ali, o monumento também dialogava diretamente com o 'Parque da Luz' e com a 'Estação da Luz', ambos lugares emblemáticos e marcos históricos da cidade. A história que o monumento narrava era sobre a modernização dinâmica e acelerada de uma cidade que transformava sua fisionomia acolhendo o progresso. Esta área da cidade exercia a função de conexão simbólica e de marco identitário. 
No dia 25 de novembro de 1967 começaram os trabalhos de desmontagem do monumento a Ramos de Azevedo, após discussōes públicas iniciadas na década de 1950, nas quais, segundo Annateresa Fabris, o monumento foi encarado como estorvo.(9) A administração de Faria Lima tomou a decisão. As duas justificativas principais foram a descongestão do trânsito veicular entre o Centro e a Zona Norte da cidade, que era interrompido pelo monumento assentado na Avenida Tiradentes; e a construção da linha de metro Santana-Jabaquara, que passaria pelo mesmo local.

O monumento permaneceu desmontado por alguns anos no 'Jardim da Luz' até 1972, quando teve início sua re-montagem. O lugar escolhido foi uma praça na Cidade Universitária, entre a Escola Politécnica, o Instituto de Pesquisas Tecnológicas e o Instituto de Eletrotécnica, com o propósito de fazer uma nova ligação simbólica entre Ramos de Azevedo e um dos seus legados (a Escola Politécnica, instituição aonde trabalhou como diretor, vice-diretor e professor). $\mathrm{O}$ monumento foi reinaugurado no dia 17 de dezembro de 1975 e até hoje permanece no mesmo lugar.

Quando o monumento foi deslocado e o pedestal 'absorvido'(10), suas lógicas indicativa e narrativa se afetaram. A relação simbólica entre monumento e contexto se interrompeu. Desde suas origens, a Cidade Universitária foi projetada como outra cidade dentro da cidade, como entidade autônoma, à margem. Deslocado, o monumento entrou em outra realidade com parâmetros próprios. Sua visibilidade decresceu, sua presença pública e poder simbólico também. Entrou no terreno suspendido do campus, que maneja uma temporalidade alheia à obra. Sua presença neste espaço é inorgânica.

Com a desmontagem, o papel ordenador e explicativo do pedestal se desestabilizou. A imagem pedagógica e idealizada de cidadania projetada pelo monumento mediante as leis estruturantes da perspectiva, perdeu o equilíbrio. A totalidade dessa aparência se perdeu no tempo e virou fragmento ruinoso. Ainda podemos pensá-lo como monumento comemorativo? Comemorativo de quê? Talvez dos movimentos da cidade ou da desarticulação de uma maneira de se conceber a cidade.

No seu contexto atual, o monumento não narra um passado. É um bom exemplo do que Marc Augé denominou não-lugar, o contrário do que a antropologia tradicional entendia como lugar: dotado de identidade, relacional e histórico.(11) Um não-lugar não proporciona um marco identitário, nem relacional, nem histórico.

Deslocado, o monumento deixa de pertencer a uma estrutura semiótica coerente e articulada. Na Cidade Universitária vira personagem de outra história. Pergunto-me aqui se esta narrativa fragmentada de sobreposiçōes ainda comunica algo.

\section{5}

Continuando minhas excursōes pela Cidade Universitária, desta vez à procura de sentido para o monumento, achei outras duas representações de Ramos de Azevedo. No prédio da Escola Politécnica, em um pátio interno de luz amarelada, há um busto que o representa 


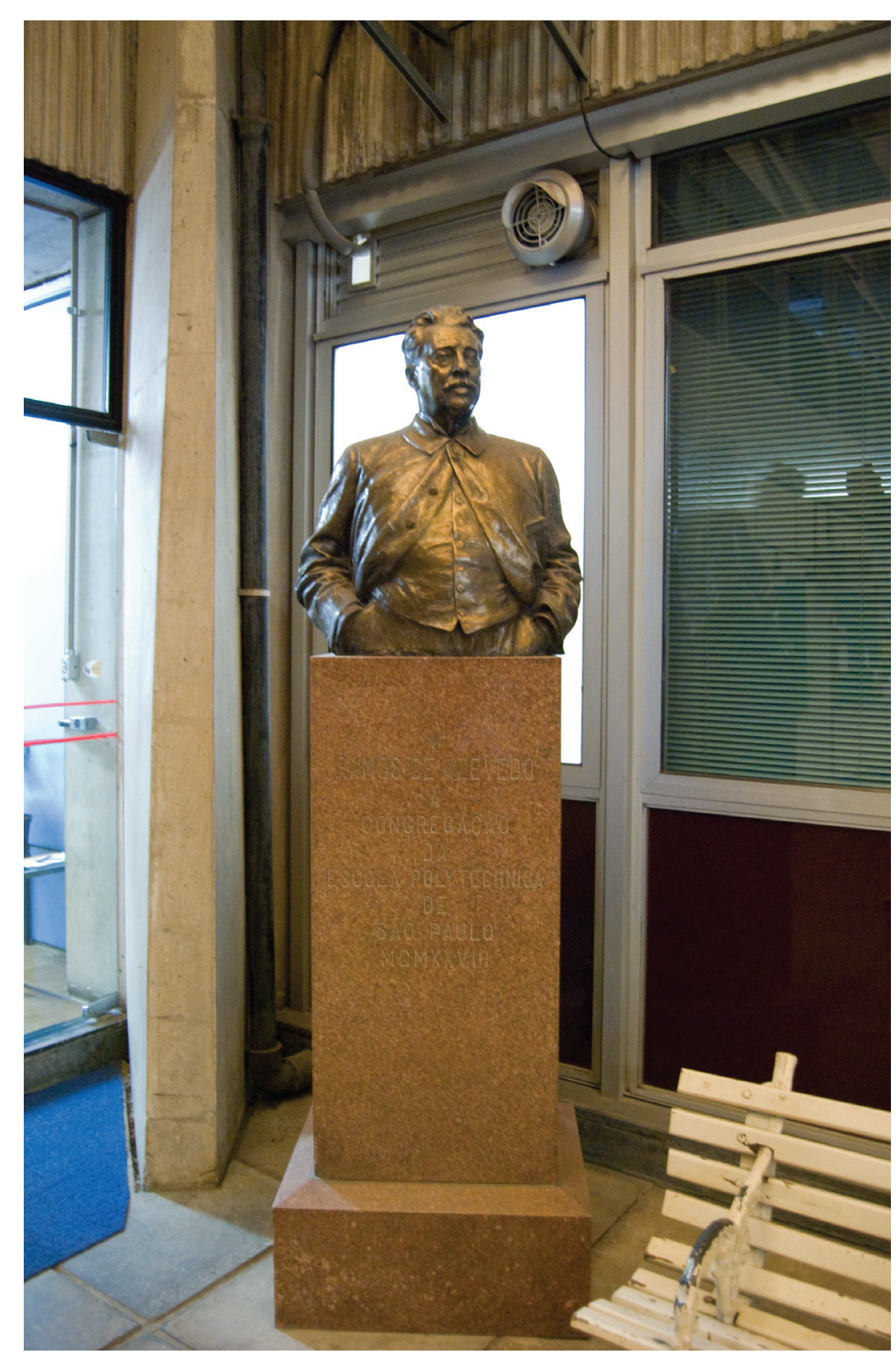

(Fig. 21). No mesmo espaço há outros, muito parecidos entre si, dos quais um se destaca. Fica no meio do patio sobre uma espécie de palco ao qual se chega subindo uma escada suspensa. Não quis subir, preferi me sentar do lado do busto do Ramos e olhá-lo de perto.

No arquivo da Faculdade de Arquitetura e Urbanismo (FAU) há uma foto de Ramos decorando a parede da entrada do espaço (Fig. 22). Não fica muito visível porque a puseram em um canto e sua cor é tênue, parecida com a cor da parede. Na foto está Ramos em pose de trabalho, escrevendo enquanto é retratado. Sobre sua escrivaninha, os objetos que se sobressaem são um grupo de plantas arquitetônicas, muito parecidas com aquelas espalhadas pelo chão do espaço do arquivo. A estética do lugar se reflete na representação e vice-versa.

Busto e foto assinalam a presença do Ramos de Azevedo nas duas faculdades. Seu legado é comemorado simbolicamente de maneira modesta, ficando estas representações quase perdidas nos seus locais de exposição. Dificilmente conseguem reativar memória. Nesse sentido sua situação se assemelha à do monumento a Ramos de Azevedo. Pensei que talvez houvessem outras representações de Ramos na Cidade Universitária e que a dificuldade para gerar memória fosse o fio condutor do grupo. Procurei outras obras que dialogassem com o monumento desta ou de outra forma e que fizessem sentido coletivamente.

Por algum tempo me pareceu que a maneira mais apropriada de interpretar o monumento no contexto da Cidade Universitária era entendendo-o como parte do cosmos de obras dentro do campus. Como fragmento orgânico de um 'discurso coerente', algo assim como uma 
obra dentro de uma coleção. $\mathrm{Na}$ Universidade há diferentes coleções e não só de obras de arte. Há Museu de Arte Contemporânea (MAC), Museu de Zoologia, Museu de Arqueologia e Etnologia, está o Paço das Artes, há coleçôes de reproduções, de objetos significativos para a geologia, de objetos pedagógicos e outros objetos de memória. Dentro destes agrupamentos pode-se entrever diversos discursos que usam tons variados e perseguem fins diferentes. Qual seria a articulação que faria integrar-se o monumento a Ramos de Azevedo?

$\mathrm{Na}$ biblioteca da Escola de Comunicações e Artes (ECA) encontrei dois livros nos quais as esculturas da Universidade estão catalogadas.(12) Oferecem fotos de registro, informação sobre autoria, título, data, tema e outros dados explicativos. Sua representação das obras as reúne como grupo, sob uma influência museológica, como se na prática realmente fossem uma agrupação propositiva. Em um dos dois aparece o monumento a Ramos de Azevedo conformando o grupo de esculturas em espaços externos.

Uma coleção exerce um núcleo de atração que trabalha como campo de força de equivalências. Cada peça individual entra no mundo de relações gerado pela acumulação do colecionador, gravita nesse 'círculo mágico', como foi chamado por Walter Benjamin, que permite combinar diferentes objetos.

Sob a ótica dos catálogos mencionados, as praças, jardins e parques da Cidade Universitária proveriam um espaço discursivo comum para as obras. Um microcosmo que propõe uma seleção, critérios de acumulação, modalidades de combinação e formas de exibição. O grupo de obras geraria uma narrativa, um discurso e uma memória.

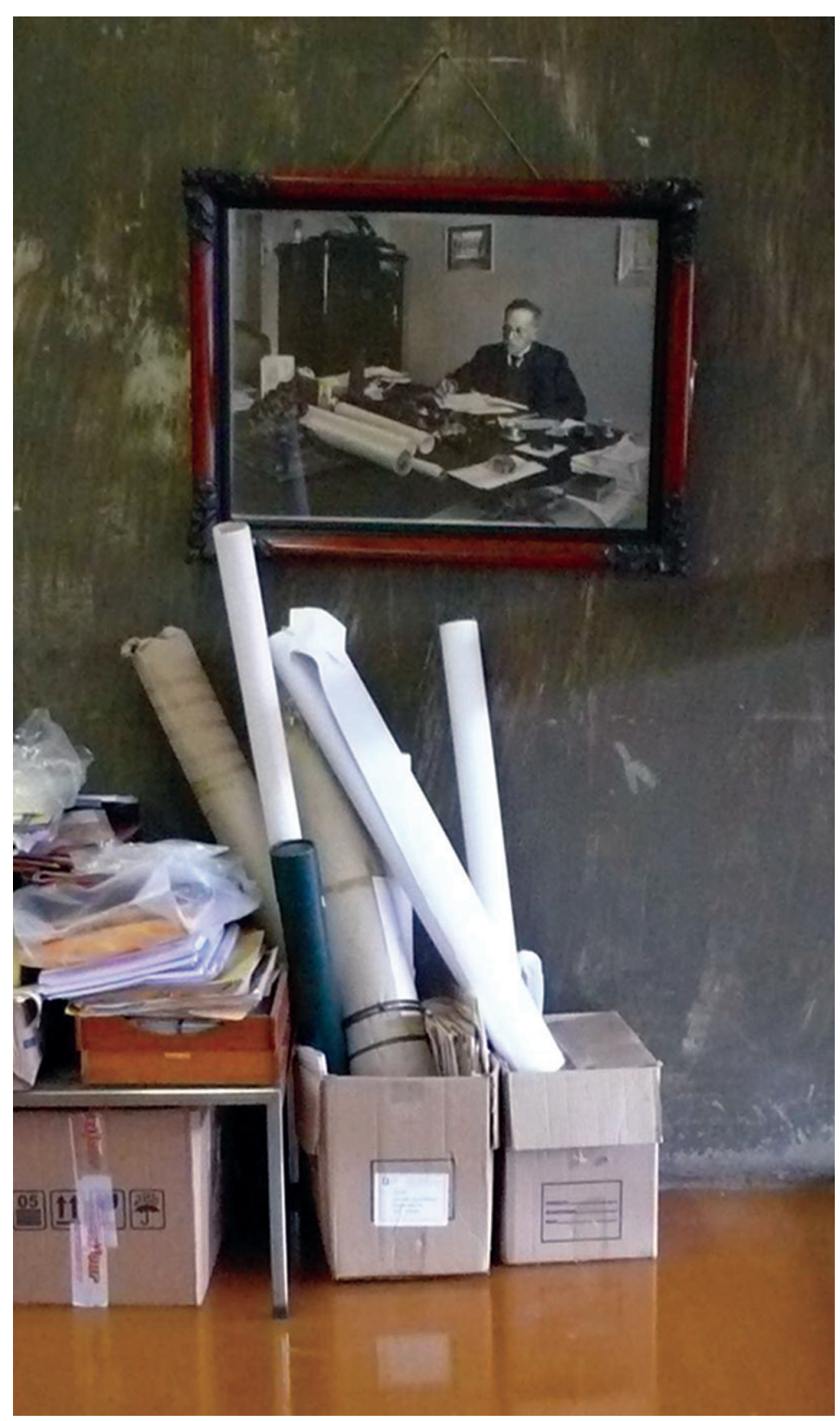

Fig 22. Retrato fotográfico de Ramos de Azevedo no arquivo da FAU. Autor e data desconhecidos. 
46

Fig. 23 Título, autor e data desconhecidos

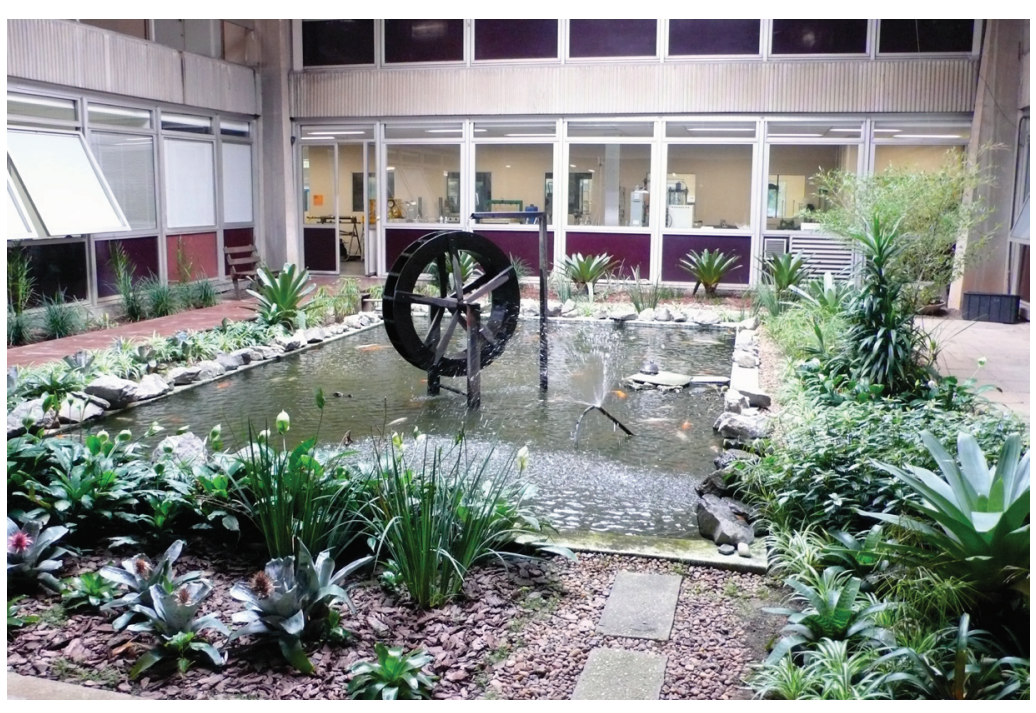

Fig. 24 Sem Titulo, José Resende, 1994
A clareza expressada pelos dois catálogos de esculturas na USP é oposta à percepção cotidiana que tenho delas. Nesses casos, a pulsão por inventariar os bens culturais da Universidade -adjetivo que é imediatamente atraído pelas palavras 'escultura' e 'obra'- cria uma paisagem comemorativa forçada, "comunicando valores e referenciando caminhos"(13), que se encontram mais na base de dados do que na paisagem vivida.

\section{6}

Enquanto responde as perguntas da prova, um estudante olha pela janela e vê algo que pode ser confundido com um moinho de vento (Fig. 23). Tem peixes vivos dentro, que pensa serem carpas. Seria uma demonstração de energia cinética? A comemoração de algum descobrimento? As cenas dessa janela devem acompanhá-lo desde quando começou a freqüentar a faculdade, mas nunca havia reparado naquela roda. O estudante não percebe que o observo. Olha de novo para a roda como que procurando as respostas no seu movimento, como se o decifrar de seu mecanismo dependesse o questionário à sua frente.

Em um local próximo do que está a roda, na mesma Escola Politécnica, há outro objeto comemorativo que remete ao conhecimento científico (fFig. 24). Este tem uma escala monumental, porém sua presença é discreta e consegue se mimetizar com o ambiente.

São duas grandes chapas de aço em estado potencial. Estão dobradas, de maneira que se curvam formando dois esses forçados. Como o movimento inicial de uma Cobra ao enfrentar seu inimigo 
ou antes de morder sua presa. O material das chapas se aprecia em estado cru, curtido pela exposição à intempérie. Não representa nada de não ser sua materialidade e sua energia potencial. Sinto seu peso e a tensão da suspensão.

Pergunto-me como serão vistas pelos alunos da faculdade que as tem como parte do seu cotidiano. Um estudante olha para elas com o canto dos olhos enquanto decifra fórmulas escritas na lousa. Energia cinética por um lado e energia potencial pelo outro.

E se se tratasse de um escorregador? A experiência empírica de se deslizar seria considerada como dado comparativo de experimentação. Isso explica que haja duas chapas e não uma. Permite comparar o tempo que leva o percurso de pessoas de pesos diferentes se deslizando ao mesmo tempo. E se os cabos se soltassem, as chapas ainda se manteriam em pé? Eu acho que sim, que o artista só os pôs ali para criar essa tensão por dependência.

Entre os autores das esculturas que encontrei nos espaços exteriores do campus conhecia obras de Amilcar de Castro, de José Resende, de Ester Grinspum e claro, de Galileo Emendabili. Da maioria nunca tinha ouvido falar. Deparei-me com toda classe de bustos comemorativos, muitas abstraçôes geométricas, um relógio solar, um sino, a torre do relógio, dois troncos verticais, que se não fosse pela placa com dados que os acompanha, talvez nunca houvesse adivinhado que eram uma obra.

Como chegaram estas obras até aqui? Por que há duas de Caetano Fracaroli? Fica difícil achar uma vontade propositiva que permita narrar o espaço entre estas. Os troncos, Amilcar de Castro, o monumento...
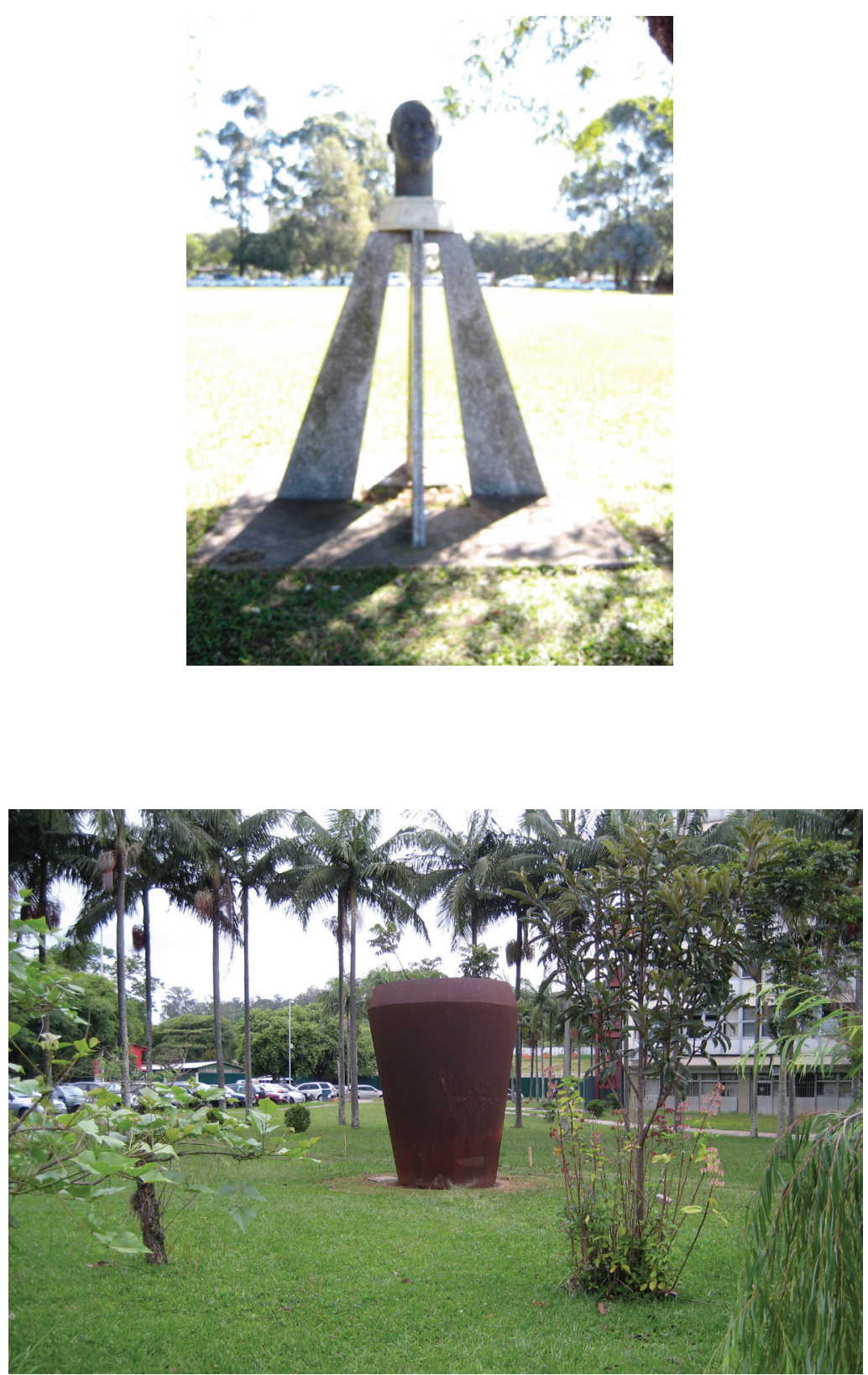

Fig. 25 Homenagem a Júlio de Mesquita Filho, Caetano Fracaroli,1969.

Fig. 26 Sem Titulo, Ester Grinspum, 1988. 

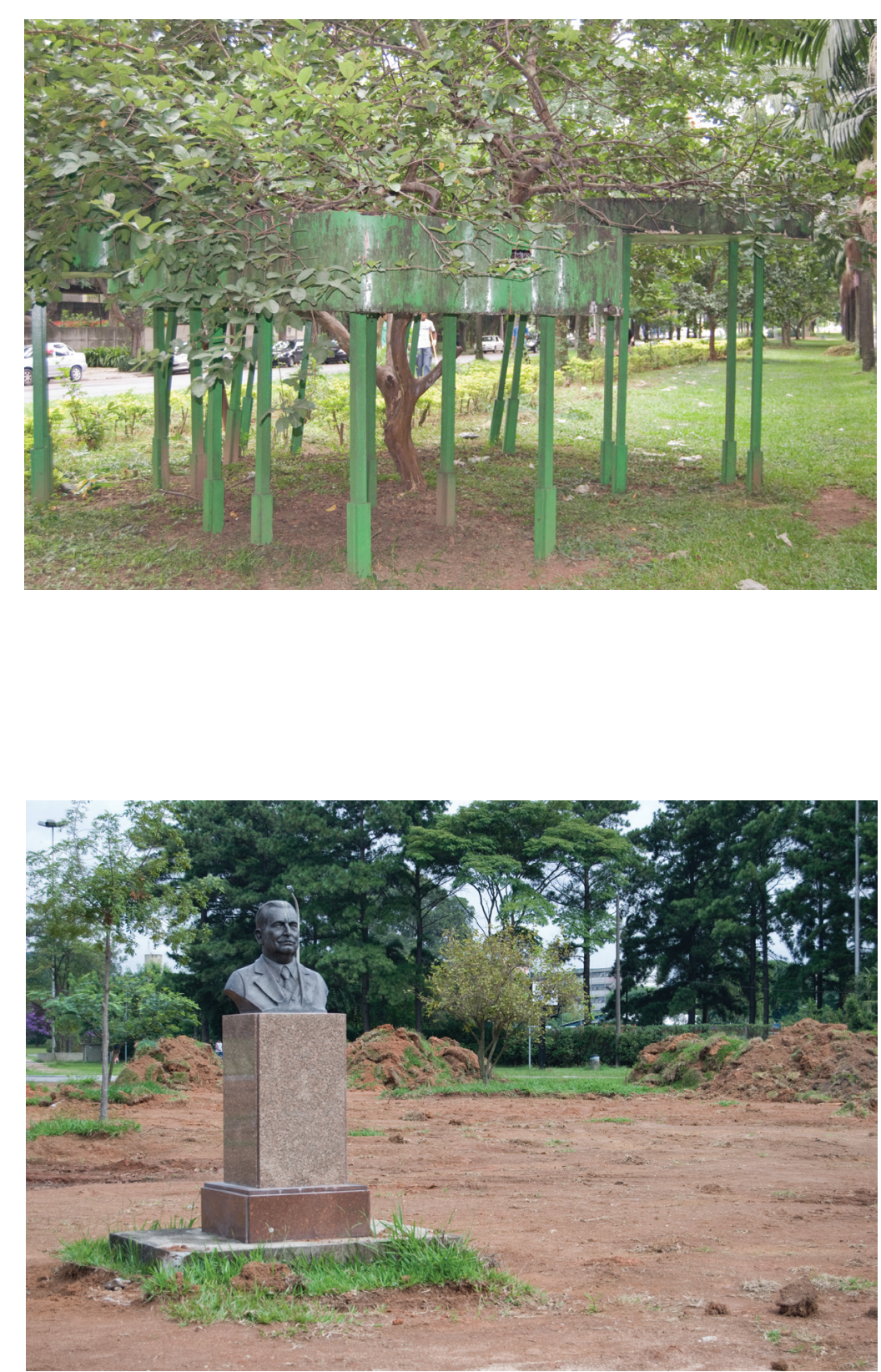
8

A escultura segue a árvore e a árvore contorna a escultura (Fig. 27). Suas formas se abrem como um leque chinês que aos poucos deixa ver os traços da paisagem pintada na sua superfície. Em alguns trechos lhe serve de descanso aos galhos maiores da árvore, confundindo ainda mais o final de um e o início do outro.

Uma simbiose bem lograda pelo tempo faz com que a terra absorva a madeira da escultura, já enredada com os galhos mortos da árvore. Os fragmentos da escultura querem ser galhos, crescer como estes, descansar sobre esculturas, cair no chão, ser absorvidos e começar outra etapa do ciclo.

Já aconteceu que os jardineiros, pretendendo podar a árvore, cortaram pedaços da escultura. Não são os únicos. Uma família de pássaros construiu o ninho deles em um dos cantos superiores da escultura e passam boa parte do dia cantando sobre os galhos da árvore. Seguramente entenderam essa união como a continuidade de um único organismo e não como duas coisas separadas, como fizeram os jardineiros.

Meu percurso acaba no busto de Ernesto de Souza Campos (Fig. 28). Vejo-o boiar dentro da sua pracinha como se se tratasse de uma ilha sendo engolida pelo mar. A única coisa que o mantém na superfície é aquele pedestal rosa pálido, que a qualquer momento pode ceder e se incorporar. 
Este busto conta uma história, a confluência da vida de Ernesto de Souza Campos e a Cidade Universitária. Ele foi um dos articuladores da criação da Universidade de São Paulo e por isso foi reconhecido e imortalizado no bronze. Em 1982, o reitor da Universidade na época -Antonio Hélio Guerra Vieira- presidiu a cerimônia pública que inaugurou a estátua, comemorando o centenário do nascimento do homenageado.(14)

Esta imagem solitária, a relação entre as obras do campus -ou sua falta- e as grandes distâncias dos caminhos entre elas, dizem respeito ao espaço compartimentado da Cidade Universitária. De certa forma se espelha a dificuldade de comunicação entre as faculdades, tão distantes as umas das outras.

Vi uma criança correndo entre as colunas do monumento a Ramos. Não sei como subiu, pois entre esse ponto e as escadas há um espaço considerável, mais do triplo da sua altura. Devia ter por volta de 10 anos. Quem sabe se é algo que ela faz com frequiência, talvez more perto.

Parecia um felino solitário. Seus passos eram mudos e se deslocavam sem deixar rastros. Não pude acompanhar o movimento consecutivamente. Aparecia de vez em quando, de um lugar para outro, em saltos perceptivos. Se assomava por detrás das colunas e desaparecia

\footnotetext{
segundos depois. Olhou para mim enquanto tirava uma foto dele.
}

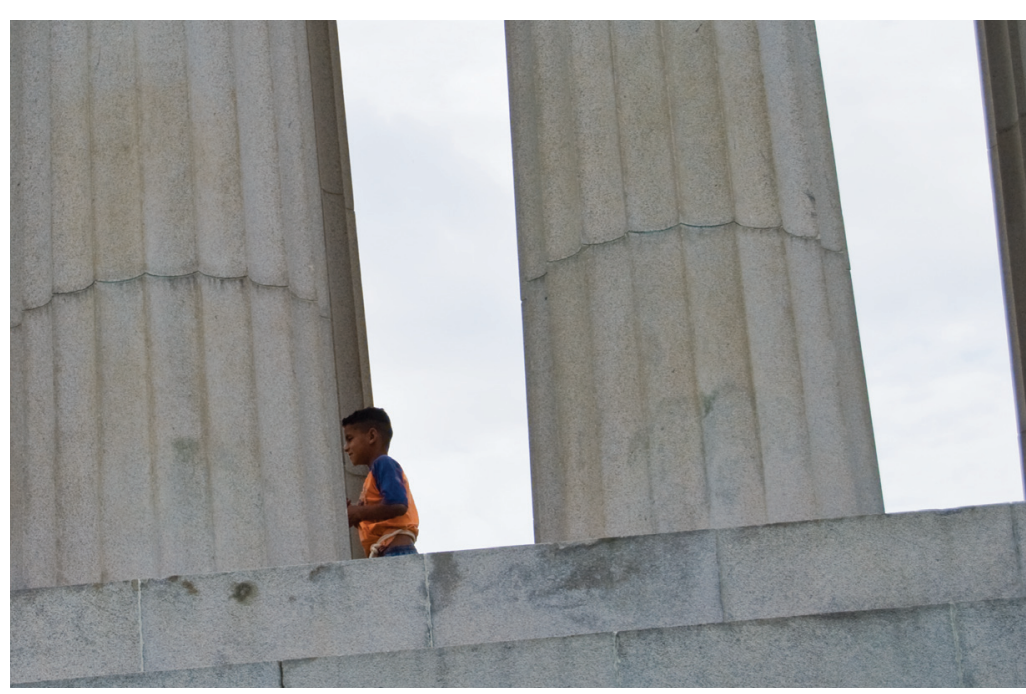

Fig. 29 Registro do monumento a Ramos de Azevedo. Foto: Delenguaamano, 2008 


\section{Notas}

1. FRANÇA LOURENÇO, Maria Cecília (org.), 'Obras Escultóricas em Espaços Externos da USP’, Editora da Universidade de São Paulo, São Paulo, 1997, pg. 92-99.

2. CHIARELl, Tadeu, 'A Obra de Galileo Emendabili: Síntese e Superação de Influências', in: 'Monumento a Ramos de Azevedo: Do Concurso ao Exílio', Mercado de Letras, Campinas, 1997, pg. 66.

3. Dois pontos de vista diferentes sobre a obra deste artista podem se encontrar em: KRAUSS, Rosalind, 'Caminhos da Escultura Moderna’, tradução de Julio Fischer, Martins Fontes, São Paulo, 2001 e WITTKOWER, Rudolf, 'Escultura', Martins Fontes, São Paulo, 1989.

4. CHIARELLI, Op. Cit., pg. 47.

5. HILDEBRAND VON, Adolf, 'El Problema de la Forma en la Obra de Arte', tradução ao espanhol de Maria Isabel Peña Aguado, Visor, Madrid, 1988, pg. 58. (Tradução minha).

6. HILDEBRAND VON, Op, Cit., pg. 59. (Tradução minha).

7. HILDEBRAND VON, $O p$, Cit., pg. 79. (Tradução minha).

8. KRAUSS, Rosalind, 'Sculpture in the Expanded Field', in: 'The Originality of the Avant-Garde and Other Modernist Myths', The MIT Press, Cambridge, Massachusetts, London, 1985, pg. 279. (Tradução minha).

9. FABRIS, Annateresa, 'Monumento a Ramos de Azevedo: Do Concurso ao Exílio', Mercado de Letras, Campinas, 1997, pg. 46.
10. Termo usado por Rosalind Krauss para descrever uma mudança qualitativa na história da escultura, característico da escultura moderna: KRAUSS, 'Sculpture in the Expanded Field', Op. Cit., pg. 280.

11. AUGÉ, Marc, 'Los No Lugares, Espacios del Anonimato: Una Antropología de la Sobremodernidad', tradução ao espanhol de Margarita N. Mizraji, Editora Gedisa, Barcelona, 1993, pg. 83.

12. FRANÇA LOURENÇO, Maria Cecília (org.), 'Homenagem aos Mestres: Esculturas na USP’, Editora da Universidade de São Paulo, São Paulo, 2002. O outro livro está citado na primeira nota deste capítulo.

13. FRANÇA LOURENÇO, 'Obras Escultóricas em Espaços Externos da USP', Op. Cit., pg. 14.

14. FRANÇA LOURENÇO, Op. Cit., pg. 40. 
álbum fotográfico de Bronzes Artísticos Rebellato:

trabalho, alegoria e ruína 
1

O 'Museu Imaginário' de André Malraux (1901-1976) pretendeu aumentar em proporções inéditas a área de influência do museu. Suas possibilidades, para além do museu físico, baseavam-se no aprofundamento da 'metamorfose' da obra de arte que, na leitura de Malraux, teve na fotografia uma aliada funcional. Segundo ele, seu papel consistiu em permitir uma maior circulação e disponibilidade da arte, como também em aprofundar sua descontextualização, ao separar as obras da função original para a qual foram criadas, e revelar características pouco visíveis, se valendo das possibilidades perceptivas do olho mecânico da câmera e dos processos fotográficos; fragmentação, ampliação, iluminação acertada, enfoques em áreas específicas de interesse, etc.

Como seu nome sugere, a possibilidade de constituição do 'Museu Imaginário' é independente da fisicalidade de um lugar. Funcionaria como espaço virtual construído por imagens. Nele, a fotografia continuaria o legado do museu, revelando a arte como arte, desvendando as instrumentalizaçóes culturais às quais tinha sido submetida historicamente e as quais impossibilitavam apreciar sua essência (antes do museu, da arte moderna e da fotografia). As obras abandonariam de maneira definitiva suas funçôes sociais, rituais e/ou religiosas de origem e seu estatuto de posse, ou seja, passariam de um âmbito específico, sagrado e privado a outro universal, laico e público.

Também perderiam sua condição objetual, enquanto ganhariam clareza em estilo e pertencimento à grande família da Arte:
Em nosso Museu Imaginário, quadros, afrescos, miniaturas, e vitrais parecem da mesma família. Porque todos -miniaturas, frescos, vitrais, tapeçaria, placas Sythianas, quadros, pinturas gregas em vasos, 'detalhes' e até estátuas- tornaram-se reproduçôes coloridas. No processo perderam suas propriedades como objetos; mas, pela mesma moeda, adquiriram algo: o máximo significado como estilo que possivelmente possam adquirir.(1)

Para Malraux, a fotografia servia ao 'Museu Imaginário' como veículo do princípio homogeneizante de estilo, fio condutor de sua narrativa totalizante. Desde esse ponto de vista, a fotografia seria o meio que permite estabelecer o principio de equivalência e identificar e categorizar cada manifestação artística de acordo com seu respectivo estilo. Isso, mediante uma operação que desmaterializa o objeto e oferece a plataforma comum que permite estabelecer uma relação comparativa entre as imagens resultantes.

Dessa forma, a fotografia participaria do movimento de separação das obras de arte da igreja, do templo, do palácio, e facilitaria a função classificatória do museu.

\section{2}

Enquanto procurávamos uma fundição para realizar uma das obras de Monumetria(2), meus companheiros de grupo e eu chegamos a Bronzes Artísticos Rebellato Ltda. O lugar, que ao primeiro contato visual revelava capas densas e sobrepostas de história, me remeteu imediatamente ao monumento. Foram eles, pelas mãos de três gerações 
anteriores, que fundiram as peças do monumento a Ramos de Azevedo. Patrícia, a neta de Giuseppe Rebellato -responsável pela fundição do monumento- havia assumido a administração do local fazia pouco, depois da morte do pai. Atualmente divide seu tempo entre a fundição e seu negócio, uma gráfica.

Ao mostrarmos interesse pela história da fundição, Patrícia e dois dos empregados que permaneceram, ofereceram-nos um passeio pelo lugar. Mostraram-nos peças velhas que haviam fundido e outras que ficaram em processo. Também explicaram-nos passo a passo o processo de fundição. À medida em que comentavam sobre o oficio, o lugar e sua história, o ambiente tornava-se a cada vez mais nostálgico. Passado um tempo, revelaram algo que já se pressentia, que pensavam em fechar o negócio. As razões para isso falam de uma época, não somente de um caso particular.

Atualmente, as esculturas em bronze dificilmente encontram compradores. A maioria das encomendas da fundição eram destinadas ao cemitério e à praça pública; a oficina, inclusive, fica muito perto do Cemitério São Paulo. Em uma época de gratificações imediatas, não há reconhecimento na comemoração duradoura. O espaço aonde se pratica o culto à morte não é mais o cemitério e lembrar os mortos deixou de ter uma importância social fundamental. Além de uma forma de lembrar, o que está se fechando com Bronzes Artísticos Rebellato é uma maneira de produzir. Segundo Patrícia, nem ela nem seus irmãos aprenderam o oficio do pai.

Ao perguntarmos por fotos e outros documentos relacionados ao monumento, soubemos que a fundição estava se desfazendo do arquivo dos projetos realizados no passado, e até o momento guardados pela família. Mostraram-nos um álbum de fotos com registros da construção do monumento a Ramos de Azevedo, conjunto esse de interesse e foco desta pesquisa. O álbum constitui um documento que guarda a memória fotográfica da construção do monumento. Contém representaçôes do monumento que o desconstroem e o re-espacializam de maneira singular. Há uma ordem e uma articulação entre imagens cuja natureza parece revelar características narrativas, por seus respectivos intervalos, conexões e tensões. As fotografias assim dispostas e apresentadas podem ser pensadas como uma montagem.

O álbum é um testemunho do monumento. Curiosamente, a fotografia passa a substituir o monumento como memória. Vira a memória de uma memória. Digo curiosamente porque, embora ambas formas de representação funcionem como prótese para a memória humana, encarnam valores temporais inversos. Diversas versôes de monumento têm sido usadas ao longo dos séculos por sociedades tradicionais e modernas para prolongar a vida e desafiar a morte. Esta maneira de lembrar pretende a imortalidade. A fotografia não tem nenhuma intenção de duração eterna, está regida pela contingência. Barthes (1915-1980) assinala o paradoxo contido no tipo de memória propiciado pela Fotografia em relação com a História:

[...] o mesmo século inventou a História e a Fotografia. Mas a História é uma memória fabricada segundo receitas positivas, um puro discurso intelectual que abole o Tempo mítico; e a Fotografia é um testemunho seguro, mas fugaz; de modo que, hoje, tudo prepara nossa espécie para essa impotência: não poder mais, em breve, conceber, 

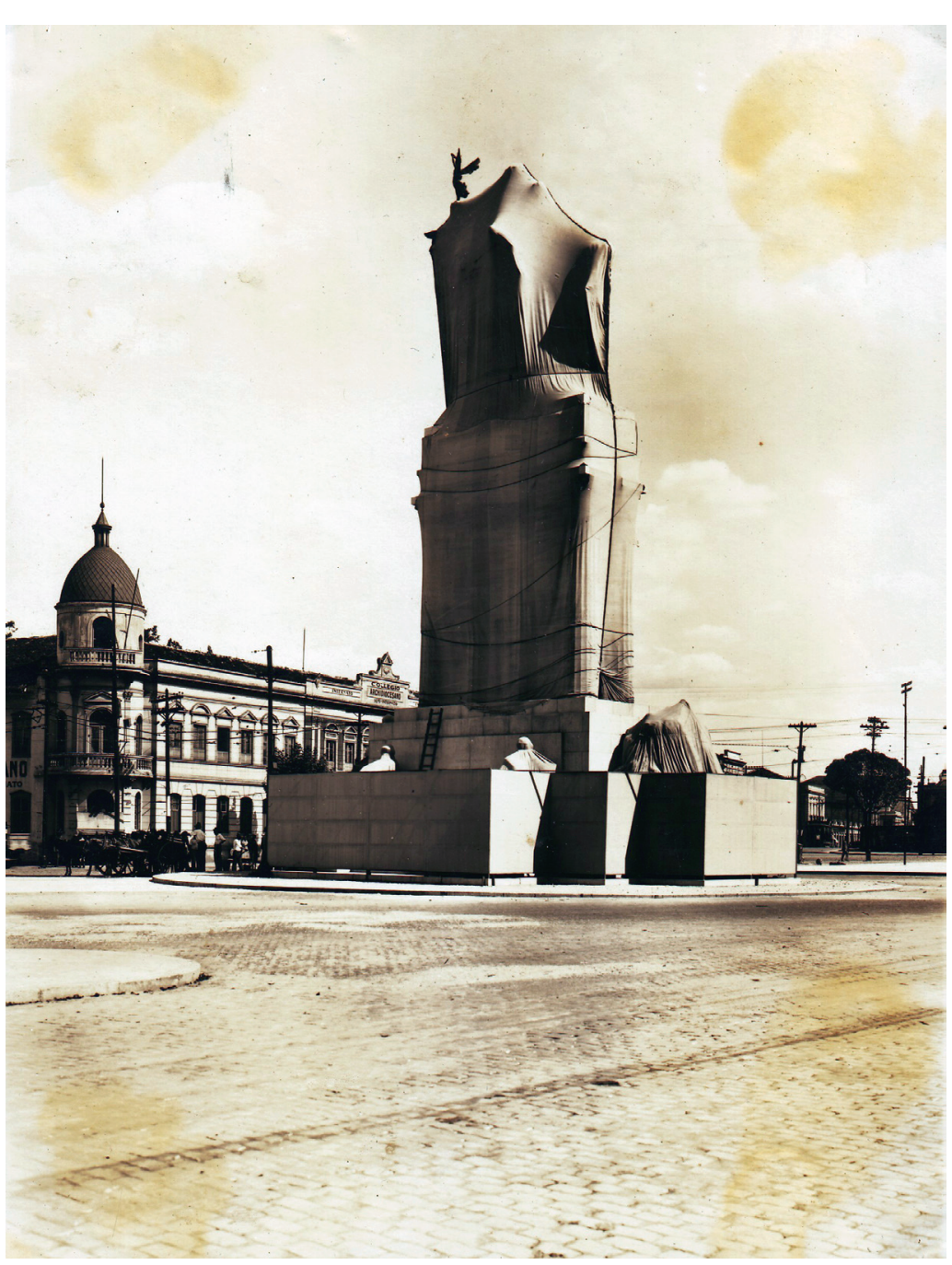

afetivamente ou simbolicamente, a duração: a era da Fotografia é também a das revoluçôes, das contestações, dos atentados, das explosões, em suma, das impaciências, de tudo o que denega o amadurecimento. - E sem dúvida o espanto do "Isso foi” também desaparecerá. Já desapareceu. Sou, não sei por que, uma de suas últimas testemunhas (testemunha do Inatual), e este livro é o seu traço arcaico.(3)

De fato, ao ser representado e rememorado em fotografias, o monumento se transforma. $\mathrm{O}$ que para Malraux aconteceria em direção à equivalência iluminadora e unificada, para Barthes mantém a possibilidade de conexão com um tempo 'mitológico', 'arcáico' e alucinado. Parece que o conjunto de fotos contidas no álbum se debate entre ambos extremos. Por um lado, a intenção positiva e objetiva de documentar, classificando separadamente as etapas de construção e os elementos do monumento, e por outro, a experiência de um espaçotempo emaranhado, que se desenvolve de maneira contraditória. Entre testemunho certeiro e duradouro e narração de uma condição efêmera. Como que preparando o observador a ver o monumento como contingência.

A foto que abre o álbum mostra o monumento a Ramos de Azevedo coberto pelo que parece ser uma lona (Fig. 30). Não vemos as colunas claramente, nem o cavalo, nem o 'Gênio', somente nos é permitido acompanhar sua silhueta contornada e a figura da 'Vitória'. O conjunto está amarrado por laços envolventes, afirmando a ação 
de encobrimento. A imagem remete ao procedimento recorrente de Christo (1935-), artista em atividade desde os anos 70, que interveio em grandes porçôes de paisagem rural e em construções tão simbólicas como, por exemplo, o Reichstag em Berlim.

$\mathrm{Na}$ foto, como nas obras do artista, o gesto de cobrir nega a visibilidade e ao mesmo tempo torna mais visível. Não podemos ver o que está por baixo da lona mas sua ausência é tão gritante que chama a atenção. Gera uma visibilidade potencial mediante a negação. $\mathrm{Na}$ foto, são os matizes escuros se concentram na parte central da imagem, sendo o branco predominante na área superior e inferior. A mancha central está composta pelo monumento coberto pela lona e por uma estrutura de madeira, o colégio Arquidiocesano, algumas árvores, postes de luz, edifícios não identificados e um grupo de pessoas em volta de uma carroça. $\mathrm{O}$ monumento é o centro vertical da imagem. Toda a atenção dirige-se a ele. A concentração visual aprofunda-se porque o que sobra da foto tende ao branco, como se o monumento e a mancha escura que o segue estivessem flutuando em um abismo branco indiferenciado. $\mathrm{O}$ céu e a rua são a moldura que contém o monumento.

Esta foto pode ser interpretada como uma advertência. Talvez sua opacidade esteja nos avisando que nas seguintes páginas não encontraremos o monumento. O que nos é permitido ver, é o esforço em cobri-lo: a lona apertada entre laços, cheia de rugas. Estamos entrando no terreno transformador da alegoria.

A imagem nos confronta com um enigma. Ao ocultar o objeto da nossa vista provoca em nós desejo de percorrê-lo, tentando decifrá-lo. Mas o enigma não consiste em des-cobrir o monumento, em adivinhar o que há por baixo da lona, isso já sabemos. O interesva do álbum. Podemos aqui nos remeter a duas fotografias de Man Ray (1890-1976), L'énigme d'sidore Ducasse, de 1920 e Enigme II, de 1935. Ambas ocultam um conteúdo cuja forma e volume são sugeridos por envoltórios amarrados que negam seu interior. Ficamos com uma imagem da superfície que envolve e sem direito a percorrer visualmente o interior. No entanto, esse interior existe e se mantém perpetuamente pulsante porque jamais se revela, diferentemente da lógica fotográfica que depende do revelado e do que este inscreve na superfície e permite ver. Ou seja, o conteúdo está confeccionado por pura potencialidade, em um jogo aberto e sem possibilidade de resolução baseado na adivinhação.

As duas fotos oscilam tonalmente entre o preto e o branco. Em L'énigme d'sidore Ducasse, a superfície da área oculta é representada em preto, em contraste com o fundo branco. Em Enigme II, o envoltório é branco e o espaço circundante preto. Faço esta diferenciação entre figura e fundo porque ambos pacotes estão situados em vazios opostos, o primeiro é de luz e o segundo de sombra. Como fotos, existem num tempo congelado que circula como imagem e se oferecem na forma do enigma perpétuo. Talvez o que esses envoltórios capturam e guardam com tanto zelo seja o tempo, representado entre as possibilidades de dois extremos cegos, a presença total de vibraçôes lumínicas (branco) e a ausência total de luz (preto). O tempo deve ficar suspendido entre os envoltórios e congelado na fotografia porque, no caso de lhe ser permitido fluir livremente, queima a imagem e nega qualquer representação. 
Fig. 31 Inauguração do monumento a Ramos de Azevedo, 25 jan. 1934. Foto: Hugo Zanella. Arquivo: Bronzes Artísticos Rebellato.

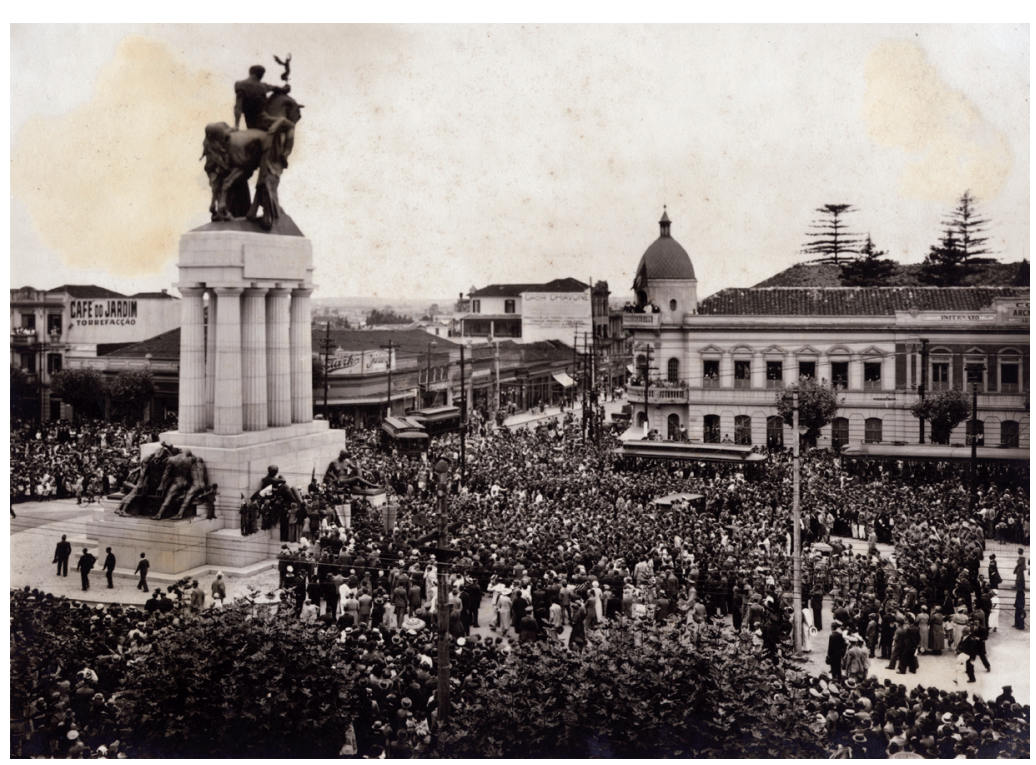

Fig. 32 Monumento a Ramos de Azevedo na Avenida Tiradentes. Foto: Hugo Zanella. Arquivo: Bronzes Artísticos Rebellato.

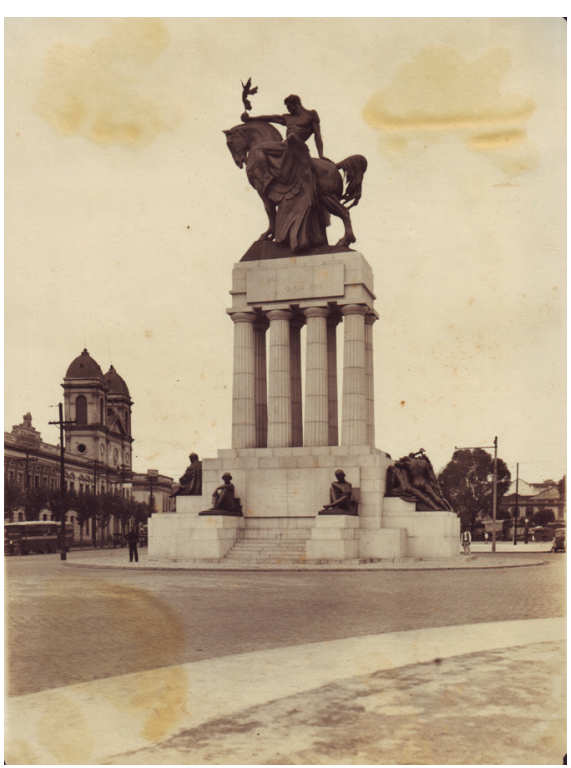

De Chirico (1888-1978) também prestou especial atenção à estrutura visual do enigma. Suas pinturas estão habitadas por um repertório eclético de objetos, que juntos, constroem cenas inverossímeis. Em geral, estes objetos provém de épocas distintas e representam momentos históricos paradigmáticos e reconhecíveis. Arquiteturas romanas, gregas e modernas, estatuaria de cânones clássicos, relógios, trens, e outros objetos mecânicos, interagem com figuras humanas e outros organismos vivos.

Em O Enigma de um Dia'(1914), pintura que faz parte da coleção do MAC-USP, co-habitam um trem em movimento, uma estátua comemorativa de figura humana, dois fragmentos de arquitetura clássica, duas torres modernas e duas pessoas.

O cenário do enigma é construído pelo encontro de objetos deslocados dos seus contextos, que juntos provocam uma temporalidade misturada. Como nas fotos de Man Ray, o tempo está suspendido dentro de um espaço que admite contrastes e desencontros e acaba tornando opaca uma visão direta. No caso do monumento coberto, seu significado simbólico fica suspenso.

Paradoxalmente, a segunda foto do álbum mostra uma cena plena (Fig. 31). Nada se oculta. Todos seus elementos são apresentados da maneira mais detalhada possível, sem que por isso seja sacrificado um ponto de vista abarcador. Inclusive, se adverte a vontade de acomodar uma cena ampla, exaustiva nos fragmentos e nos detalhes. 
Se na foto anterior o monumento estava oculto, nesta é protagonista principal de uma cena sintética e plena de significado e visibilidade.

Vemos e distinguimos claramente o monumento desde a parte posterior, num ângulo que revela o lado onde estão as alegorias à escultura e à engenharia. $\mathrm{O}$ colégio Arquidiocesano também está à vista. Os outros elementos fundamentais da composição são o bonde e a multidão.

Estes últimos e o monumento são os personagens principais da foto. É como se no instante da foto houvesse ocorrido uma simbiose dos três. Os vagões do bonde e um carro atravessam a maré de gente que os inunda e se apropria deles. Entram no estômago da multidão. Todos em volta do monumento, participando de um rito de comemoração que abona o futuro. Comemora-se um homem, mediante o qual se recupera um passado mítico, um retorno às origens com as quais uma parcela da sociedade se identifica. Um rito que pretende afiançar os laços de identificação coletiva por meio de uma imagem.

Esta foto lembra esse rito. O momento no qual o símbolo de modernidade representado pelo bonde é possuído pelos habitantes da cidade, representados em uníssono como multidão -aquela personagem urbana na qual se desmancham as individualidades-. Todos rodeando o totem erguido e se projetando ao futuro.

\section{5}

Na seguinte foto (Fig. 32), o monumento, mais uma vez é representado isoladamente. Se observarmos com atenção, veremos algumas pessoas em volta. Também casas, carros e árvores, mas na foto são pouque a sua dimensão dialoga com a multidão mas não com o individuo que, ao lado dele, é insignificante. Há uma ênfase na unidade do monumento como totalidade e na sua autonomia. Aparece como símbolo claro e fechado. Depois da celebração, o monumento descansa.

6

Depois de ser representado como presença solitária, há uma série de imagens nas quais o monumento é apreciado em partes. Fragmentado, alguns elementos são apresentados individualmente, em cenários inverossímeis, embora mundanos. Este grupo de imagens expõe a capacidade alegórica contida na fotografia e seu efeito sobre o sentido do monumento. Gera o registro de um processo de mudança, ao estabilizá-lo em imagem. Mostra uma fase inédita do monumento, desarticulado em partes, recombinadas entre elas e encenadas em palcos improváveis. Nestas fotos, a totalidade orgânica do monumento se fragmenta e se reorganiza. O monumento morre como símbolo fechado e se exibem seus fragmentos dissecados, como elementos individuais.

A noção de alegoria, teorizada por Walter Benjamin em 'A Origem do Drama Barroco Alemão', é uma referência substanciosa para os interessados em interpretar fotografias. O esforço de Benjamin por reivindicar a alegoria como forma de expressão (na contramão à tendência de caracterizá-la somente como modo de designação), e 
Fig. 33 Fragmento do monumento a Ramos de Azevedo (A Vitória). Foto: Hugo Zanella. Arquivo: Bronzes Zanélla. Arquivo: Bricos Rebellato.

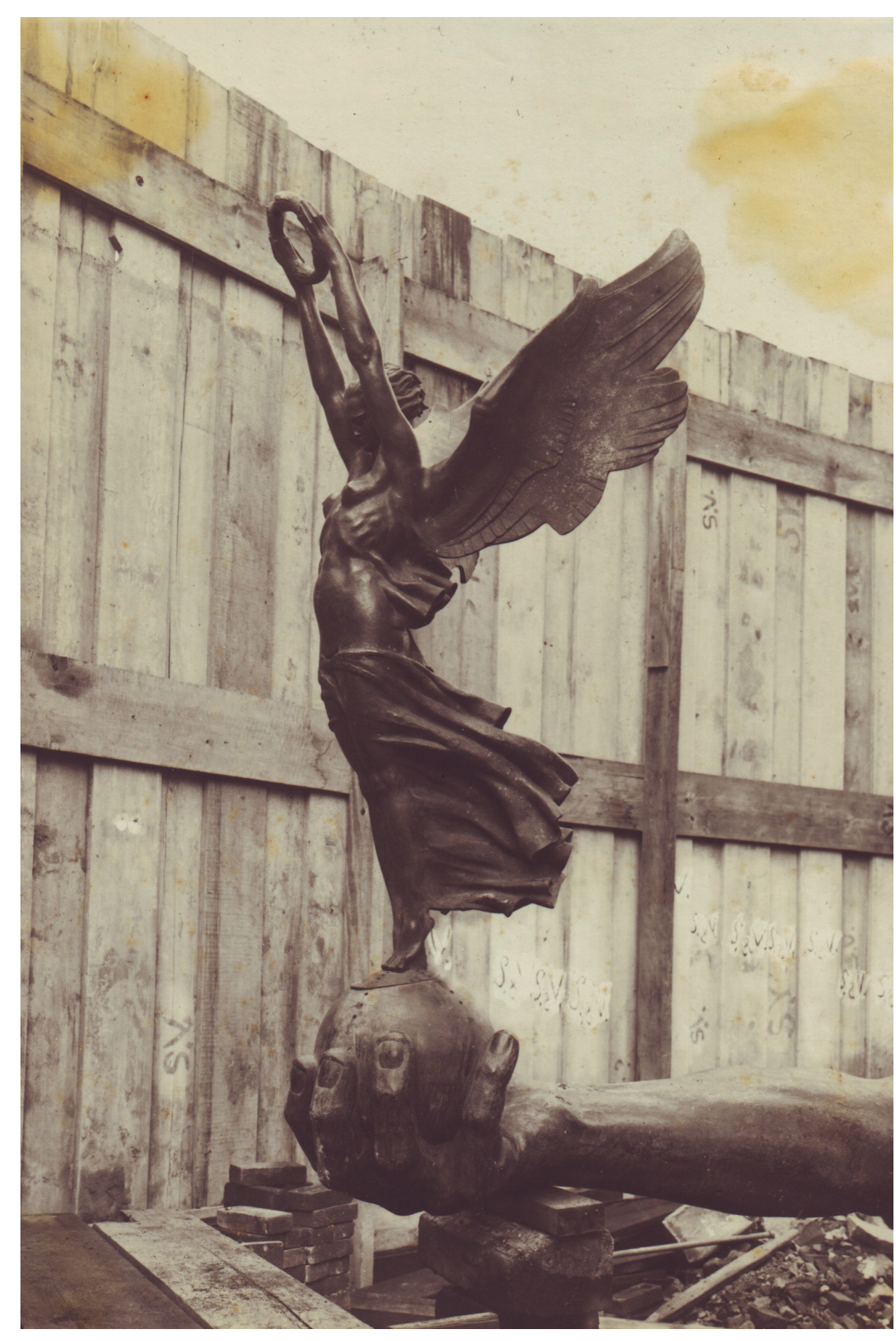

contrapô-la à lógica simbólica, ajudam a pensar na transformação que ocorre sobre o significado do monumento quando este aparece fragmentado.

O símbolo relaciona a parte com a totalidade, gerando a unidade e oferecendo uma impressão global. Cada parte remete à totalidade da obra e, nesse sentido, a independência do fragmento é inexistente. A expressão alegórica, por seu lado, separa os elementos de seus contextos, os isola, revoca-lhes sua função e lhes confere novos sentidos. Estes sentidos dispensam os referentes dos seus contextos originais e são criados articulando diferentes fragmentos entre eles. As costuras da criação de sentido são visíveis, mostram-se como artifício construído e não pretendem harmonizar as partes. A forma de expressão alegórica é inorgânica, articula símbolos vazios.(4)

O símbolo procura comunicar da maneira mais concisa e clara. A alegoria toma posse de idéias alheias e as reproduz como imagens. Sua expressão é ostensiva, ambígua e polissêmica, exibindo uma grande riqueza de significações: "Cada personagem, cada coisa, cada relação pode significar uma outra qualquer ad libitum”.(5) Não mostra nenhuma intenção de clareza e muito menos de estabilidade vinculada a um significado originário.

$\mathrm{Na}$ reprodução fotográfica se percebe a permanência do vestígio de morte, a petrificação de um referente e seu cenário, fundidos em imagem. A significação alegórica está sujeita à caducidade da natureza e por isso sua interpretação da história desenvolve-se a partir de um ponto de vista decadente. A história significa enquanto é algo seco, petrificado, que não pode conter uma essência. 
Uma leitura alegórica da história é feita fragmentariamente, articulando 'ruínas' entre elas, pelo que qualquer interpretação que pretenda gerar sentido a partir delas, não deixa de ser uma construção 'montada' e parcial. Daí que Benjamin enfatize a teatralidade contida na construção histórica e sua fusão com o cenário.

Quem interpreta de maneira alegórica valoriza os intervalos entre as 'ruinas' a serem relacionadas, encontra sentido na falta de unidade: "No campo da intuição alegórica, a imagem é fragmento, ruína [...] A falsa aparência de totalidade se desfaz. O eidos se apaga, a parábola morre, seu cosmos interior resseca. Nos rébus secos que sobram, jaz uma intuição, acessível para o meditativo confuso. Perceber a falta de liberdade, a imperfeição, a caducidade do corpo belo e sensual, era impossível ao Classicismo, pela sua própria essência."(6) Nestas fotos, o monumento entra no fluxo instável do tempo, em uma narrativa fragmentada.

Ramos de Azevedo está sentado sobre uma construção de madeira improvisada (Fig. 35). Parece confortável, realmente compenetrado com o lugar. Dá a impressão que o espaço foi adaptado para recebê-lo e encenar seu retrato. Sobretudo pelo banco e pelas lâminas, colocadas, ao que parece, de maneira a separar o fundo.

Seu rosto dirige-se à câmera, mas seu olhar apagado não repara no mundo material. Tem uma grande planta sobre os joelhos, que se dobra e toca a banca. Seu pé direito apóia-se firmemente sobre o chão

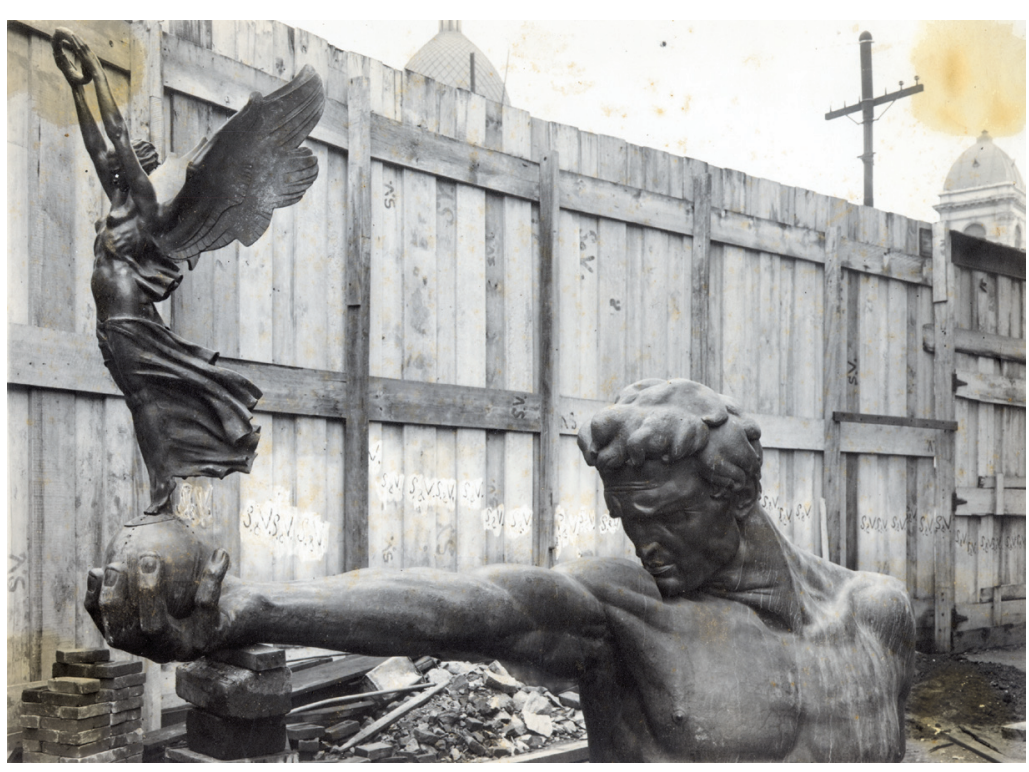

Fig. 34 Fragmento do monumento a Ramos de Azevedo (A Vitória e o Gênio). Foto: Hugo Zanella. Arquivo: Bronzes Artísticos Rebellato. 
Fig. 35 Fragmento do monumento a Ramos de Azevedo (Estátua do Ramos). Foto: Hugo Zanella. Arquivo: Bronzes Artísticos Rebellato.

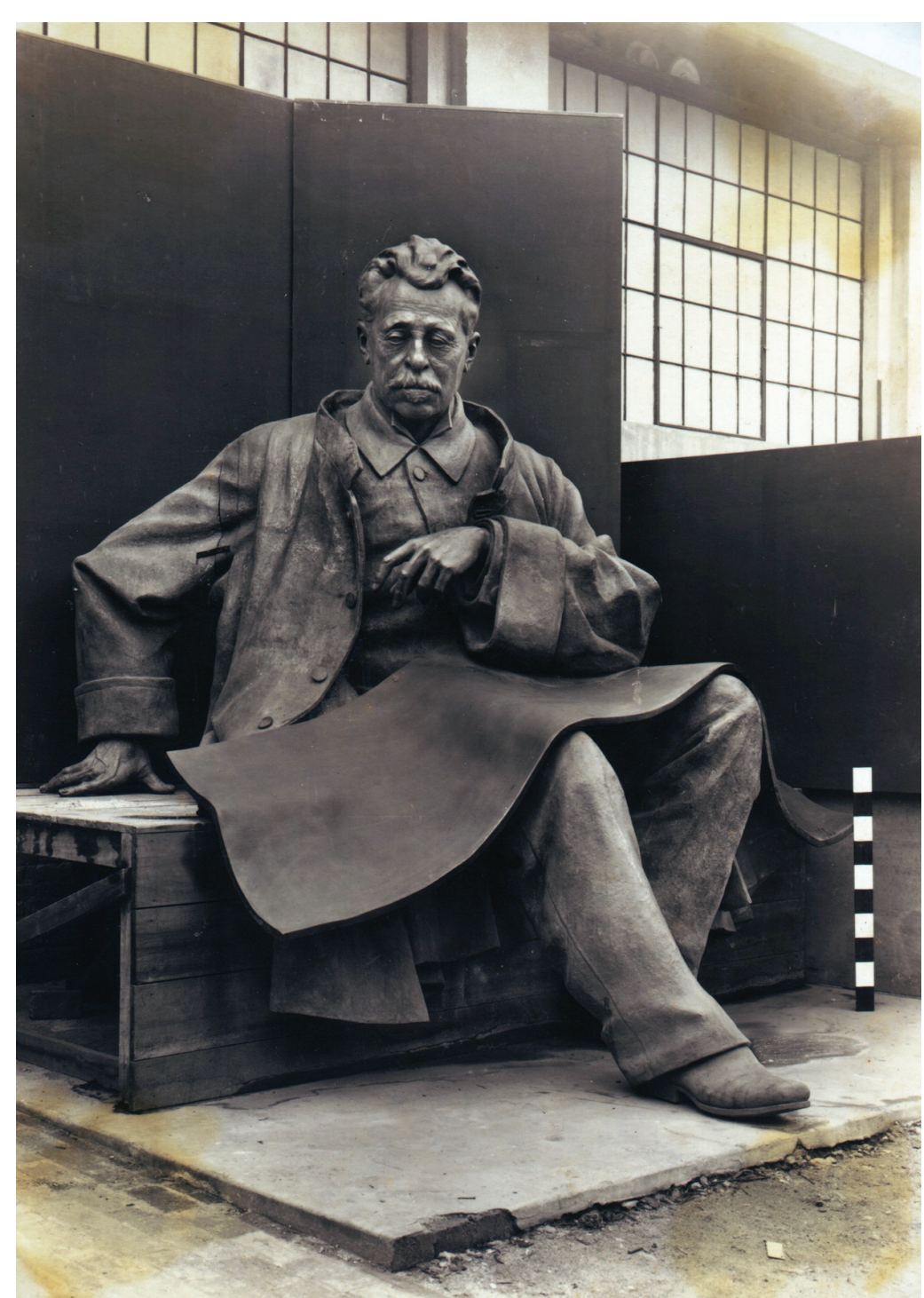

e a mão direita sobre o banco, como que afirmando sua presença no espaço. Parece pensar em algo que consegue captar toda sua atenção. Talvez esteja planejando, talvez lembrando. Julgando pela planta que ele tem sobre os joelhos, diríamos que ele projeta, mas seu olhar nostálgico e perdido nos indica que seu pensamento se ocupa de memórias.

No conjunto do monumento, Ramos de Azevedo é a única figura representada de maneira realista, sem aceder ao repertório idealizado de corpos harmônicos que prescinde do uso de roupas. Sua vestimenta corresponde à vestimenta que um burguês da época usaria. No conjunto, sua estátua é a única representação que corresponde à história social. Representa uma pessoa que existiu historicamente e que foi reconhecida numa sociedade pelas suas ações. Segundo o monumento, ele é a pessoa que planeja e lidera o empreendimento progressista de transformação em São Paulo. Seu instrumento é o plano, e a ação que o identifica é o ato de planejar.

Uma sociedade que planeja, adianta-se ao futuro, tem a capacidade de conduzir seu destino para a frente e organizá-lo desde o presente. A ação planejadora reduz as possibilidades de acidente e de acaso, se posiciona contra a contingência e em favor da ordem. Adianta-se aos fatos com previsão modelando seqüências de eventos. No contexto de São Paulo, o ato planejador de Ramos de Azevedo põe a base e é a condição para a entrada galopante do progresso.

$\mathrm{Na}$ foto, a representação da pessoa responsável por projetar se desvincula da representação do progresso, da representação das artes e da representação do trabalho. Sem as outras peças e perdendo sua po- 
sição privilegiada de guia, na frente do conjunto, a estátua de Ramos de Azevedo adquire uma expressão nostálgica. O ponto de vista da câmera, olhando de frente para o rosto do retratado e deixando aparecer fragmentos do entorno mundano, enfatiza o conteúdo melancólico da imagem.

A pessoa encarregada de projetar, lembra. Por um instante deixa de olhar para a frente e se devolve ao tempo com aflição.

\section{8}

As quatro musas alegóricas posam para o fotógrafo. Arquitetura (Fig. 36), engenharia (Fig. 37), pintura (Fig. 38) e escultura (Fig. 39), individualmente. Pela primeira vez, presto atenção em seus cabelos. Cada uma tem um estilo de cabelo próprio e diferente das outras, mas seguem sendo tão similares... Antes me pareciam irmãs e agora tenho a impressão de que são a mesma pessoa em quatro momentos.

As três primeiras foram fotografadas de maneira a enfatizar a função do registro. As fotos querem ser transparentes, no sentido que se limitam a mostrar o referente da maneira mais clara possível. Cada alegoria está localizada num espaço que não contém nada significativo, mais do que sua presença. As fotos foram tiradas de um ponto de vista que favorece a visão direta e completa das musas, sem interrupções. Ressalta-se o instrumento distintivo de cada uma: compasso, roda de engrenagem e pincéis e paleta.

A intenção do fotógrafo parece ser a de separar individualmente cada alegoria, num impulso de catalogar as peças do monumento.

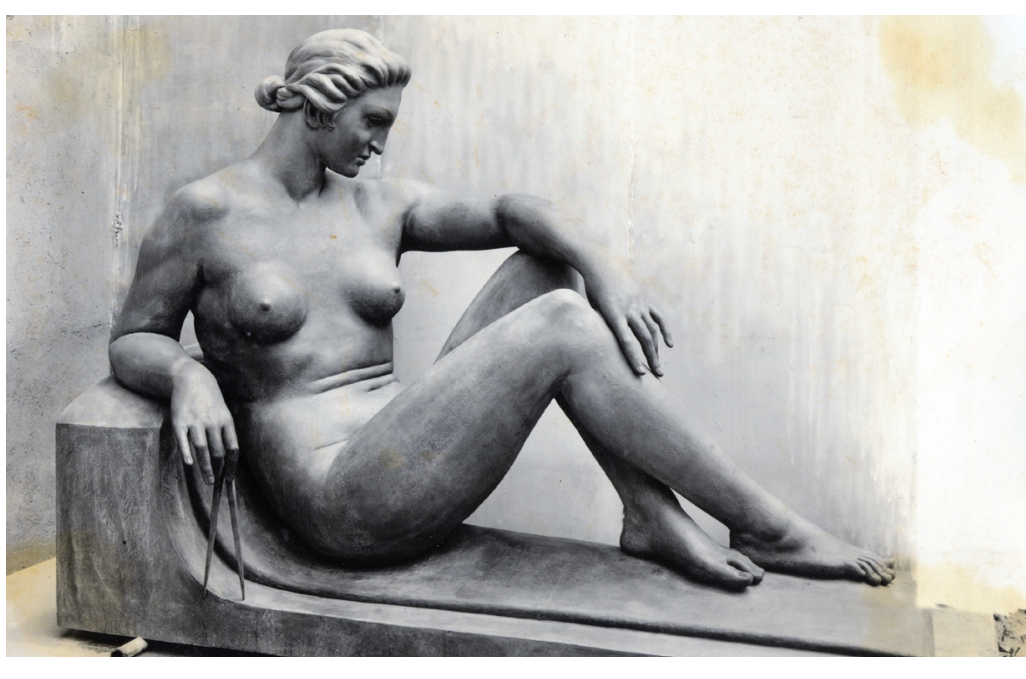

Fig. 36 Fragmento do monumento a Ramos de Azevedo (Alegoria a Arquitetura). Foto: Hugo Zanella. Arquivo: Bronzes Artísticos Rebellato.

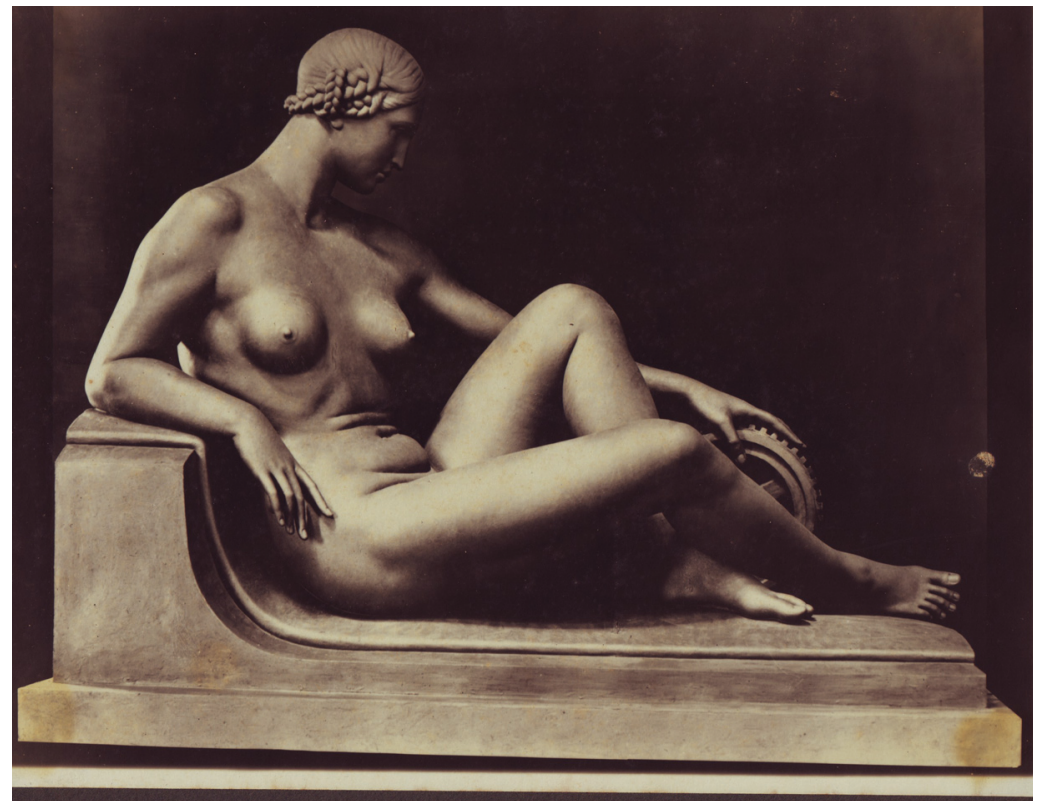

Fig. 37 Fragmento do monumento a Ramos de Azevedo (Alegoria a Engenharia). Foto: Hugo Zanella. Arquivo: Bronzes Artísticos Rebellato. 
Fig. 38 Fragmento do monumento a Ramos de Azevedo (Alegoria a Pintura). Foto: Hugo Zanella. Arquivo: Bronzes Artísticos Rebellato.

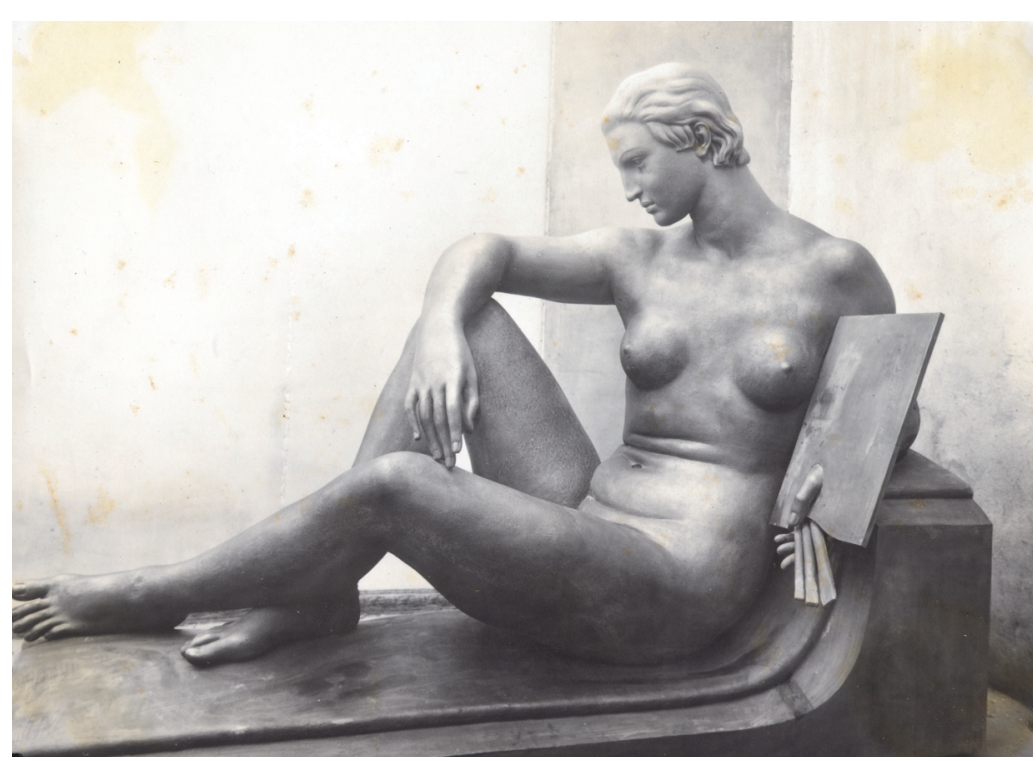

Nestas fotos, como no monumento, as alegorias significam individualmente. Isso é, engenharia, arquitetura e pintura. $\mathrm{Na}$ foto onde aparece a alegoria à escultura, que é a última das quatro, algo acontece que afeta a neutralidade do registro: uma pessoa irrompe na cena no momento exato da foto e interage com a escultura de maneira narrativa. É um homem vestido com roupas de trabalho, está usando macacão e boné. Provavelmente um operário de Bronzes Artísticos Rebellato.

O pano de fundo preparado para a foto é uma superfície lisa, que pode ser parede ou talvez um tecido, ou ainda alguma lâmina firme. $\mathrm{O}$ trabalhador entra em cena por trás, mostra-se aonde a parede termina. Sua imagem está um pouco desfocada, como se houvesse se movido enquanto tiravam a foto. A alegoria permanece sentada sobre uma base reclinada, com as pernas recolhidas, olhando diretamente para o trabalhador e segurando martelo e cinzel, os instrumentos que a caracterizam.

A imagem tem um grande poder de sedução que fixa a atenção do observador. Ocorre uma triangulação entre o olhar do trabalhador, a musa e o observador da foto, que integra a este último à construção visual da cena. Nela, o trabalhador é flagrado pela alegoria enquanto olha para ela, a alegoria é flagrada enquanto olha para o trabalhador e o trabalhador flagra o observador olhando esta cena. Entre os três há uma dependência e uma tensão ativada pelo olhar.

O trabalhador é um voyeur observado, e nós os espectadores também. O lugar privilegiado do observador não nos protege da influência magnética dos outros olhares. Cada personagem da foto olha e é olhado. A foto coloca as condições para que os sujeitos da imagem 


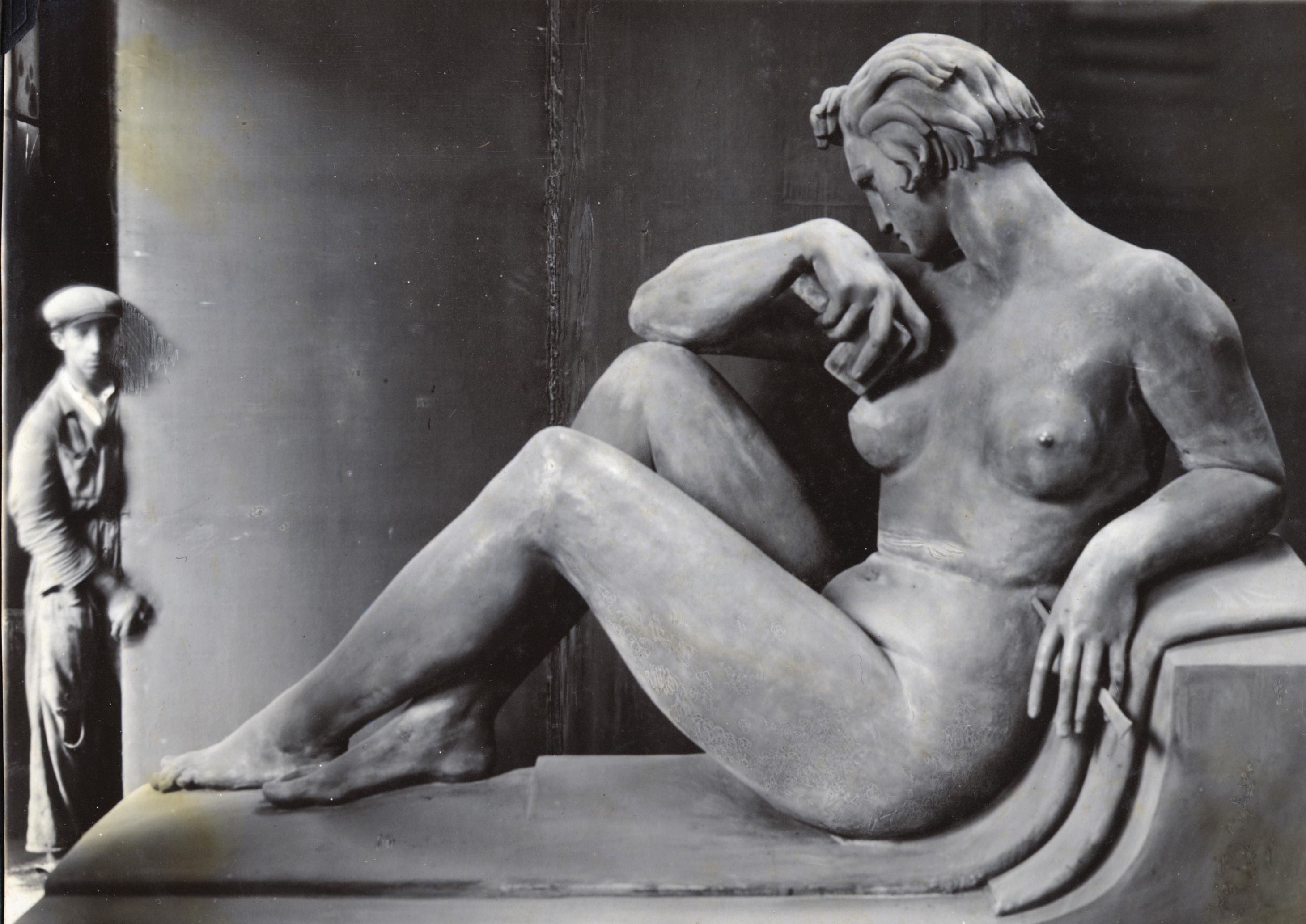


64

Fig. 40 Fragmento do monumento a Ramos de Azevedo (cavalo do grupo O Progresso). Foto: Hugo Zanella. Arquivo: Bronzes Artísticos Rebellato.

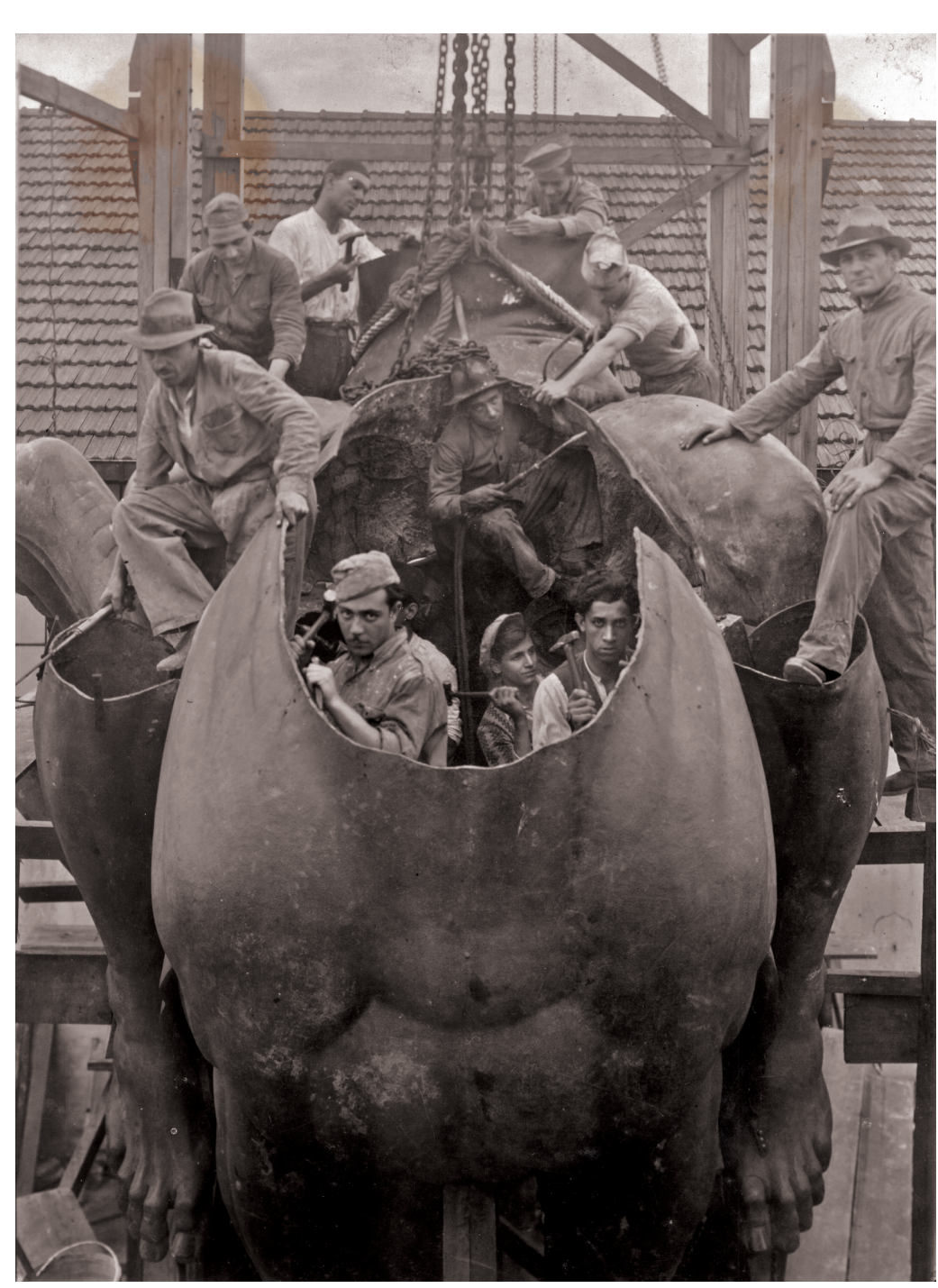

criem aos outros sujeitos pelo olhar e ao mesmo tempo sejam criados pelo olhar deles em um jogo de reflexos.

Seguramente a intenção original desta imagem encenada era representar a atividade do trabalho de maneira positiva (Fig. 40). O trabalho entendido como virtude e valor moral que permite grandes empreendimentos. Há um grupo de trabalhadores usando seus meios de produção na ação de construir uma grande escultura em forma de cavalo. Mas o cavalo não tem cabeça nem cavaleiro para que o guie. Adentro, em seu ventre, há sete trabalhadores visíveis. Há outros pendurados em volta, na superfície externa.

A cena, então, não é tão positiva como aparenta. Os trabalhadores estão construindo o cavalo do 'Progresso' que representará a classe dominante à qual servem. O Progresso, no seu processo de realização, ou melhor, no processo de criação de uma imagem sua, se alimenta do trabalho dos operários. Porém, os trabalhadores dentro do cavalo possibilitam que ele esteja sem cabeça por algum tempo e são cientes do ato fotográfico. Como se soubessem que a foto está dirigida a eles, cientes de estarem sendo retratados, olham de frente para a câmera.

No mito, Perseu derrota a Medusa enfrentando-a através de imagens indiretas. Consegue cortar-lhe a cabeça porque nunca a olha de frente, só de maneira mediada. Perseu coloca seu escudo como intermediário entre seus olhos e os olhos da Medusa, ou seja, a converte em imagem antes de olhar para ela. $\mathrm{O}$ herói vence através da visão indireta. 
Os trabalhadores não vencem, mas deixam o testemunho de estarem cientes de habitar o cavalo. Sabiam que este não tinha cabeça e que eles o transformavam desde dentro. Como se preparassem um cavalo de Tróia por meio da fotografia, que ao contrário de ser uma oferenda, era uma perversão do cavalo original, à deriva, sem cabeça e apropriado por eles. O cavalo petrificado na fotografia como sendo algo diferente de si mesmo.

A fotografia tem sido vinculada reiteradamente com a atividade da caça, assim como o fotógrafo com o caçador. O referente é a presa e a imagem o troféu. Este ato de violência se remonta às origens do aparelho fotográfico, também relacionado a outros aparelhos violentos. Seu modus operandi tem sido interpretado em consonância com aquele da guilhotina. O funcionamento do obturador de uma câmara consiste em se abrir e se fechar em frações de segundo, cortando abruptamente a entrada de luz. A racionalidade mecânica da guilhotina separa o corpo da cabeça.

"Sempre há um homem sem cabeça rondando os imaginários, espreitam os cortadores de cabeças... "Perder a cabeça"é um risco que assalta permanentemente à razão (tão seguramente localizada na cabeça...)".(7) Fica difícil ver a foto do cavalo acéfalo sem pensar no ato de violência contra um tipo de racionalidade e um tipo de empreendimento determinados. Nas palavras do seu criador, o artista Galileo Emendabili, o significado do cavalo é o seguinte:

Está visto que não se trata, aqui, do cavalo comum, fotografado do natural, e sim, como na heráldica, de uma figura estilizada, ampla, cheia de espírito, vigorosa no conjunto e imponente pela sua atitude

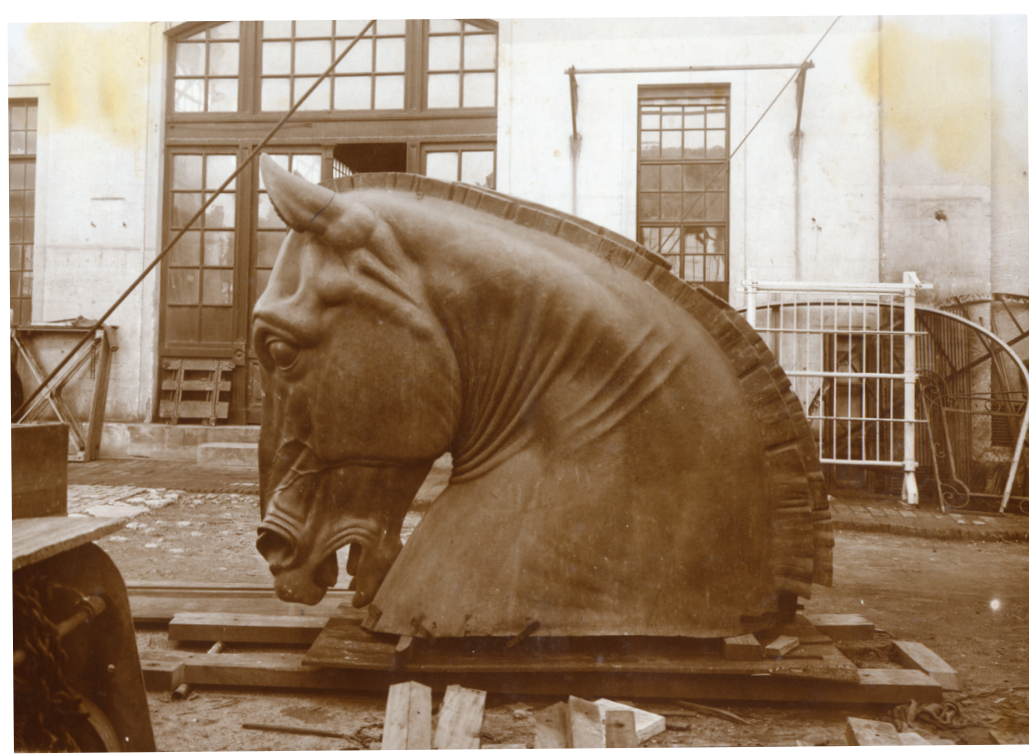

Fig. 41 Fragmento do monumento a Ramos de Azevedo (cavalo do grupo O Progresso). Bronzes Artísticos Rebellato. 
Fig. 42 Fragmento do monumento a Ramos de Azevedo (grupo Os Construtores). Foto: Hugo Zanella. Arquivo: Bronzes Artísticos Rebellato.

Fig. 43 Fragmento do monumento a Ramos de Azevedo (grupo O Progresso). Foto: Hugo Zanella. Arquivo: Bronzes Artísticos Rebellato.
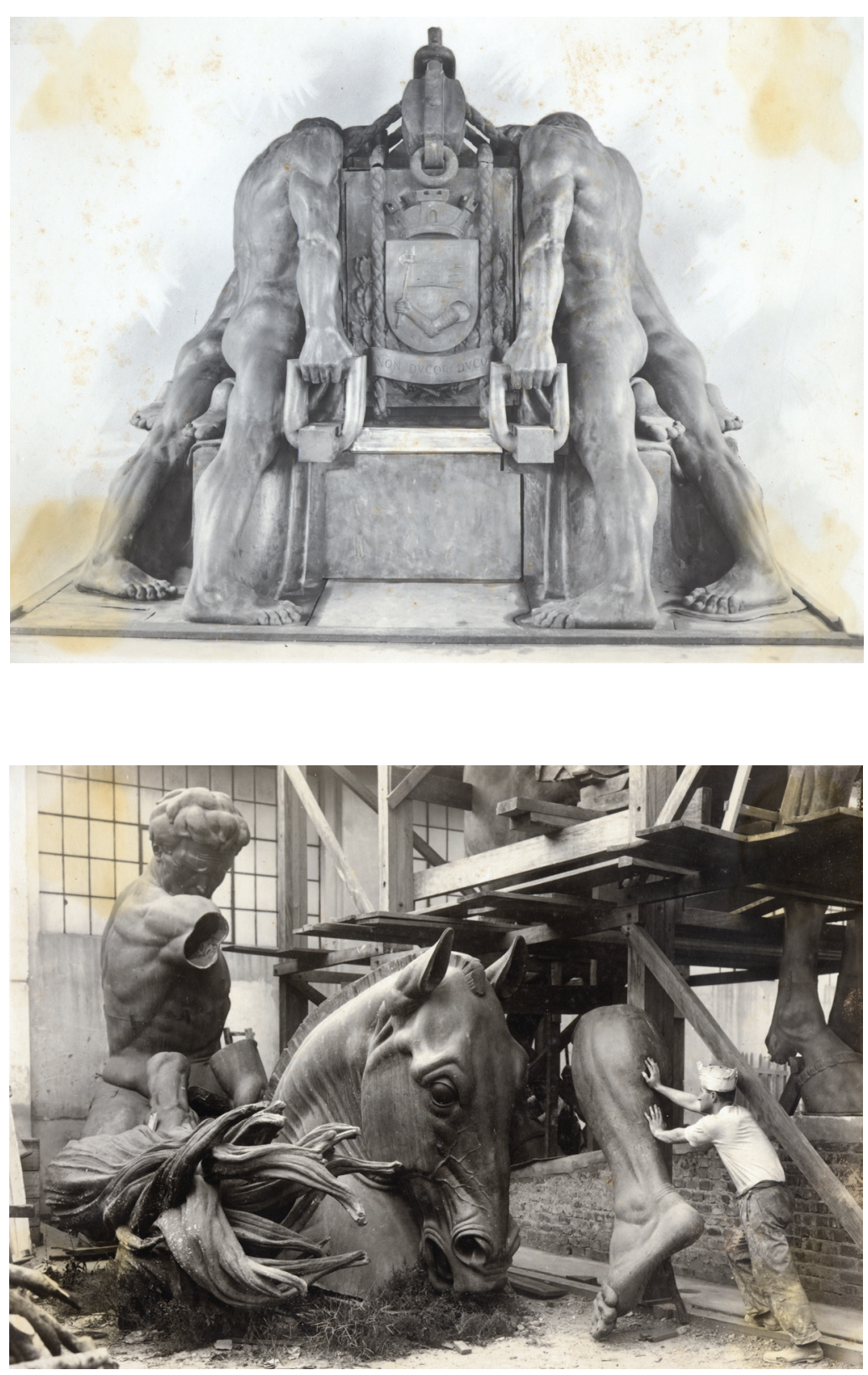

dominante. Pus-lhe asas para significar mais claramente a sua função pura de símbolo, e também no intuito deliberado de expressar que, entre os progressos das cidades, o de São Paulo, que não pode ser desligado do nome de RAMOS DE AZEVEDO, foi mais rápido, mais dinâmico, mais decisivo do que todos os outros.(8)

Emendabili vincula a maneira idealizada com a qual representa o cavalo, com a ideologia progressista que determinou a reestruturação de São Paulo de finais do século XIX e começos do século XX, e com a transparência expressiva do símbolo. É significativo que seu discurso enfatize que não se trata de um cavalo fotografado, o que para ele seguramente significava 'real' e por isso, comum. $\mathrm{Na}$ fotografia em questão, o símbolo do 'Progresso' se transforma em uma alegoria pervertida do trabalho. O cavalo acéfalo do 'Progresso' tem o ventre cheio de trabalhadores.

\section{0}

No álbum há outras representações do trabalho. Há a alegoria que representa o trabalho no monumento (Fig. 42), separada do resto da obra e fotografada individualmente, além de duas fotografias que mostram cenas dos trabalhadores de Bronzes Artísticos Rebellato fundindo as partes do monumento e outra de um trabalhador deslocando um fragmento do monumento (Fig. 43).

$\mathrm{Na}$ primeira, se aprecia a estátua que representa quatro trabalhadores de corpo idealizado, na ação de empurrar uma máquina. Esta tem inscrito o brasão do Estado de São Paulo na parte posterior, com 
a legenda em latim: 'Non Ducor Duco' ('Não sou conduzido. Conduzo'). A foto foi tirada de trás, de um ponto de vista central. Vê-se os trabalhadores de costas, indo para a frente, movimento que se enfatiza pelo ponto de vista que conduz as figuras para dentro da imagem. Os trabalhadores operam em conjunto ditando a direção da máquina, conduzindo-a. Para onde?

Fora o conjunto alegórico, a foto não mostra mais informação. Em volta só branco, seu contexto é abstrato. No conjunto monumental, o grupo de trabalhadores está localizado na base, colocados como guardiōes dos fundamentos do 'Progresso'. Neste contexto, esforçamse empurrando a máquina do progresso, na retaguarda do conjunto, impulsionando-o com sua força de trabalho. A direção é para o futuro, para os limites da cidade, marcando o caminho a se seguir.

Nesta fotografia, o lema do brasão continua sendo central: os trabalhadores conduzem. As variações de sentido se dão por causa do lugar para onde estão indo e na companhia de quem. Se no conjunto do monumento impulsionam as outras figuras, possibilitando o movimento do 'Progresso', na fotografia estão sozinhos. Em seu lugar de origem, o caminho demarcado pelo monumento é o futuro. Ainda que o futuro não estivesse definido, o caminho que levava em sua direção estava sendo construído com toda determinação. A direção da cidade era clara. $\mathrm{Na}$ foto, não há um horizonte a ser alcançado e a direção do movimento é incerta porque não existe nenhum referente que permita uma localização. $\mathrm{O}$ espaço da foto é abstrato, não representa lugar algum. Nele, tudo é indiferenciado.

Os trabalhadores se encaminham solitários para a indetermi- nação do vazio. $\mathrm{O}$ esforço isolado é inócuo porque não incide sobre algo efetivo nem se dirige a lugar algum. A perspectiva convergente encaminha as figuras para um espaço idealizado. Os trabalhadores entram no horizonte abstrato da foto, onde o trabalho não parece ter nem fundamento nem consequiências. Poderíamos ainda dizer que esta imagem pode ser interpretada como uma alegoria do trabalho abstrato.

Em outra foto (Fig. 43), aparece um trabalhador capturado enquanto desloca um fragmento de uma das pernas do 'Gênio'. Sua ação consiste em empilhar peças do grupo do 'Progresso' em um canto. O lugar do acontecimento tem o aspecto de um armazém. $\mathrm{O}$ torso do 'Gênio', a cabeça do cavalo, seu rabo e duas peças que parecem ser parte das asas do cavalo estão amontoadas e se sobrepõem aleatoriamente entre si. Estão colocadas sobre um piso coberto de galhos, talvez de erva seca, que lembra a superfície dos Presépios. À direita, uma estrutura de madeira com base de tijolo e cimento guarda outras partes do monumento, das quais só se reconhecem duas das pernas do cavalo.

A imagem não deixa de ter um ar surrealista. Fragmentos de uma obra de arte nobre, sobrepostos como um delicioso cadáver, numa espécie de Presépio macabro. $\mathrm{O}$ trabalhador parece estar sob o domínio do olhar do 'Gênio'. Em relação às peças, está na escala de um brinquedo vestido de trabalhador. Está na mesma posição das figuras que representam o trabalho no monumento, empurrando para a frente, também impulsionando o 'Progresso'. Só que nesta imagem o 'Progresso' está fragmentado, empilhado num canto, sobreposto e incompleto. A imagem integra o trabalhador com as figuras do grupo 
Fig. 44 Fundição do monumento a Ramos de Azevedo. Foto: Hugo Zanella. Arquivo: Bronzes Artísticos Rebellato.

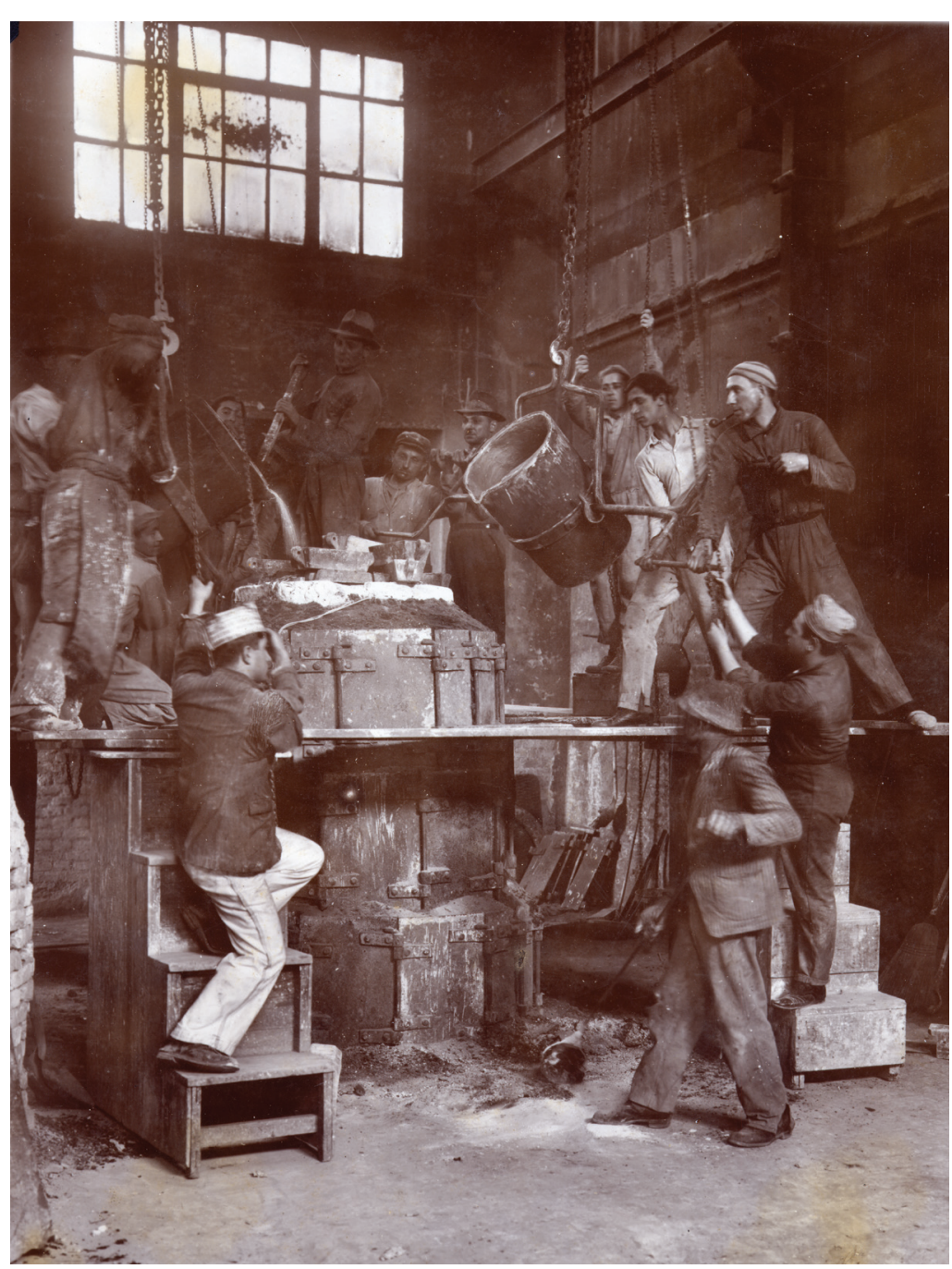

do 'Progresso' em um cenário tumular onde a representação se alinha à vida comum. Ou será a vida comum que se alinha ao lugar da representação?

As duas fotos onde aparecem os trabalhadores de Bronzes Artísticos Rebellato no processo de fundição do monumento (Fig. 44), remetem a cenas de época pintadas. Não posso evitar de fixar minha atenção no personagem com cigarro na boca em uma, e o personagem com cachimbo e gorro na outra. Os trabalhadores posam em situação de trabalho. Vejo estas fotos como simulacros do trabalho, afastadas da ação em tempo real. O processo encenado.

O que me interessa ressaltar é que estas representações do trabalho foram realizadas sem a necessidade de 'trabalho' no ato de sua elaboração. Que o tipo de trabalho que representam, que envolve esforço físico, atividade manual, enfrentamento com material, infraestrutura industrial, etc., não coincide com o modo de produção da imagem resultante. As personagens das fotos estão produzindo uma escultura e para isto usam suas mãos, sua força e suas ferramentas. $\mathrm{O}$ fotógrafo que realiza a imagem deste processo enquadra e aperta um botão. Walter Benjamin explica esta mudança na forma de produzir imagens de maneira fisionômica: "Pela primeira vez no processo de reprodução da imagem, a mão foi liberada das responsabilidades artísticas mais importantes, que agora cabiam unicamente ao olho. Como o olho apreende mais depressa do que a mão desenha, o processo de reprodução das imagens experimentou tal aceleração que começou a situar-se no mesmo nível que a palavra oral.”.(9) 
Em 'Outros Critérios', ao discorrer sobre o caráter utilitário de origem puritano da cultura artística norte-americana que, segundo ele, "deriva de uma postura inicial de repúdio [à arte]"(10), Leo Steinberg (1920-) remonta à obra de Thomas Eakins e sua vinculação da arte ao Trabalho. Realmente só se refere à pintura 'William Rush Esculpindo sua Figura Alegórica do Rio Schuylkill' (1918), e a compara com 'Pigmalião e Galatéia’ (1890), do seu antigo professor francês Jean-León Gérôme. Segundo Steinberg, a diferença básica entre ambos quadros reside em que o artista francês associa a arte ao desejo, e o norte-americano redime a arte na atividade do trabalho:

O nu no quadro de Eakins é um dos mais delicados da pintura norteamericana. Mas pode-se observar que a alegoria para a qual o modelo posa está vestida; portanto, a nudez do modelo não está lá para o deleite, mas para a ciência; a nudez, conforme podemos perceber, é a estrutura que está por baixo dos panos. E, à medida que o escultor cinzela o lado de um joelho de madeira, todos desviam os olhos da mulher nua, até a terceira pessoa presente - uma acompanhante de idade madura debruçada sobre seu tricô. Toda atividade, a paciência do modelo, assim como o ofício do escultor, é redimida pela absorção no trabalho. Seu efeito enobrecedor supera o mais arraigado preconceito. William Rush de Eakins é uma tentativa resoluta de neutralizar a objeção norteamericana à arte e ao nu assimilando ambos à ética do trabalho.(11)

E a maneira como Eakins o faz deixa à vista os traços do processo de produção, se mostra como atividade específica de uma disciplina profissional, que com o uso de pintura foi realizada pela mão do pintor. As imagens dos trabalhadores de Bronzes Artísticos Rebellato não buscam redenção no trabalho. Querem simulá-lo.
$\mathrm{O}$ álbum termina com quatro fotos horizontais, que compartilham um estado temporal ambíguo. São paisagens em processo, em situaçōes instáveis. Se trata do momento de construção dos fundamentos do monumento. Em três delas, vemos trabalhadores em ação. São reconhecíveis o colégio Arquidiocesano e o edifício do Liceu de Artes e Ofícios. As imagens do processo de construção da base estrutural do monumento se assemelha a cenários em ruínas. Ruinas às avessas, para ser exatos.

Este termo foi usado pelo artista norte-americano Robert Smithson no seu relato-guia 'Um Recorrido pelos Monumentos de Passaic, Nova Jersey', para se referir ao estado temporal generalizado dessa paisagem suburbana. Em Passaic, Smithson se encontra com o cenário desolado e entrópico de um passado industrial, ou panorama zero próprio de uma situação desierarquizada, sem qualidades, sem foco nem direção. A capacidade de evocação dessa paisagem ruinosa difere daquela da ruína romântica por não sugerir nenhum sentimento de tipo nostálgico, nem segue sua direção retrospectiva. Permite a articulação de uma noção espaço-temporal entrópica, em torno de 'provas materiais' de defasagens e entrecruzamentos:

Esse panorama zero parecia conter ruinas às avessas, ou seja, toda construção que finalmente se construiria. Isso é o contrário da 'ruína romântica', porque os edifícios não caem em ruínas depois de terem sido construídos, senão que alcançam o estado de ruína antes de serem construídos. Esta posta em cena antirromântica sugere a idéia desacreditada do tempo e muitas outras coisas "defasadas".(12) 
Fig. 45 Fundações do monu-
mento a Ramos de Azevedo. Foto: Hugo Zanella. Arquivo: Bronzes Artísticos Rebellato.

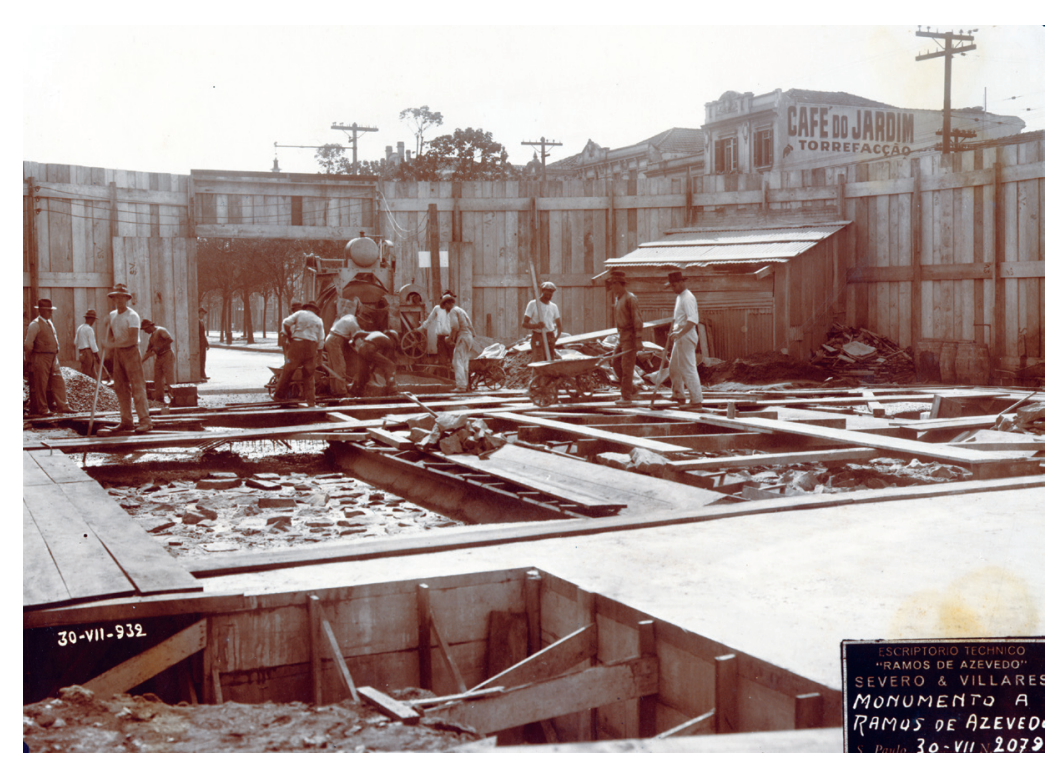

Fig. 46 Fundaçóes do monumento a Ramos de Azevedo. Foto: Hugo Zanella. Arquivo: Bronzes Artísticos Rebellato.

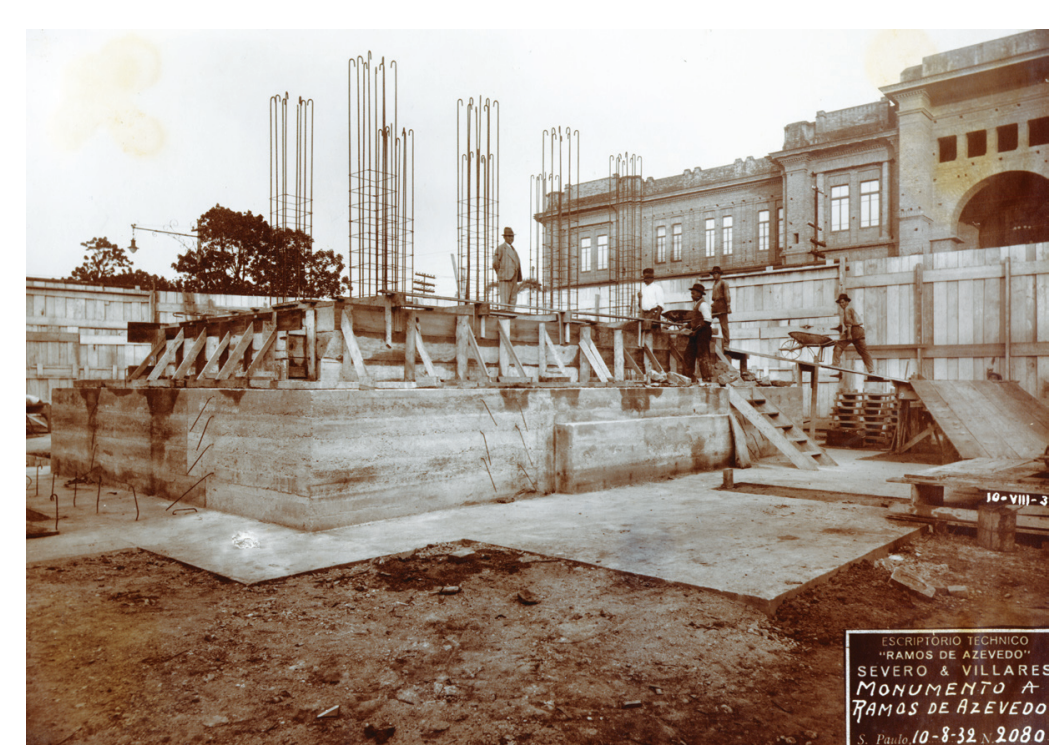

O que se vê nas quatro fotos da construção dos fundamentos do monumento evoca uma situação entrópica similar, onde o tempo bem poderia estar indo para atrás ou para a frente. $\mathrm{O}$ momento no qual o monumento é representado é anterior a sua instalação efetiva na paisagem. Vemos uma 'cena do processo', não vemos a imagem conclusiva. Trabalha-se para chegar ao estado que permita ver o monumento como imagem fundadora. $\mathrm{O}$ antes e o depois do monumento na Avenida Tiradentes não indicam. São momentos sem qualidade, sem foco, sem evento.

O conceito de entropia tem sua origem na área da termodinâmica, é seu segundo principio. Mede a quantidade de energia que não pode ser transformada em trabalho num sistema dado. Dentro de um sistema termodinâmico fechado, o grau de entropia total tende a aumentar com o tempo e a energia a se extinguir. Um exemplo ilustrativo disso é um copo com gelo derretendo. Por isso, o conceito de entropia tem sido utilizado para se referir a situaçōes que tendem à desordem, à dissolução de hierarquias e em última instância à indiferenciação total.

Se pensarmos na situação atual do monumento a Ramos de Azevedo na Cidade Universitária, lugar no qual perde seus referentes históricos, o grupo de fotos ao qual tenho me referido pode ser interpretado como sinal premonitória. Ruínas de algo que ainda não tinha se construído. Ruinas às avessas. Como no copo com gelo, o monumento na Cidade Universitária perde suas qualidades singulares e sua capacidade de narrar. 
Por outro lado, este grupo de fotos também representa o trabalho, e uma leitura alegórica delas se afasta dos valores positivos e educadores próprios de uma visão progressista. Aqui o trabalho não gera uma imagem estável. $\mathrm{O}$ trabalho está em processo e é representado como uma atividade inconclusa e instável. Não está dirigido a uma finalidade e não cria imagem. $\mathrm{O}$ trabalho se confunde com a entropia.

As mesmas peças que no monumento, entendido como unidade simbólica e localizado em seu lugar original, representam o progresso, ao serem alegorizadas na fotografia, pervertem as intençôes originais. O paradoxo reside em que a vontade classificadora e positivante do álbum possibilite uma leitura inversa à do registro.
1. MALRAUX, André, 'The Voices of Silence', tradução ao inglês de Stuart Gilbert, Princeton University Press, Princeton, 1978, pg. 44. (Tradução minha).

2. Ver os capítulos Monumetria: O Projeto, e Trabalho Inacabado, Trabalho Compartilhado: Um Relato.

3. BARTHES, Roland, 'A Câmara Clara: Nota Sobre a Fotografía', tradução de Júlio Castaño Guimarães, Editora Nova Fronteira, Rio de Janeiro, 1984, pg. 139.

4. Para uma interpretação alegórica da obra de arte de vanguarda baseada nas reflexōes de Benjamin, ver: BURGUER, Peter, 'Teoria da Vanguarda', tradução de Jose Pedro Antunes, Cosac \& Naify, São Paulo, 2008

5. BENJAMIN, Walter, 'Alegoria e Drama Barroco', in 'Walter Benjamin: Documentos de Cultura, Documentos de Barbárie (Escritos Escolhidos)', seleção e apresentação de Willi Bolle, Cultrix: Editora da Universidade de São Paulo, São Paulo, 1986, pg. 29.

6. BENJAMIN, Op. Cit.pg. 30.

7. RESTREPO, José Alejandro, 'Cuerpo Gramatical: Cuerpo, Arte y Violencia', Ediciones Uniandes, Bogotá, 2006, pg. 40.( Tradução minha)

8. FABRIS, Annateresa, 'Monumento a Ramos de Azevedo: Do Concurso ao Exílio', Mercado de Letras, São Paulo, 1997, pg. 38.

9. BENJAMIN, Walter, 'A Obra deArte na Era de sua Reprodutibilidade 
Técnica', in 'Walter Benjamin; Obras Escolhidas; Magia e Técnica, Arte e Politica', Editora Barsiliense, São Paulo, 1996, pg. 167.

10. STEINBERG, Leo, 'Outros Critérios: Confrontos com a Arte do Século XX’, Cosacnaify, São Paulo, 2008, pg. 81.

11. STEINBERG, Op. Cit., pg. 84.

12. SMITHSON, Robert, 'A Tour of the Monuments of Passaic, New Jersey' in: FLAM, Jack, 'Robert Smithson: The Collected Writings', University of California Press, Berkeley, Los Angeles, 1996, pg. 72. (Tradução minha). 


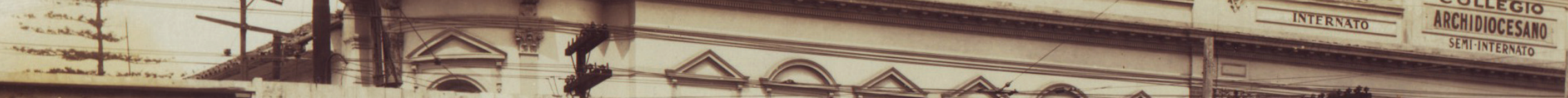

$-4$

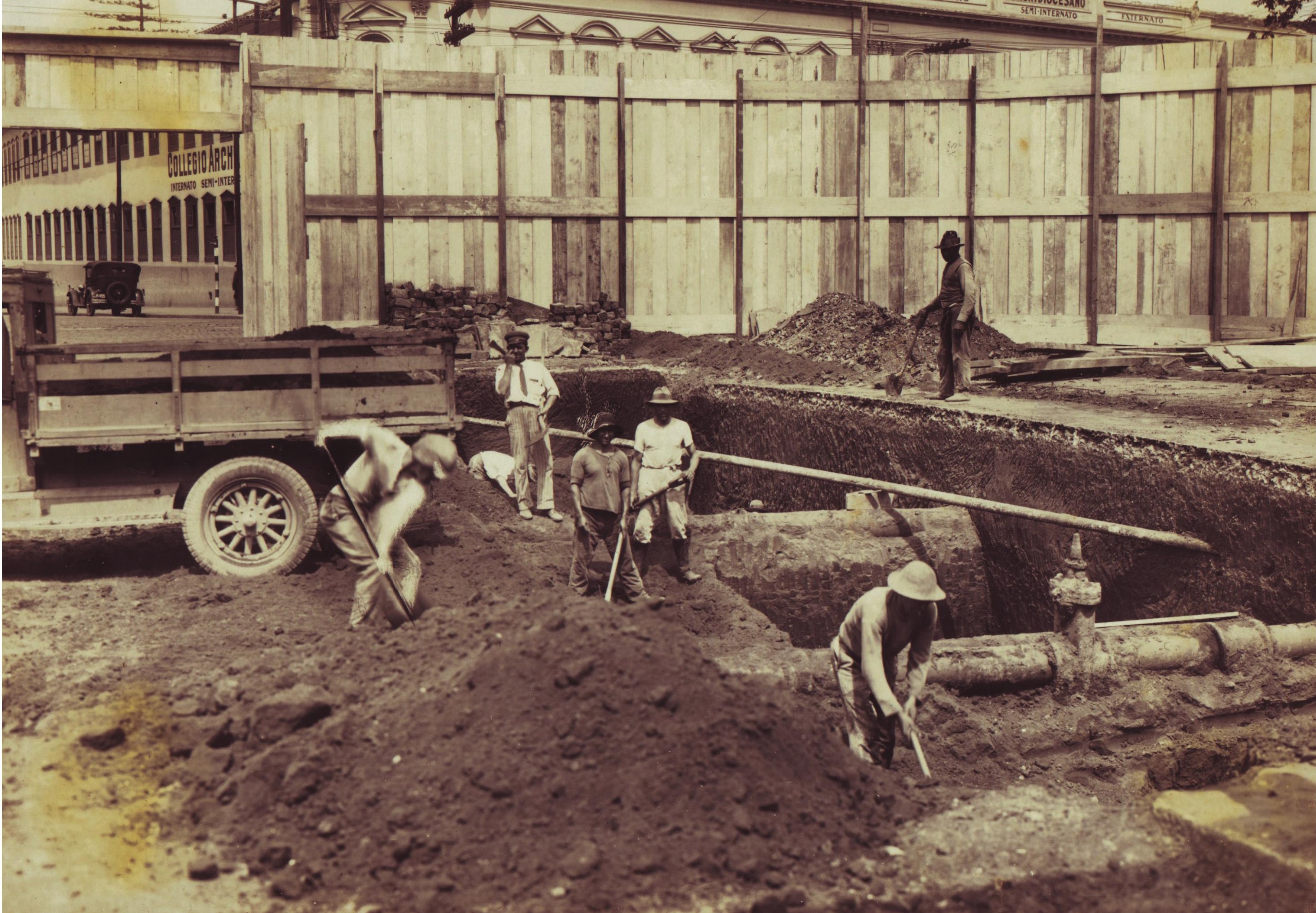



monumetria: o projeto 


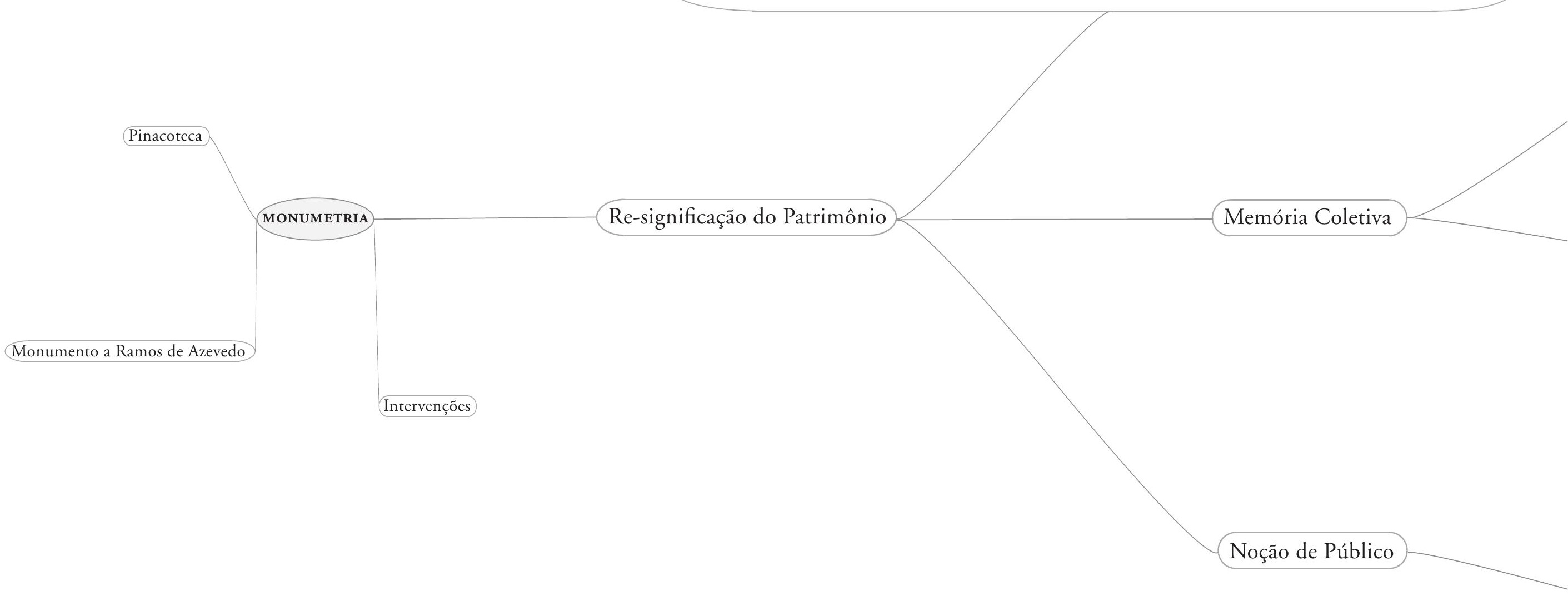

A proposta principal do projeto é o questionamento e a re-significação do patrimônio histórico e cultural mais diretamente ligado à produção artística, seus desdobramentos na produção de memória, ou seja, os espaços criados para sua circulação e arquivo. Ativar, através da releitura do monumento a Ramos de Azevedo, de documentos, de outros registros relacionados e de obras pertencentes ao acervo da Pinacoteca, novas posibilidades de significação. Estas releituras, que constituem novas obras, articulam questões acerca da especificidade das obras em relação ao seu espaço de origem e de seus novos espaços de apresentação e circulação. 
Por meio destas operaçôes, questionar a elaboração da memória coletiva lida como registro histórico, pensada para um espaço público especificamente urbano, e seu diálogo com o espaço museológico institucional também enquanto produtor de memória.

Segundo Le Goff, para a ciência da história, a memória coletiva tem dois tipos de materiais: documentos e monumentos. O monumento se liga à perpetuação das sociedades históricas, enquanto que o documento se apresentaria de forma mais transparente, possibilitando uma leitura mais clara.

Tendo o monumento a Ramos de Azevedo como ponto de referência, ou matéria-prima, esta seqüência de obras se dá na própria linguagem ou meio da documentação, reprodução e canais de difusão. Utiliza material didático, fotografia e texto interligados e se apropria dos canais de difusão como lugares da obra, abdicando da idéia de registro distanciado e assumindo seu caráter criativo.

\footnotetext{
Todas as instâncias e elementos do patrimônio envolvidos no projeto (monumento, documento, museu, projeto arquitetônico, obra de arte) são entendidos em sua concepção própria de espaço público. A proposta, como espaço de encontro entre múltiplas noções do público, estabelece uma discussão fundamentada no choque de fluxos provenientes de âmbitos e níveis heterogêneos, colocando os atores deste espaço no centro do conflito, como seus ativadores.
} 


\section{Pinacoteca}

Monumento a Ramos de Azevedo 
METRIA 


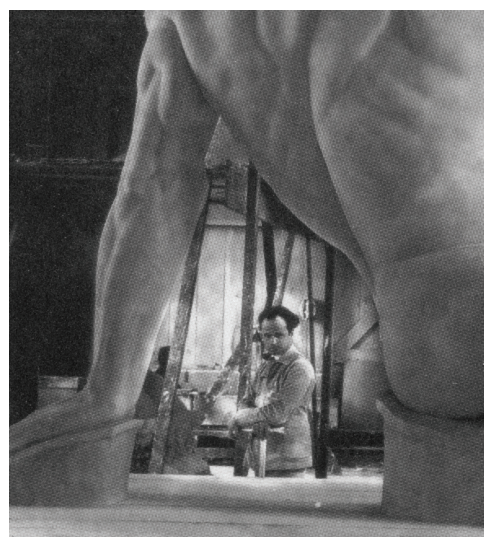

artista Galileo Emendabili trabalhando no Monumento a Ramos de Azevedo, s.d. Foto: Hugo Zanella. Arquivo: Bronzes Artísticos Rebellato

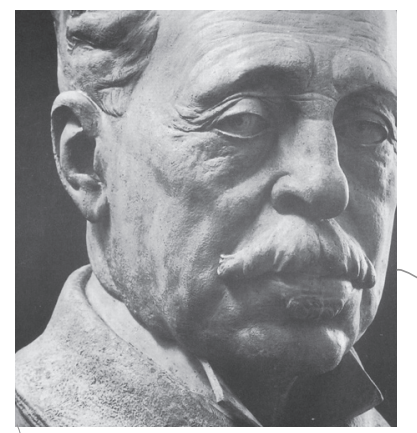

Francisco de Paula Ramos de Azevedo

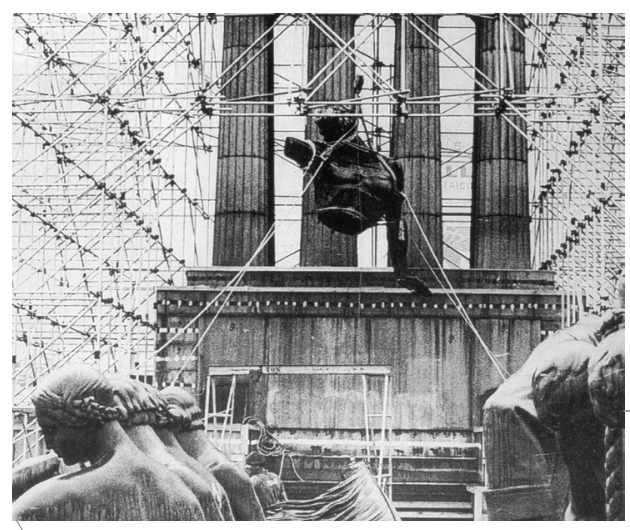

Remoção de $O$ Gênio, 1967. Foto: Hugo Zanella. Arquivo: Silvana Brunelli

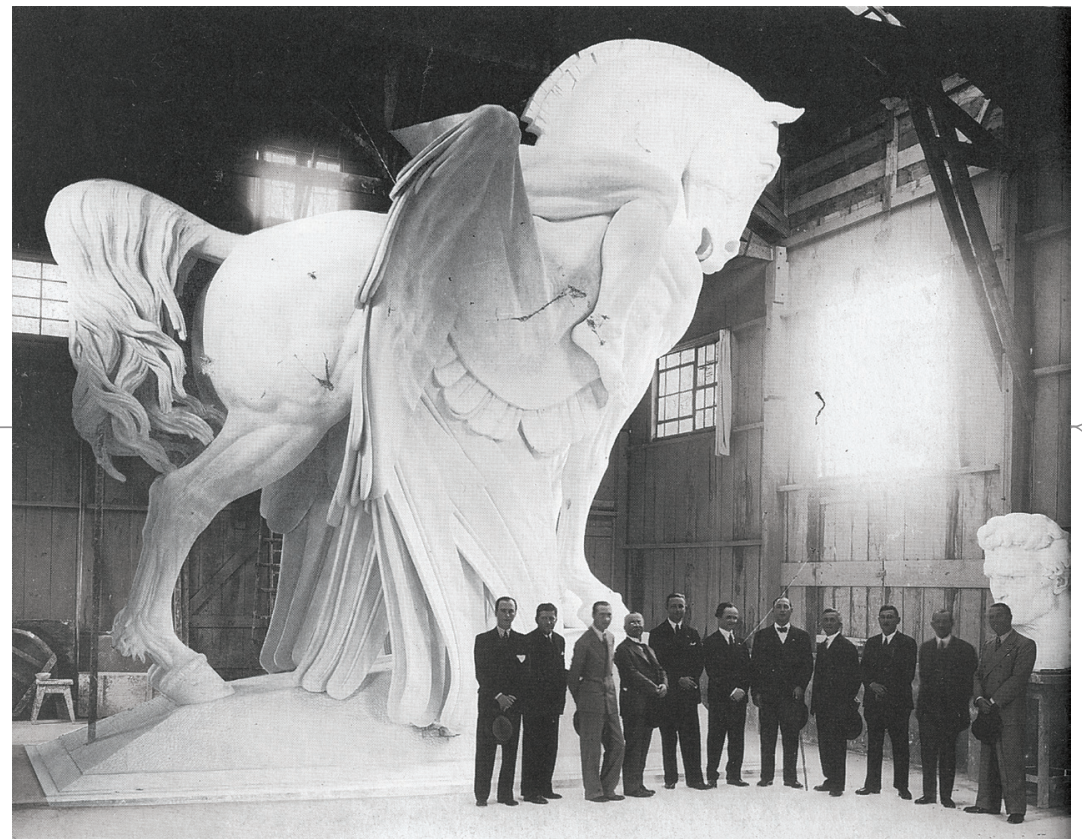

Galileo Emendabili e membros do Comitê Pró-Monumento a Ramos de Azevedo junto a detalhes em gesso do grupo $O$ Progresso, s.d. Foto: Hugo Zanella. Arquivo: Fiammetta Emendabili
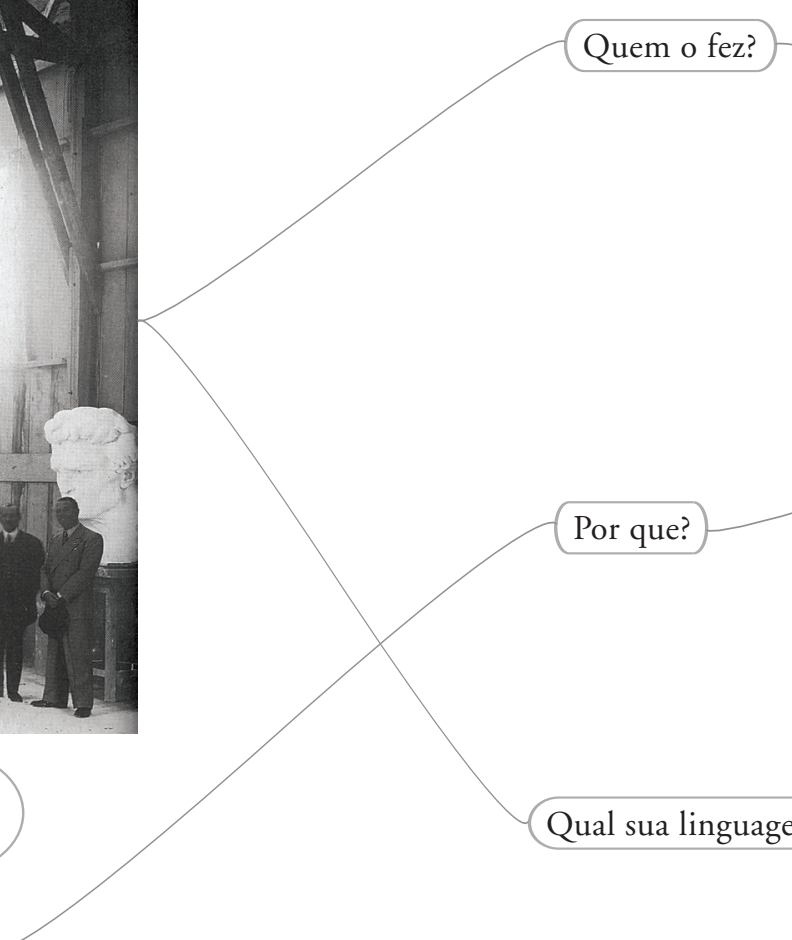

"Fator determinante da construção de um monumento como aquele dedicado a Ramos de Azevedo é a vontade de memória de um grupo que, no final da década de 20, se funde com a vontade de memória de uma comunidade. Esta fusão [...] não é ditada pelo acaso ou por uma determinação puramente emocional. Deriva antes de um projeto ideológico preciso, articulado em volta da noção de progresso, isto é, em volta de um tempo dividido em duas metades, um "antes" e um "depois", dentro do qual Ramos de Azevedo exerce o papel mítico do fundador.”

Annateresa Fabris, 'Monumento a Ramos de Azevedo; Do Concurso ao Exílio', Mercado de Letras, Campinas, 1997

Em 25 de novembro de 1967 tiveram início os trabalhos de desmontagem do monumento a Ramos de Azevedo depois de discussões públicas começadas na década de 50 nas quais, ao dizer de Annateresa Fabris, o monumento foi encarado como estorvo. Coube à administração Faria Lima tomar a decisão. As duas justificativas principais foram o desafogamento do trânsito entre Centro e Zona Norte, que era interrompido pelo monumento assentado na avenida Tiradentes, e a construção da linha de metrô Santana-Jabaquara, que estava planejada para passar no mesmo local. 

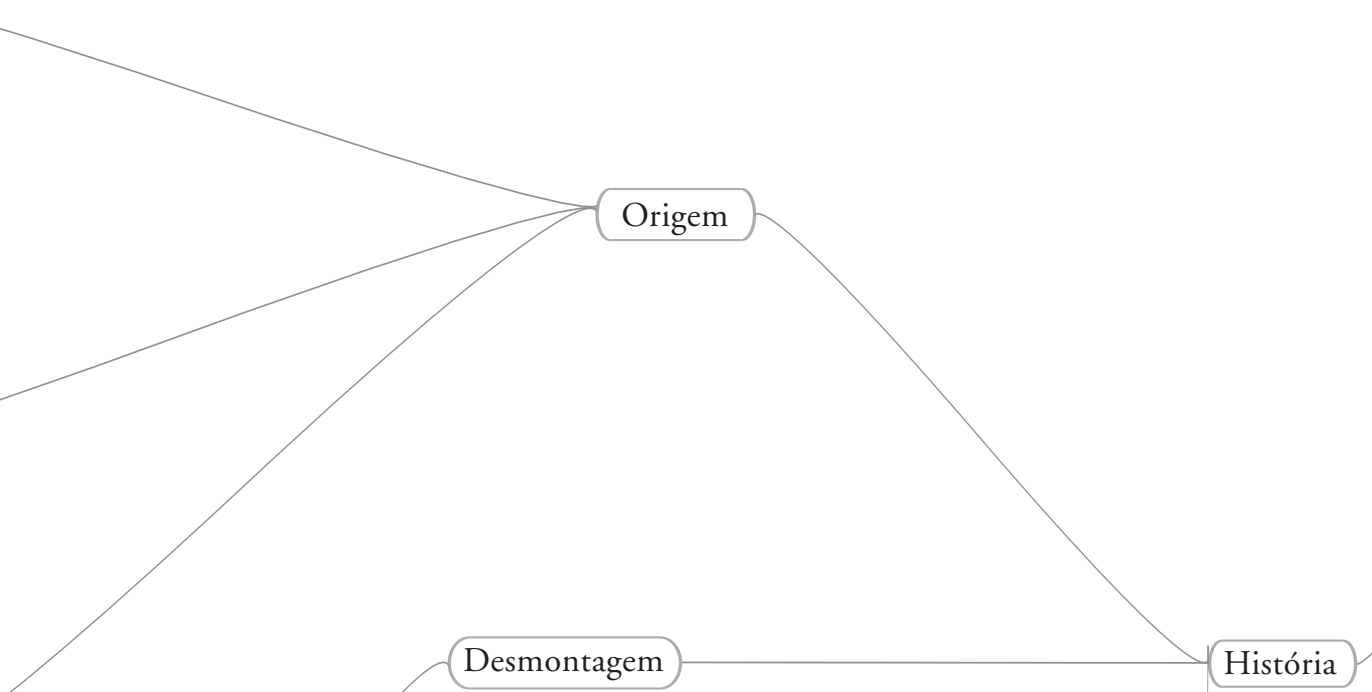

Monumento a Ramos de Azevedo

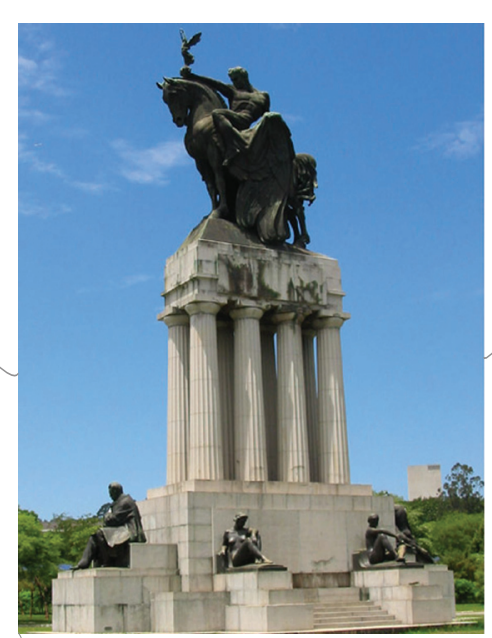

Atualidade

Monumento a Ramos de Azevedo na Cidade Universitária, 2007, autor desconhecido 
Estes meios, tradicionalmente utilizados para arquivo, reprodução, e difusão das obras, são os próprios meios de existência das releituras do patrimônio desenvolvidas pelo projeto. A idéia básica é encarar os procedimentos e técnicas de arquivo, reprodução e difusão como meios criativos, capazes de re-significação e reativação tanto de obras pertencentes ao acervo, como do monumento a Ramos de Azevedo.

Todas as intervenções utilizam material de arquivo e estabelecem uma relação visível entre o espaço de exibição e o lugar para o arquivamento institucional. *Ver Seção de Intervençōes.

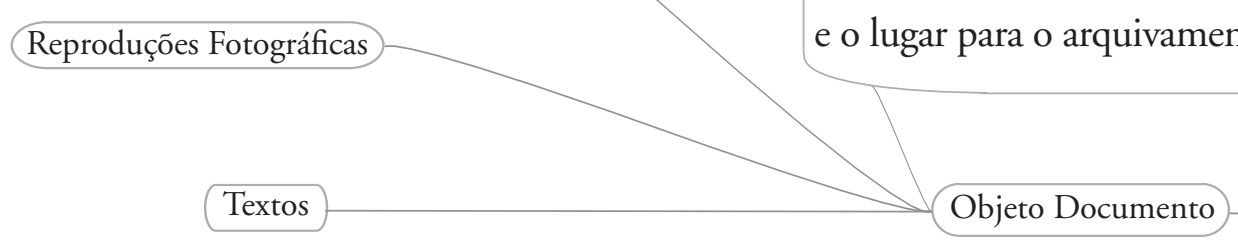

A equipe responsável pela documentação e arquivo foi convidada a pensar desdobramentos das obras propostas pelo projeto. O produto desta colaboração entre artistas e arquivistas é uma versão das obras. Assim, os procedimentos tradicionalmente utilizados para operações de arquivo passam a não mais se colocar como submetidos à criação, mas como uma etapa do processo criativo da ação artística.

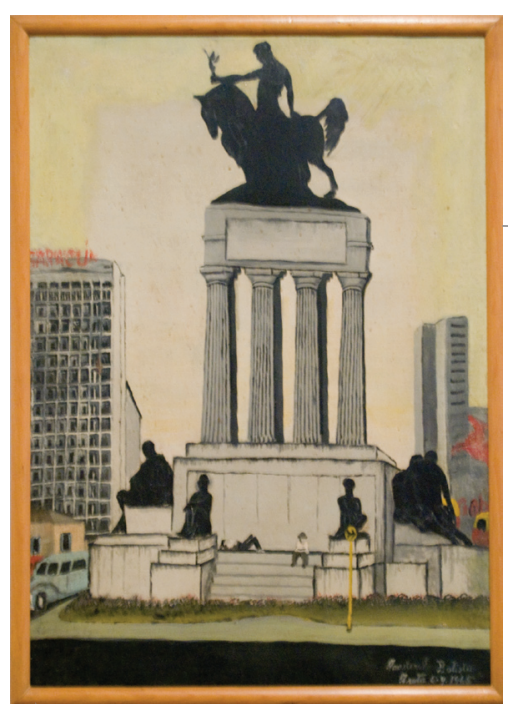

Algumas obras do acervo da Pinacoteca são removidas das exposições das quais estão participando ou dos arquivos onde estão guardadas para serem re-contextualizadas. *Ver seção de Intervenções: Mnemocine

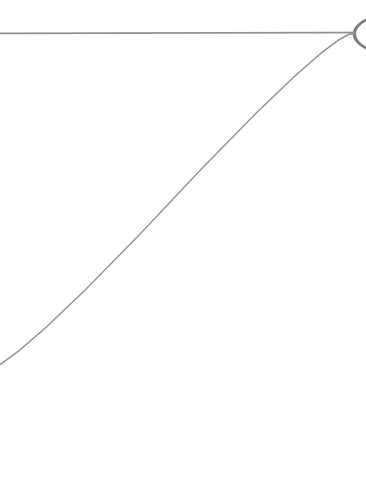

A equipe do setor curatorial foi convidada a trabalhar em desdobramentos das obras, estruturados a partir de uma discussão sobre o projeto e seus procedimentos. Os processos pensados por estes profissionais, geralmente como possibilidades de interpretação de forma anexa e posterior ao trabalho de arte, fazem parte do processo criativo, construindo possibilidades de percepção diretamente no trabalho. 


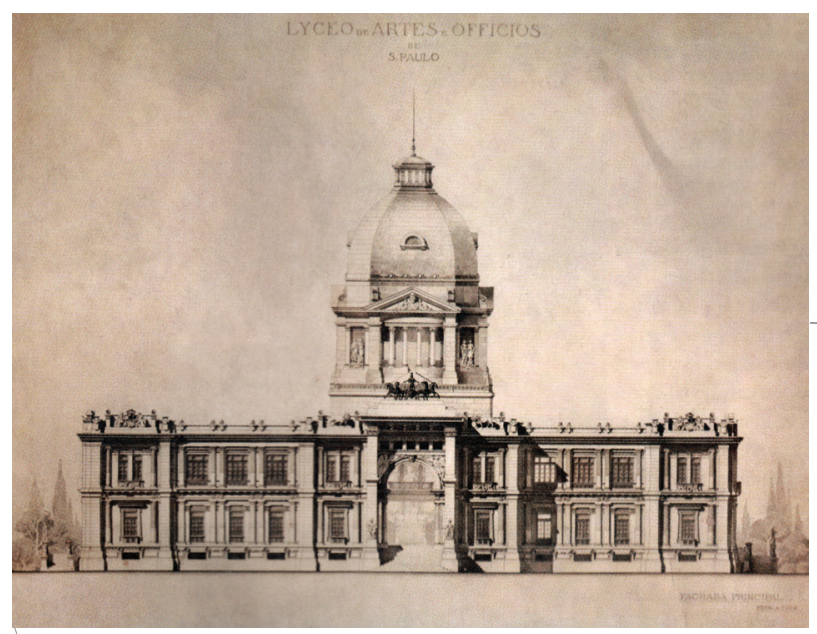

Projeto da fachada do edifício do Liceu de Artes e Ofícios realizado por Domiciano Rossi, 1897.
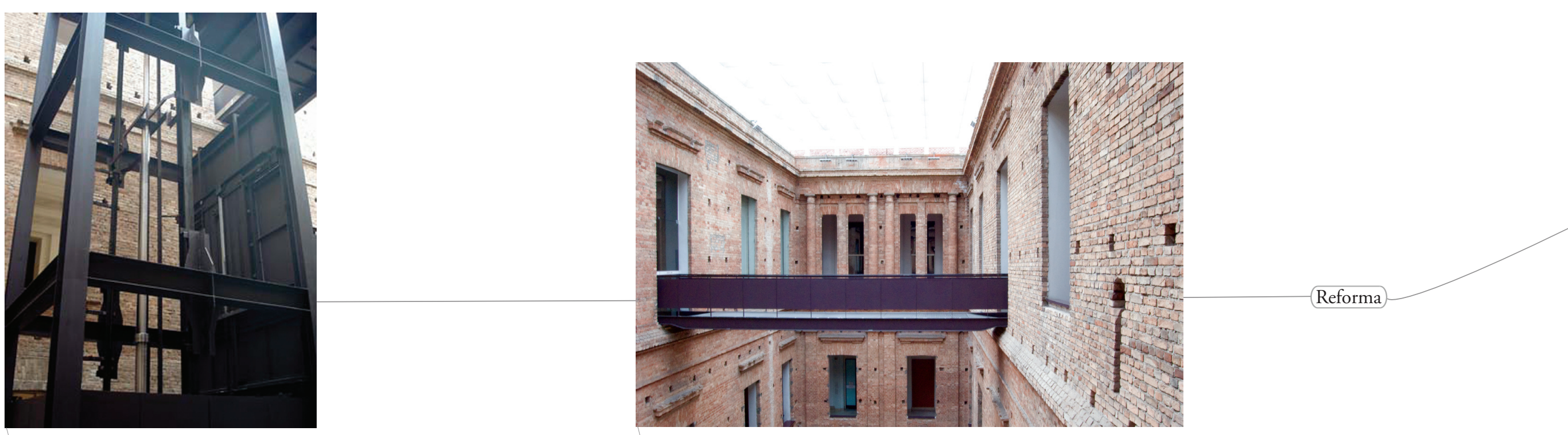

Detalhe do prédio da Pinacoteca depois da reforma geral do arquiteto

Detalhe do prédio da Pinacoteca depois da reforma geral do arquiteto Paulo Mendes da Rocha iniciada em 1994

Paulo Mendes da Rocha iniciada em 1994. 


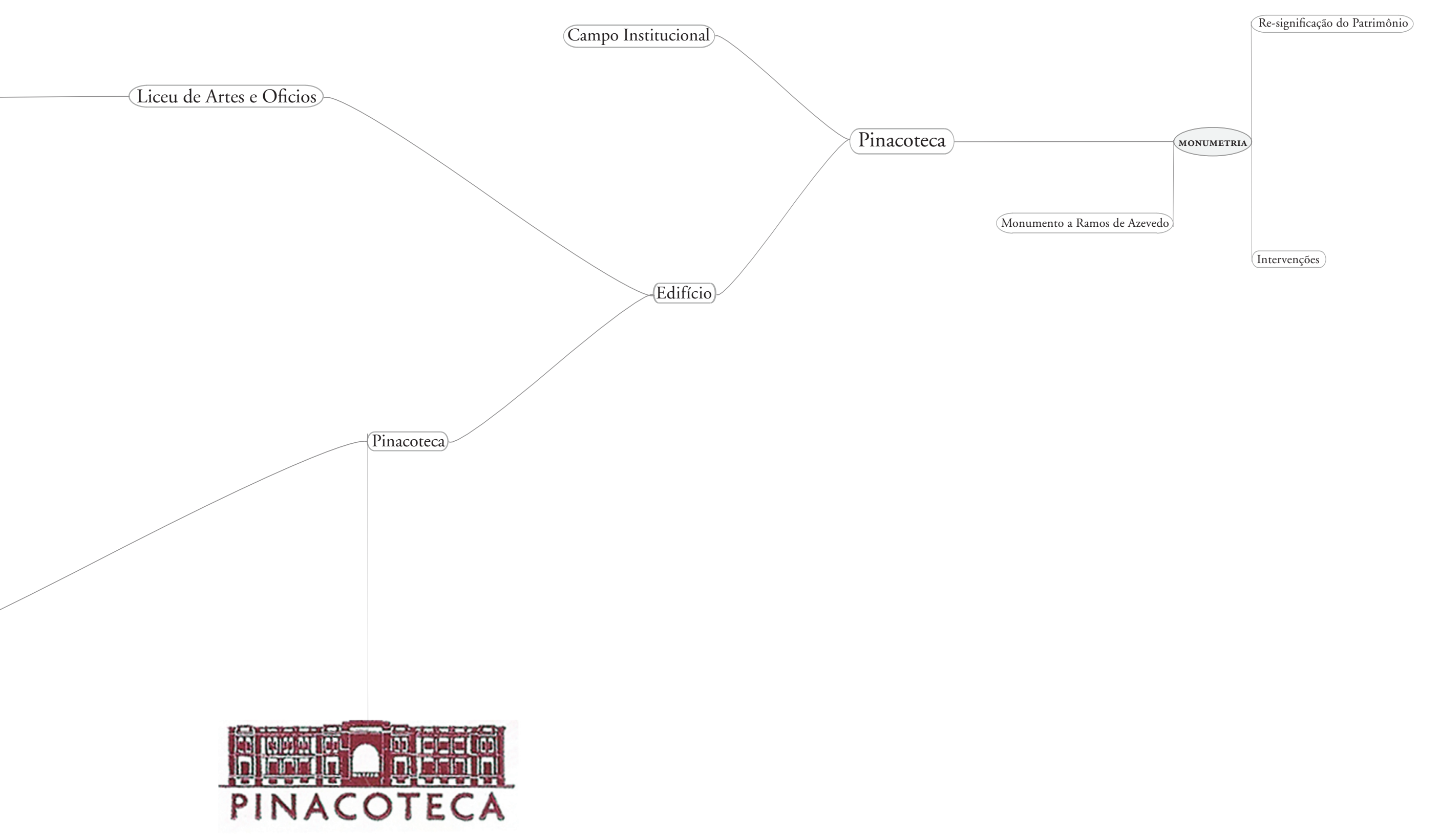




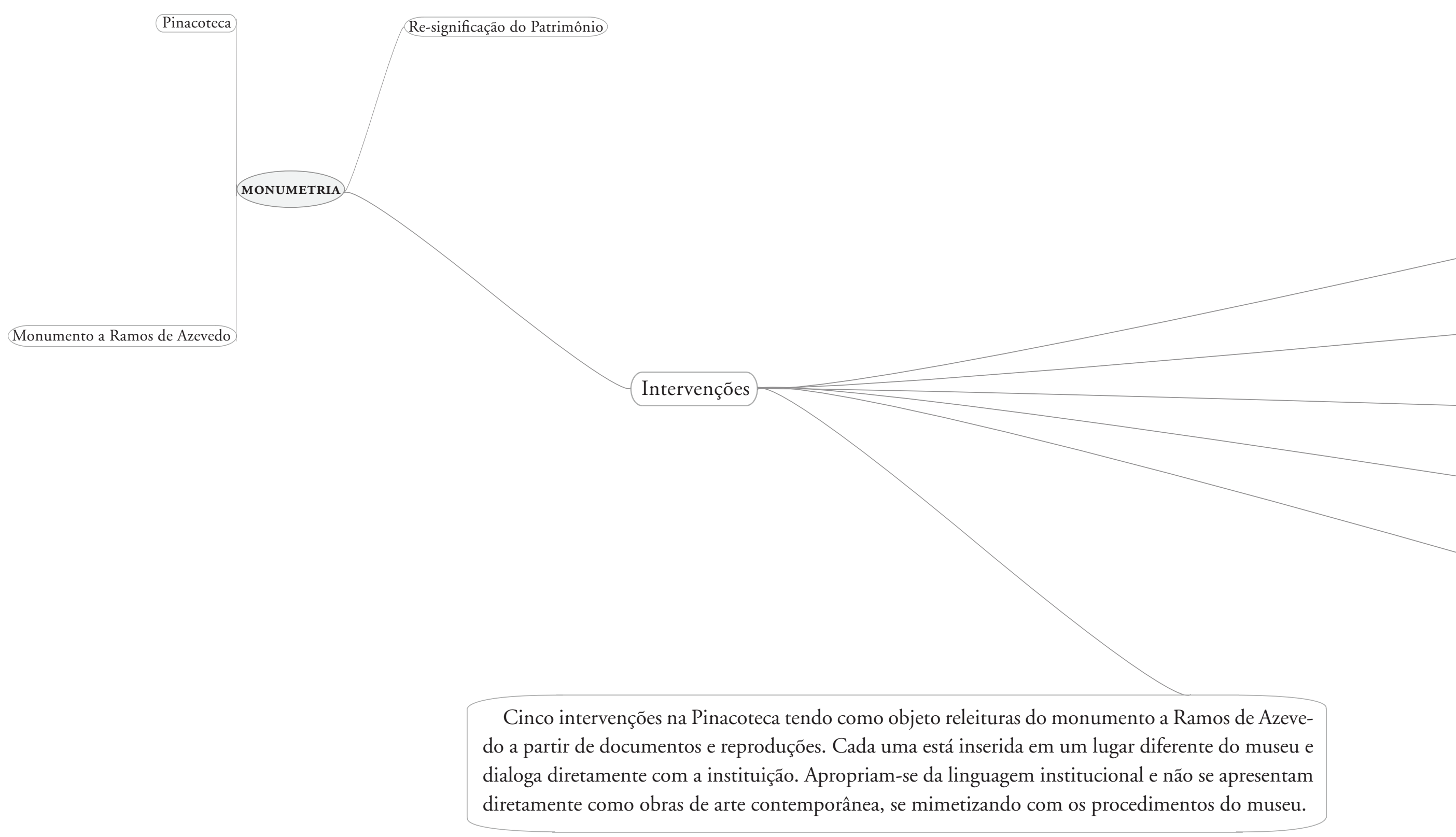


Perspectiva e Projeção

Mnemocine

Trabalho e Reprodução

Reconstituição

Publicação 


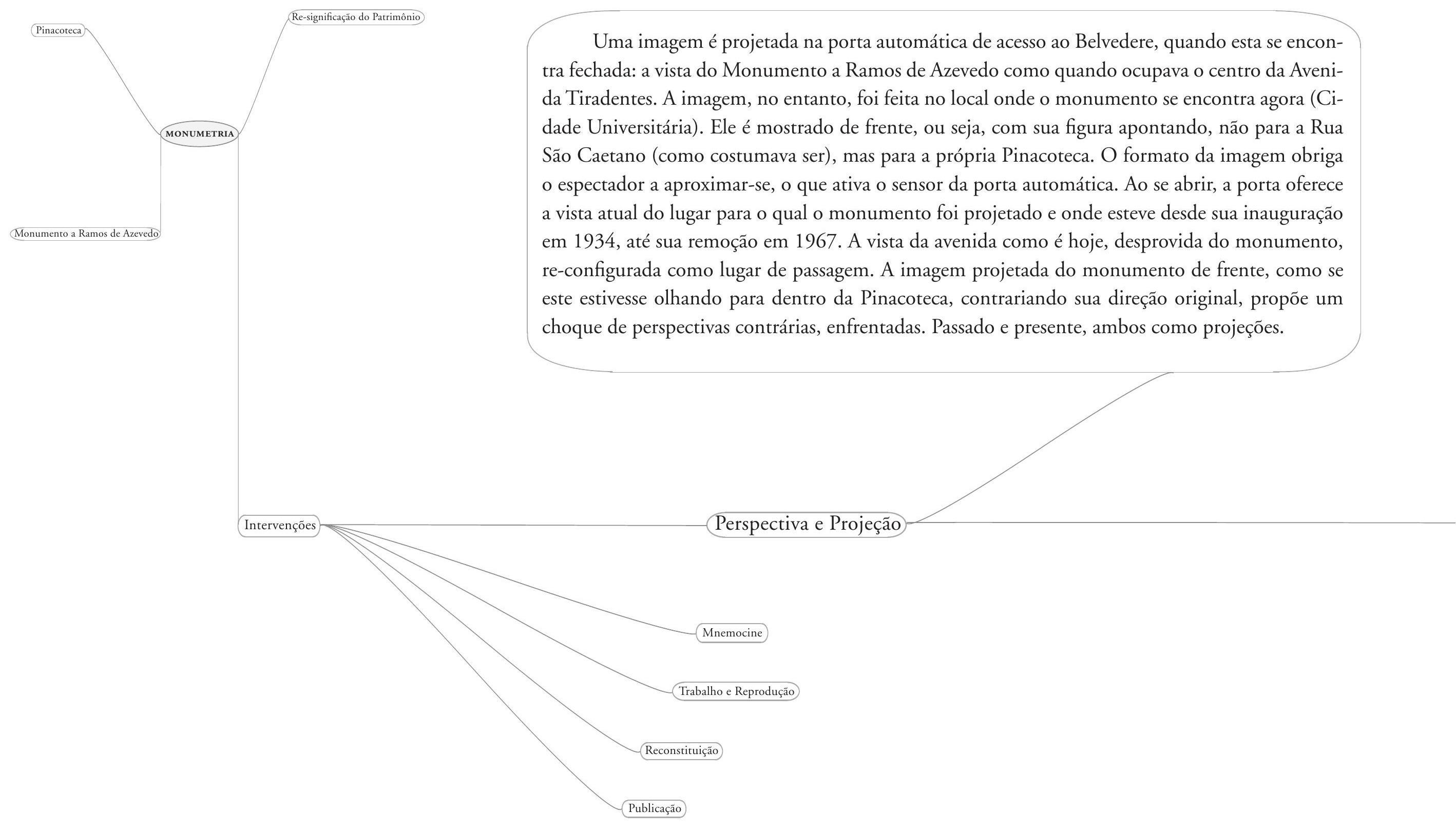




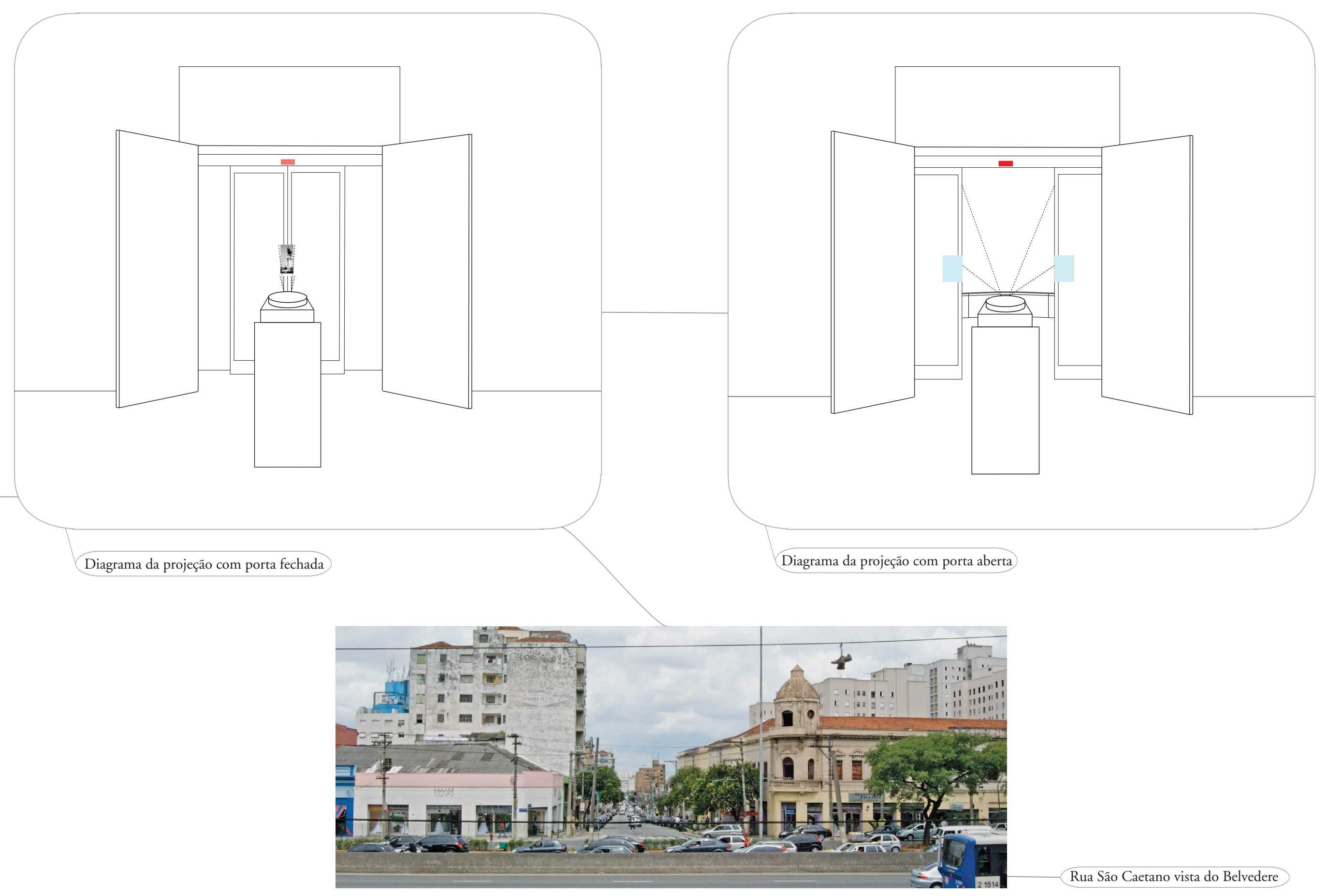




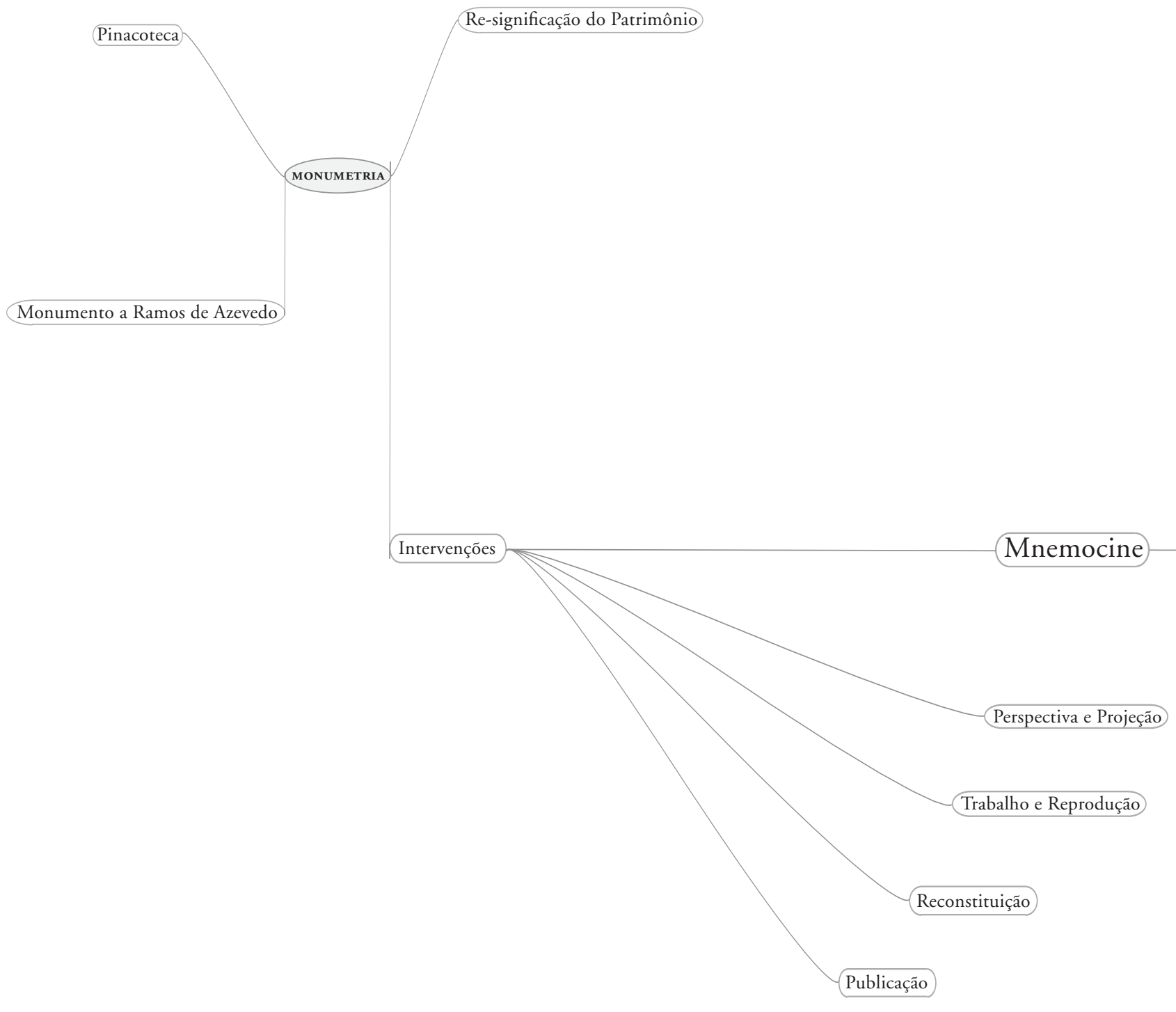


Diferentes tipos de documentos, pinturas, esculturas, fotografias de arquivo, fotografias recentes, desenhos, cartas e plantas são dispostos num painel expositivo de vinte metros de extensão por quatro metros de altura, que no conjunto resulta em uma narrativa visual.

O fio condutor desta narrativa são as fotos de um álbum pertencente aos arquivos da fundição responsável pela feitura do monumento a Ramos de Azevedo (Bronzes Artísticos Rebellato), que contém registros das etapas de sua construção e de seus fragmentos quando desmontado. Estas imagens acabam por oferecer uma nova possibilidade de leitura das figuras e narrativas alegóricas que contém o monumento. $\mathrm{O}$ que nos diz, por exemplo, a estátua de Ramos de Azevedo, fragmento do monumento, reposicionada solitariamente em espaço aberto? Ou ainda, um grupo de trabalhadores dentro do torso acéfalo do cavalo que, no conjunto do monumento, junto a outras figuras, representaria o progresso? Estas imagens, mesmo que lidas como registro de uma condição efêmera destes fragmentos, são reveladoras das contradições presentes no discurso constituinte do monumento como um todo.

Assim, ao se relacionarem, no espaço do painel, com os outros documentos (dos quais alguns fazem parte do acervo da Pinacoteca), estas fotografias podem fundar novas narrativas para a compreensão histórica. A ação editiva da intervenção propõe relações entre diferentes momentos históricos, situações, tipos de representação, qualidades de documentos, formas de exibição e materialidades. E assim, diferentes temporalidades, percursos e distâncias para sua leitura. 


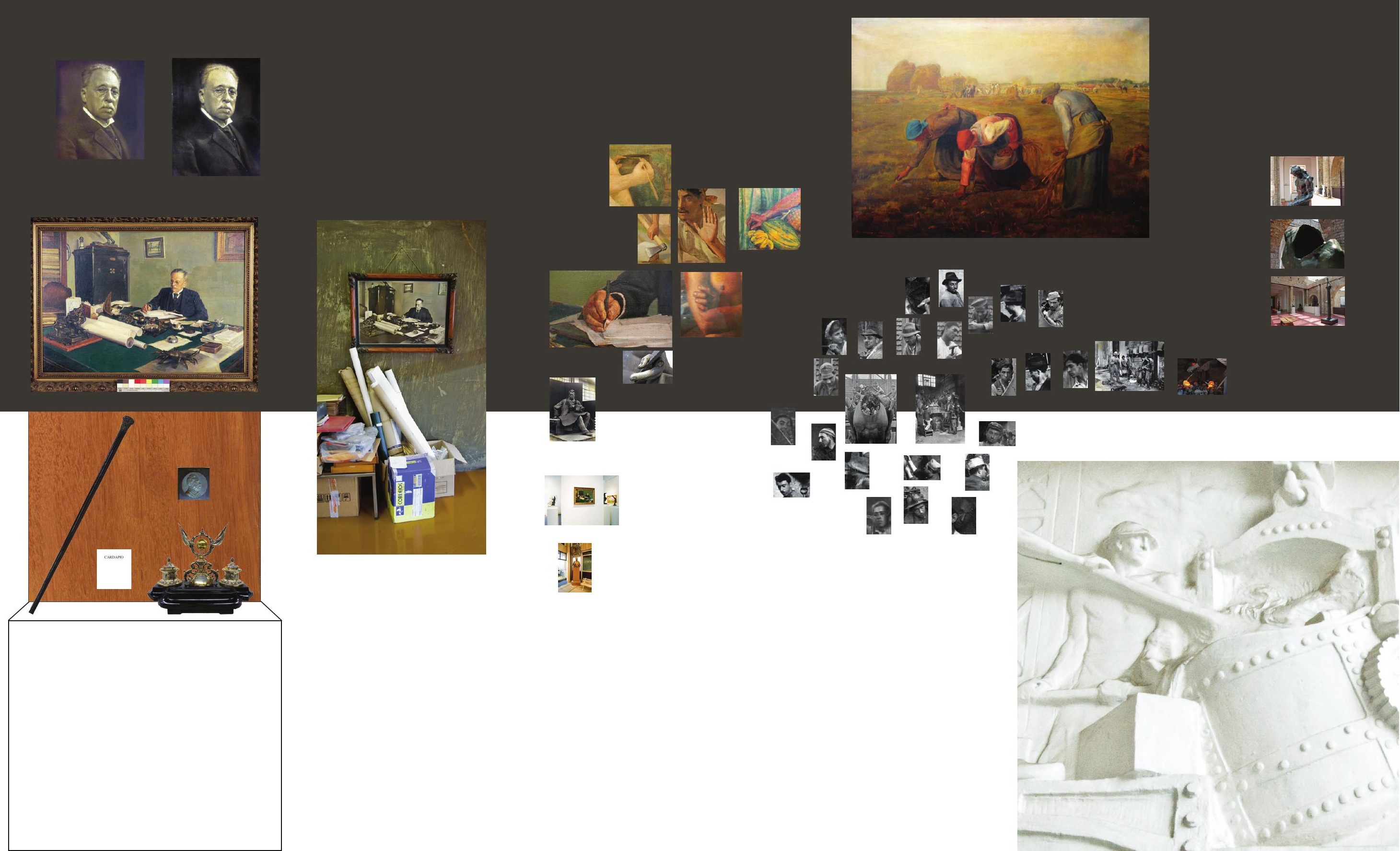




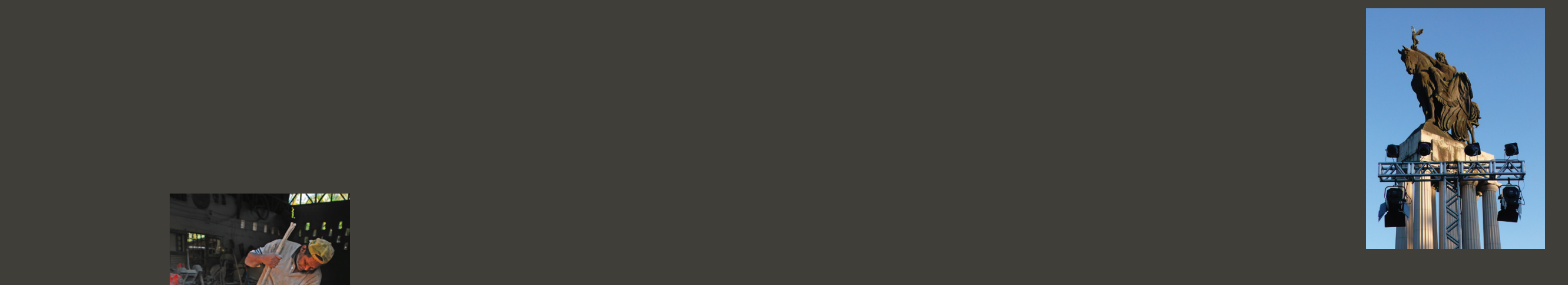

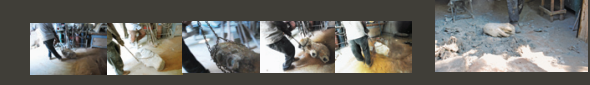

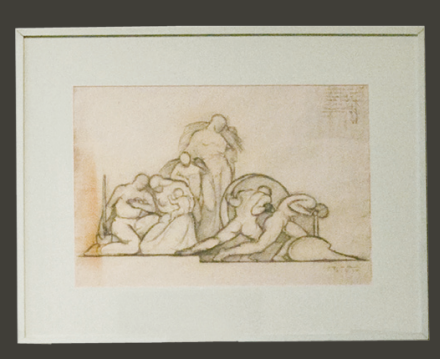

s.
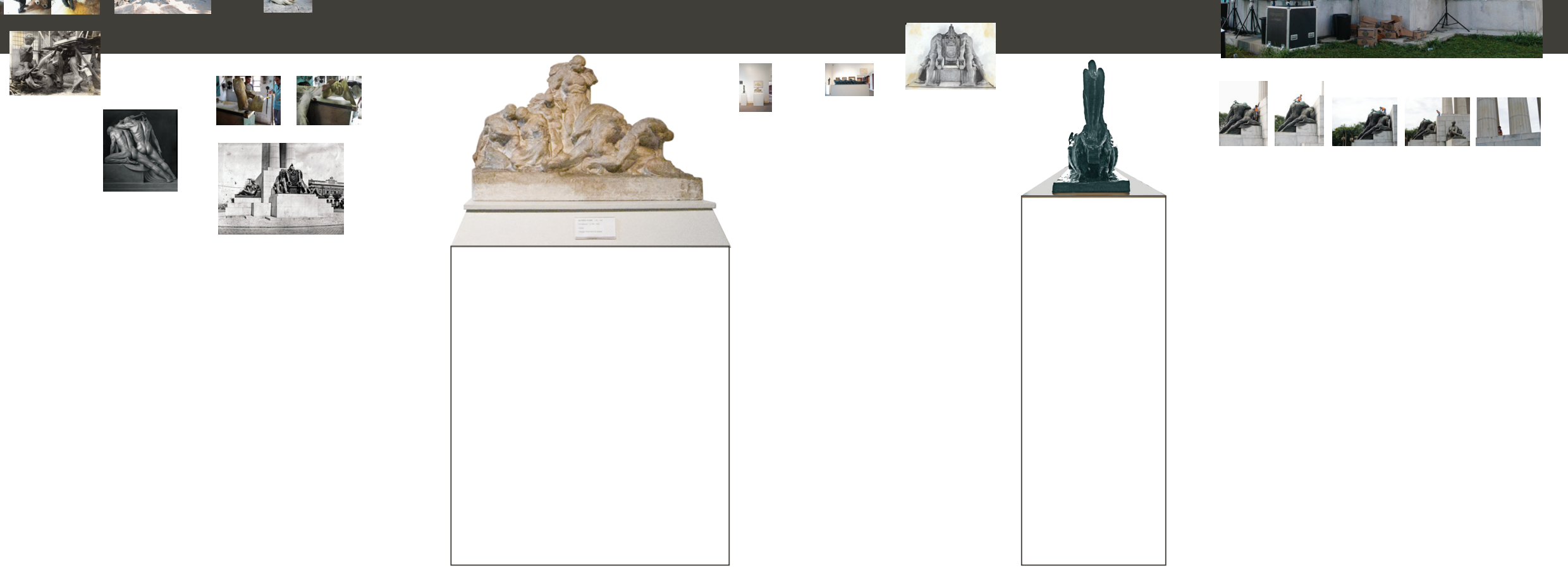

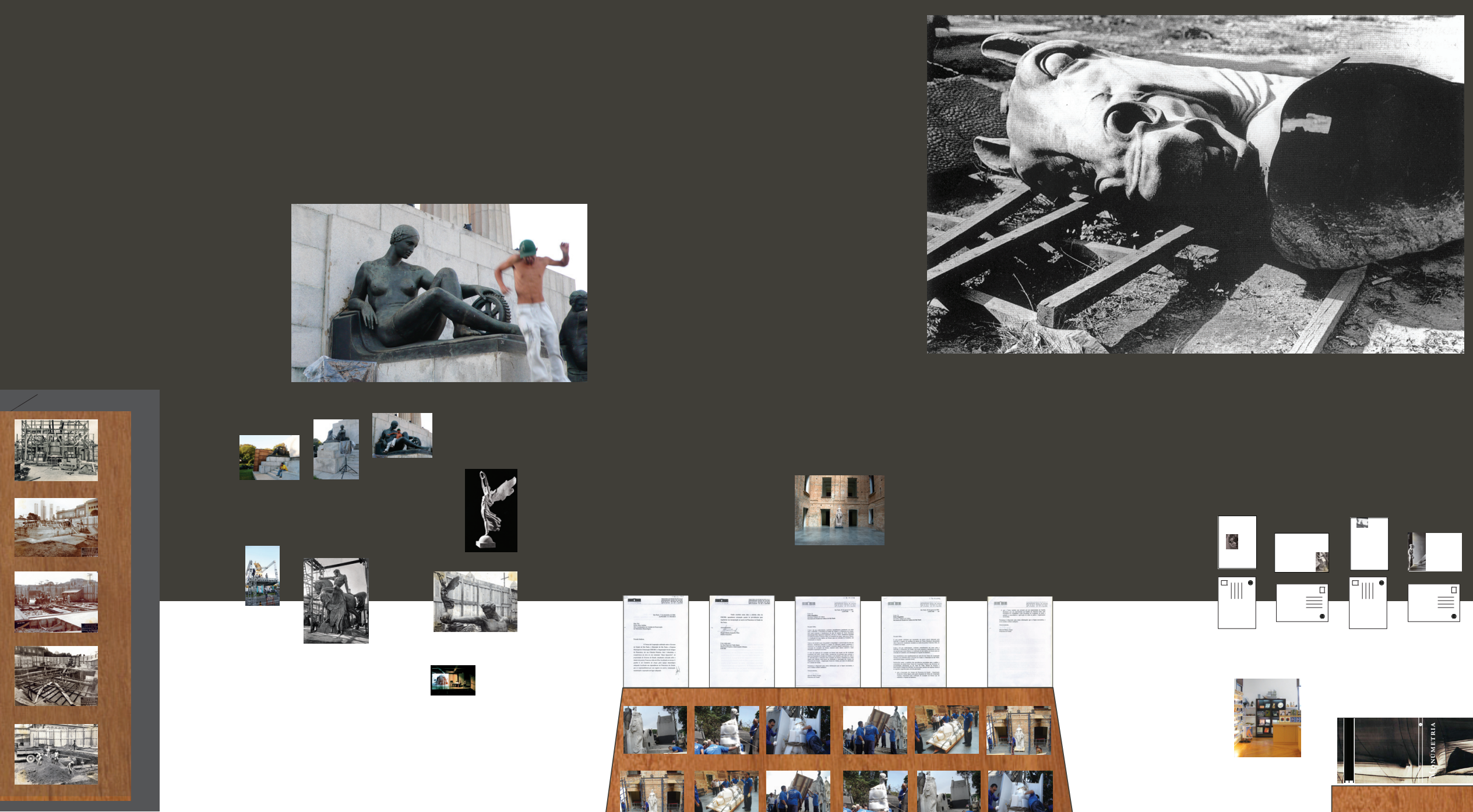

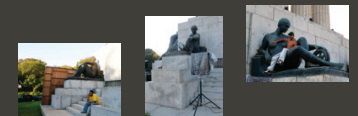

art

4 (2)

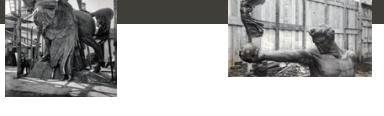

踓
(1)

PrCh was
1.

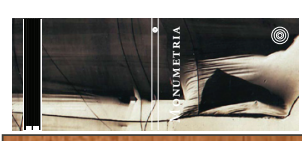




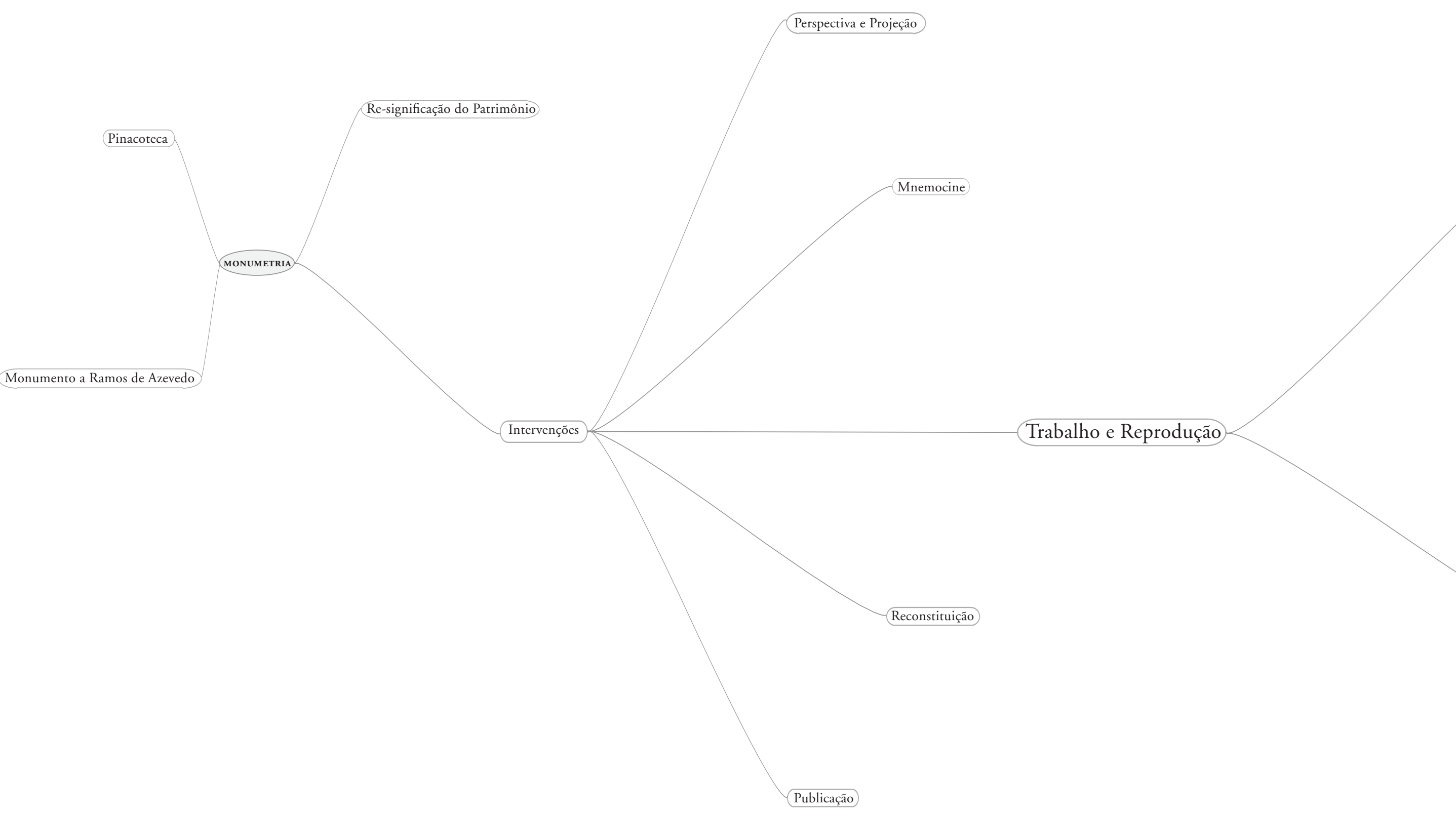


A partir de um fragmento do monumento é produzida uma seqüência de moldes, os mesmos que lhe teriam dado origem. Este fragmento é resultado de um recorte que contorna a mão com o martelo, o braço, passando pelo ombro, parte das costas, voltando pelo seio da figura feminina da 'Alegoria à Escultura'. A sequiência é apresentada na sessão de escultura francesa do século XIX da Pinacoteca, substituindo os moldes que aludem às etapas do processo de fundição. Fragmentos de um excerto de 'Sobre os Símiles' de Kafka substituem os textos didáticos usados para explicar passo a passo sua reprodução, aplicados às bases em que está disposta a sequência de moldes.

Os fragmentos do texto usados são os seguintes: 1- Muitos se queixam de que as palavras dos sábios não passam de símiles, mas não utilizáveis na vida diária - e esta é a única que temos. 2- Todos esses símiles, na realidade, querem apenas dizer que o inconcebível é inconcebível, e isso nós já sabíamos. Porém aquilo com que nos ocupamos todos os dias são outras coisas. 3- A esse respeito alguém disse: "Por que vocês se defendem? Se seguissem os símiles, teriam também se tornado símiles e com isso livres dos esforços do dia-a-dia". 4- Um outro disse: "aposto que isso também é um símile". 5- O primeiro disse: "Você ganhou". 6- O segundo disse: "Mas infelizmente só no símile". 7- O primeiro disse: "Não, na realidade; no símile você perdeu".

Do lado dos moldes está o mesmo fragmento ao qual os moldes se referem, como o resultado material desse empreendimento didático.
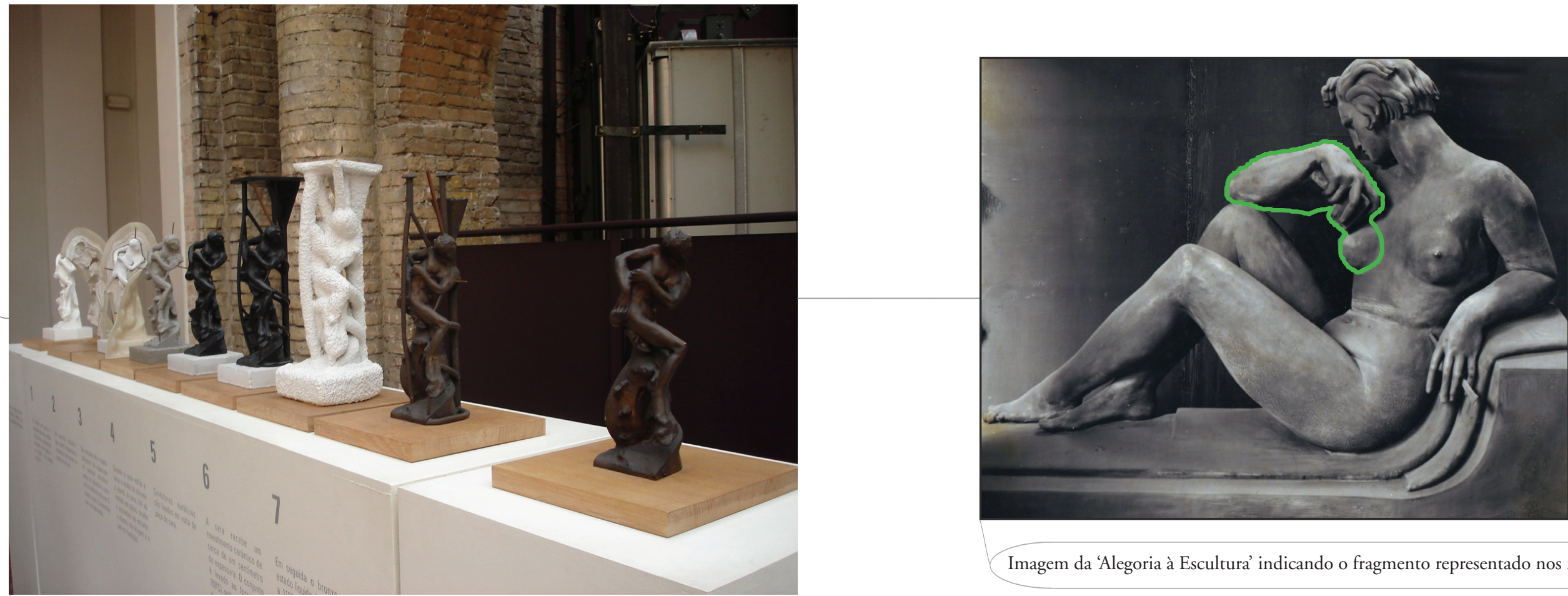

Imagem da 'Alegoria à Escultura' indicando o fragmento representado nos moldes.

Registro da seqüência de moldes de uma escultura de Rodin, na seção de escultura francesa do século XIX da Pinacoteca. 


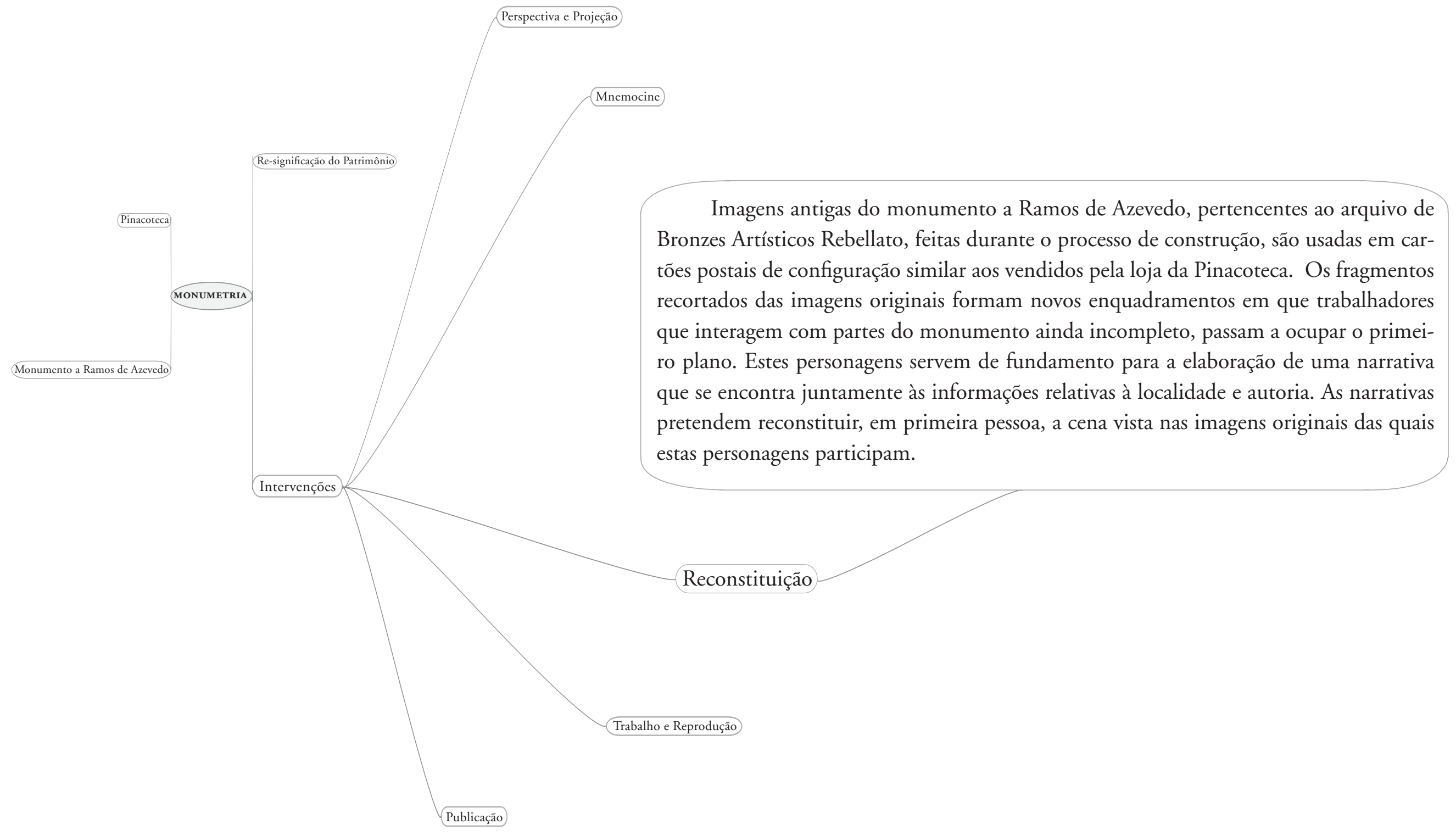


Gosto de me sentar equilibrado no braço do Gênio durante boa parte dos intervalos entre os turnos de trabalho, mas não de frente para o Progresso. Não é muito da paisagem que se levanta a esta altura. Daqui vejo tudo. Só a Vitória está acima de mim. De suas asas gosto mais do que as do cavalo, tão rígidas quanto uma armadura. Por estar incompleto, fica preso aqui comigo.

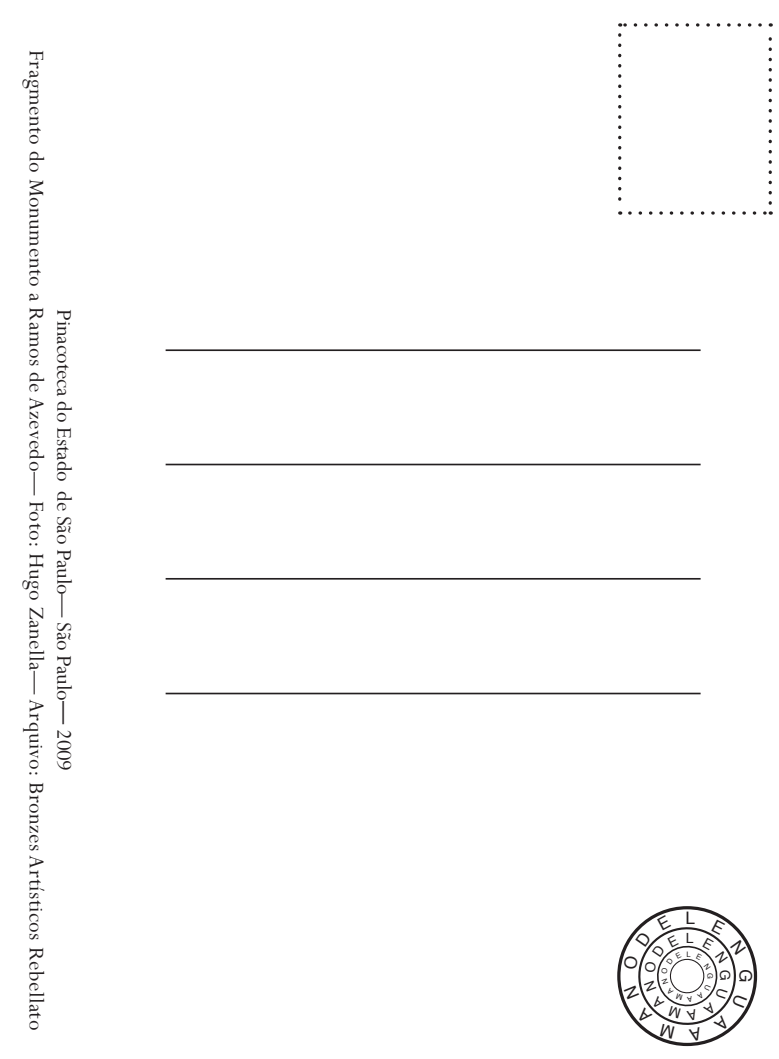




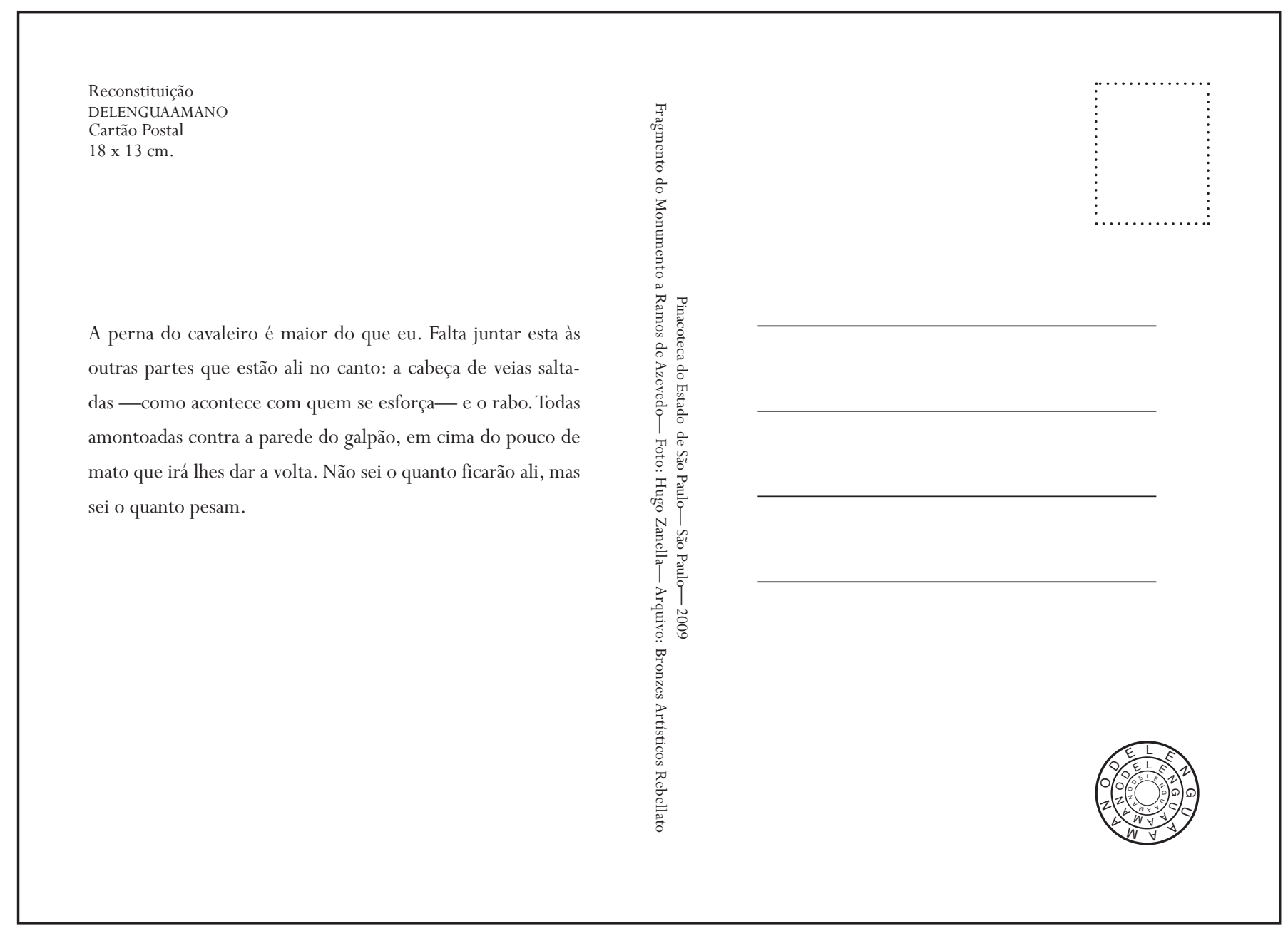




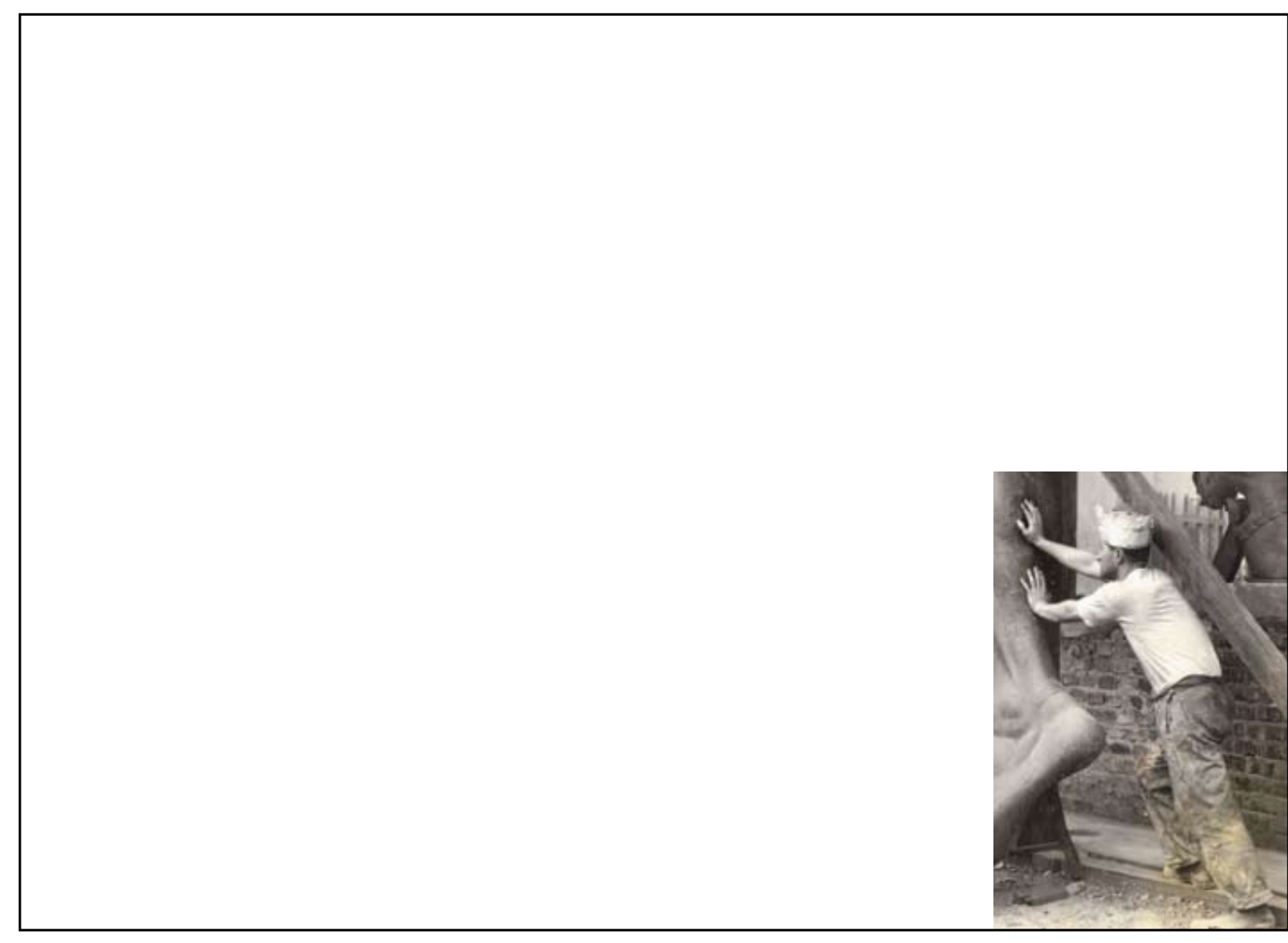




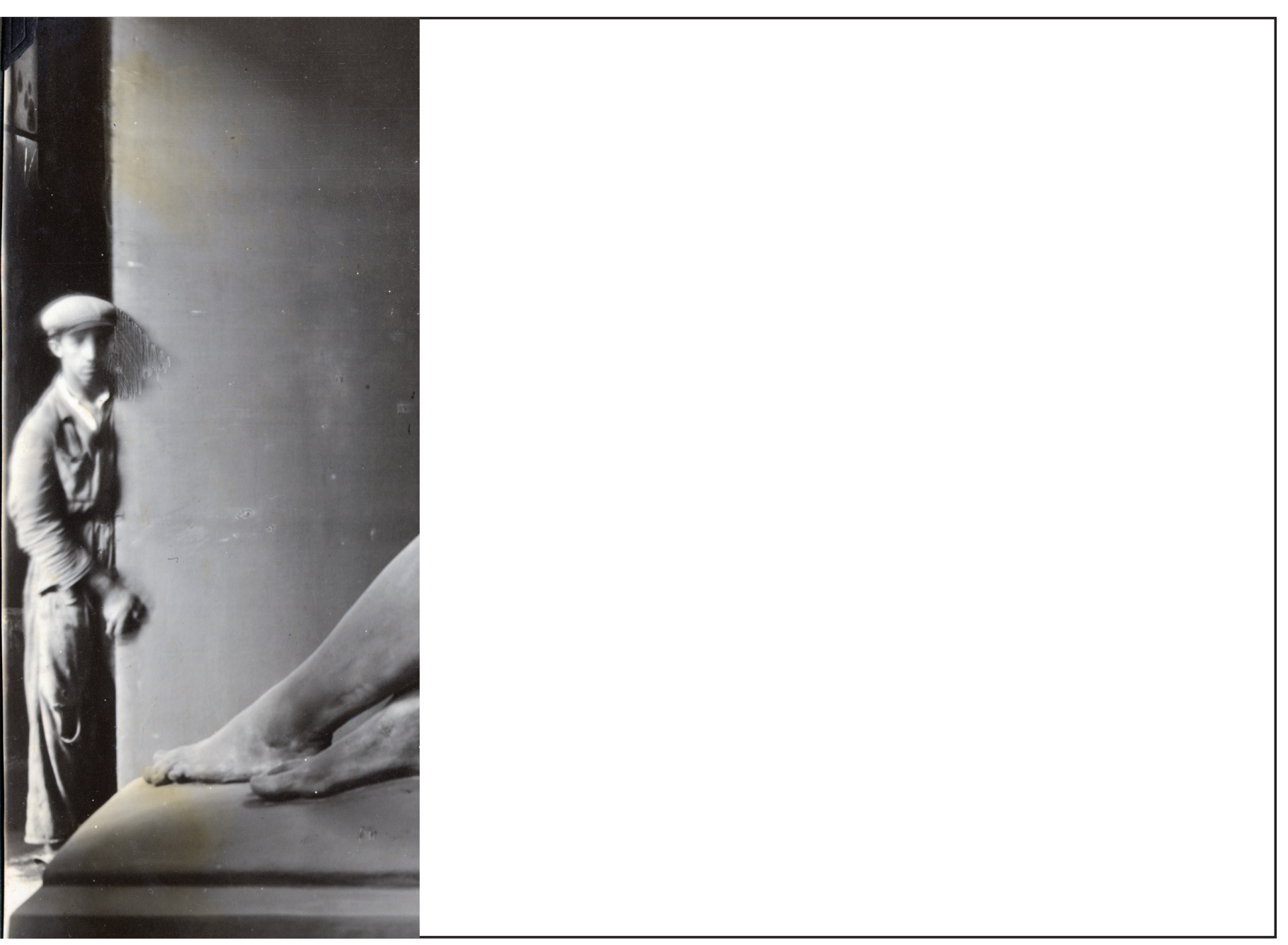




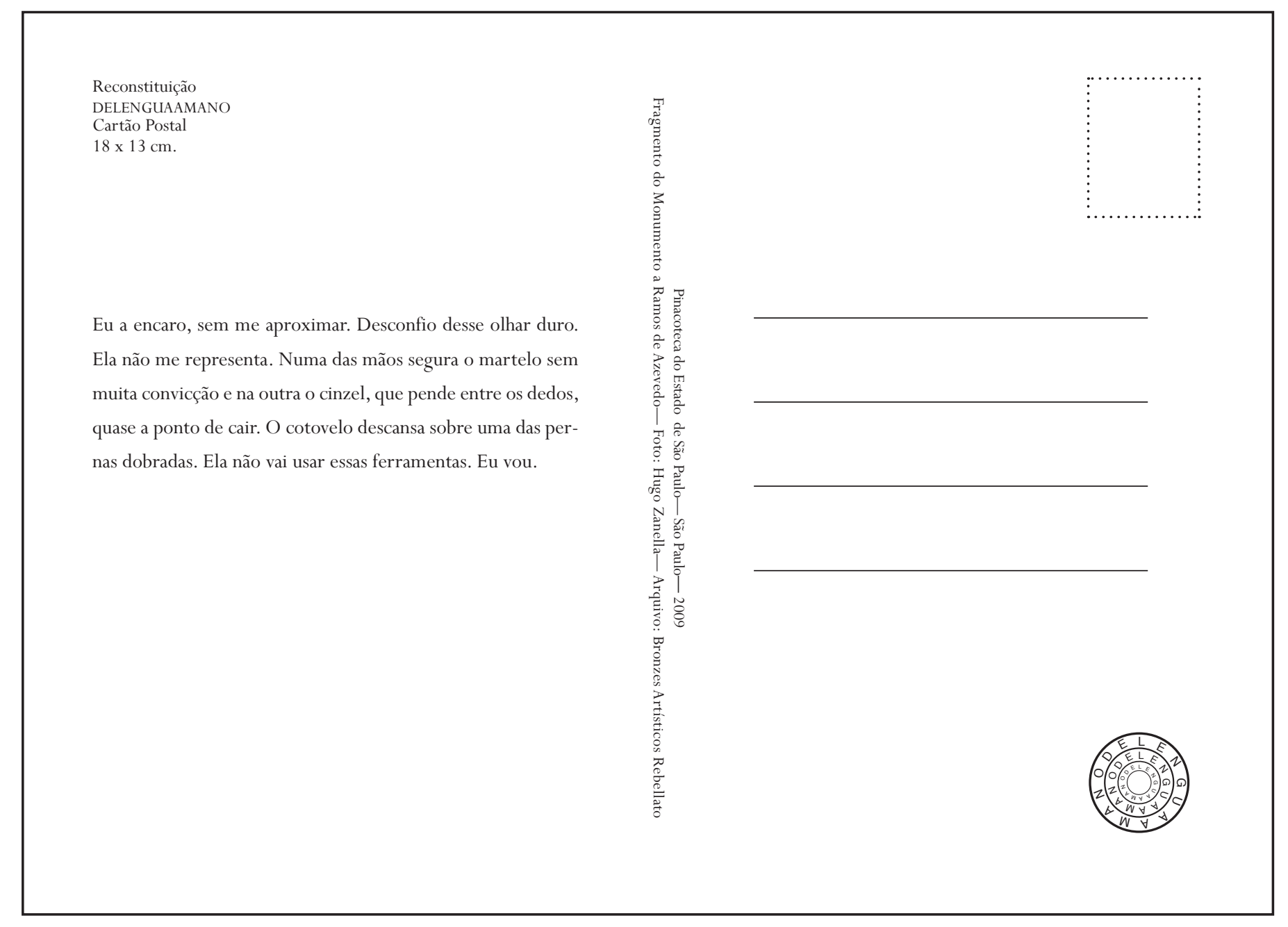




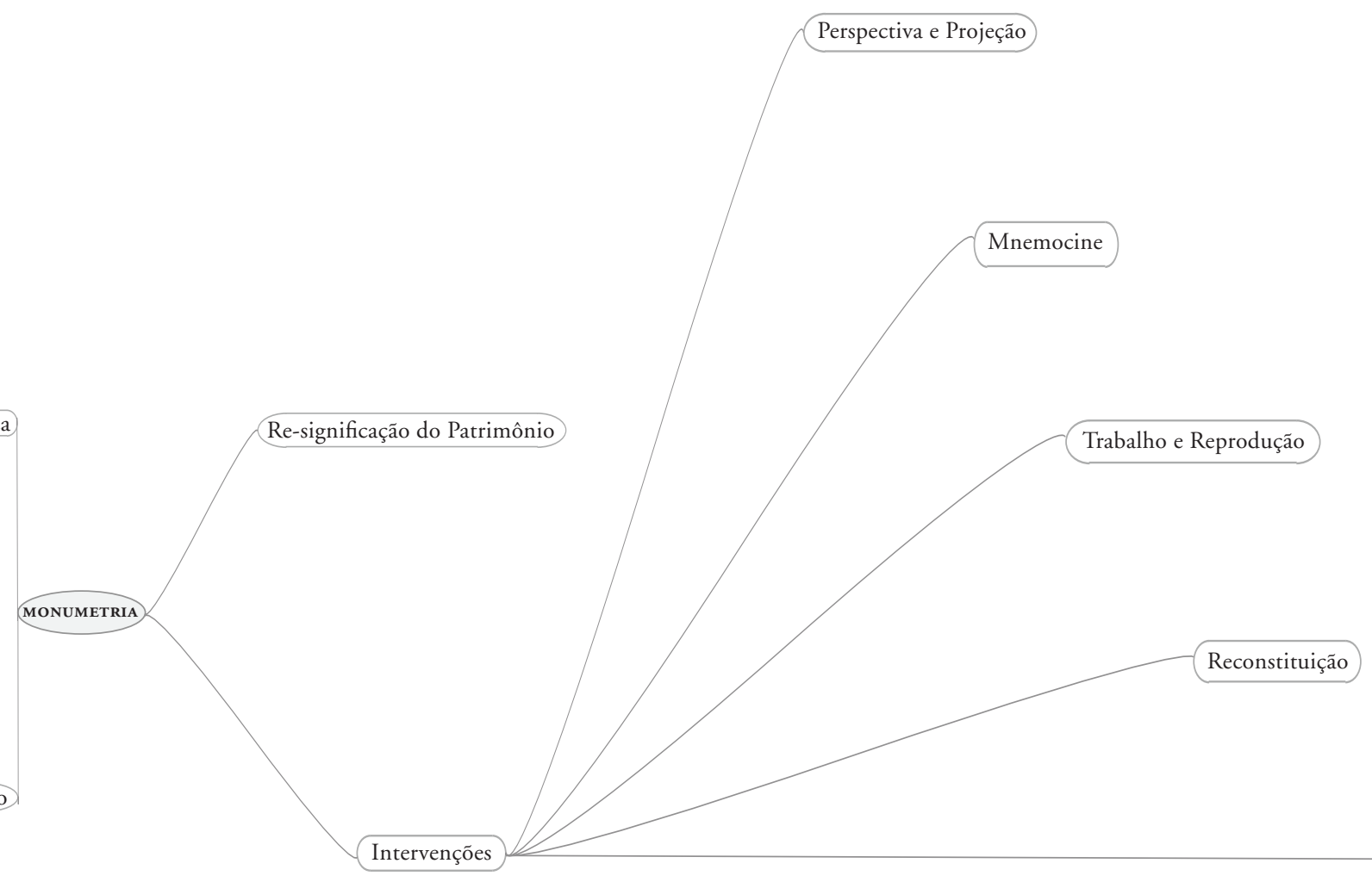


O projeto consta de uma publicação que não se propóe a ser o registro que representaria Monumetria, como memória póstuma. Antes se assume como lugar da obra. Não bastando servir como forma de transmissão e reminiscência do projeto, deve ser seu desdobramento na instância gráfica, com a especificidade de suas possibilidades materiais e expressivas. Reitera, neste outro momento do projeto, a postura que abdica de uma suposta transparência do registro e entende sua linguagem como campo transformador, dando continuidade à reflexão acerca da produção de memória e seus meios, não limitada ao tempo e espaço das intervençóes na Pinacoteca. 
Pinacoteca

Monumento a Ramos de Azevedo 
METRIA 

trabalho inacabado, trabalho compartilhado: um relato 
Referir-se à Monumetria(1) coloca duas dificuldades iniciais que influem diretamente sobre as possibilidades de se analisar o trabalho: Como discutir uma obra que ainda não foi totalmente realizada e nem exposta? E, pode meu ponto de vista abarcar o significado de um trabalho realizado em grupo e representá-lo legitimamente? Não pretendo responder essas perguntas neste texto, mas sim relatar as razões pelas quais são significativas. Começarei pela segunda.

Monumetria surgiu como gesto de apropriação que, em primeira instância, se valeu de um monumento que existe materialmente, que tem um autor, uma história e uma relação com seu entorno urbano. Apropriou-se da obra de um artista para re-significá-la a partir do território da arte em seu contexto contemporâneo. Ou seja, seu ponto de partida é outra obra de arte. Tampouco é um trabalho concebido e realizado só por mim, mas pelo grupo DELENGUAAMANO, que integro junto aos artistas Gilberto Mariotti e Santiago Reyes.(2) Seus fundamentos foram postos pela pesquisa que comecei individualmente e que está materializada neste projeto de mestrado, mas as intervençôes que compreende foram desenvolvidas em grupo, sem autorias individuais.

O deslocamento do monumento colocou perguntas sobre seu significado em seu lugar de origem, em seu contexto atual e em seus espaços de reprodução e circulação. Para dar um sentido atual ao monumento, estas reflexões deviam pensá-lo em relação a esses contextos e, também, em relação aos possíveis espaços de memória atuais, capazes de lhe dar certa ressonância. Para que o monumento fosse reativa- do, ou seja, para que gerasse sentido na atualidade, deveria ser recolocado em uma escala pública. Isso não quer dizer que pretendíamos lhe devolver seu status original - algo que considero contraproducente e na contramão de um significado do público na atualidade - mas gerar um contexto capaz de transformá-lo, colocando-o como uma pergunta relevante. $\mathrm{O}$ monumento, entendido na sua versão original, reivindica valores totêmicos e idealizados do público, incapazes de encarar seu atual caráter instável e fragmentário. Foi esse sentido de público que o deslocamento do monumento fraturou, e é essa fratura que sua memória tem capacidade de testemunhar, na medida em que o movimento mencionado é sua materialização. Nesse sentido - como monumento deslocado - é atual, coloca questões sobre os movimentos urbanos e a maneira como se constitui o espaço da cidade de São Paulo.

A primeira materialização de minhas reflexões sobre o deslocamento do monumento foi a obra 'O cavalo', uma projeção de slides que, na sua totalidade, mostra um parágrafo escrito por seu autor -Galileo Emendabili- o qual explica a simbologia de um fragmento do monumento. O texto diz:

Está visto que não se trata, aqui, do cavalo comum, fotografado do natural, e sim, como na heráldica, de uma figura estilizada, ampla, cheia de espírito, vigorosa no conjunto e imponente pela sua atitude dominante. Pus-lhe asas para significar mais claramente a sua função pura de símbolo, e também no intuito deliberado de expressar que, entre os progressos das cidades, o de São Paulo, que não pode ser desligado do nome de Ramos de Azevedo, foi mais rápido, mais dinâmico.(3) 
A projeção termina com a palavra 'dinâmico' antes da frase acabar, deixando o texto truncado e aberto. A fragmentação do texto também se dá pela disposição espacial das imagens. Cada slide mostra uma palavra e os signos de pontuação são retirados. O que se vê é a sucessão de palavras-imagens isoladas, com um ritmo constante que remete ao galopar do cavalo e estabelece o ritmo da leitura e a separação da totalidade da frase em fragmentos.

Esta obra tem a vantagem de ser versátil. Permite sua apresentação em diversos contextos sem perder especificidade. Cheguei a mostrá-la em apresentações e como apresentação, em geral dentro de um marco acadêmico. A obra consegue colocar questóes sobre o deslocamento e sobre a representação da memória do monumento posta em circulação, mas sua dimensão pública é tímida. Essa foi a impressão que tive. Percebi que me interessava alcançar uma dimensão na qual o monumento estivesse em condiçôes de gerar conflito e abrir discussões mais amplas sobre a cidade.

No final de 2007 fiz uma visita à Pinacoteca do Estado de São Paulo com meus colegas de grupo Gilberto Mariotti e Santiago Reyes, na qual discutimos a problemática aberta pelo deslocamento do monumento. Na discussão surgiram algumas idéias de obras que colocavam a questão a partir do espaço da Pinacoteca. Pareceu-nos que esta instituição era um bom lugar para conferir a escala apropriada à problemática. Foi dessa maneira que Monumetria surgiu, buscando uma nova escala pública ao monumento que fosse capaz de re-significá-lo e abrindo meus questionamentos aos de meus colegas. Surgiu no momento em que os questionamentos colocados por minha pesquisa exi- giram se relacionar com um lugar específico da cidade e serem abertos erente. $\mathrm{O}$ próprio trabalho foi articulando a forma de sua produção.

A Pinacoteca era o lugar indicado para ativá-lo enquanto memória e lhe conferir visibilidade. Como espaço de memória, esta instituição tem a capacidade de se relacionar com o monumento por duas vias significativas: a história compartilhada entre ambos e o fato da Pinacoteca ser um espaço dedicado à reflexão sobre a arte. A Pinacoteca poderia dar a ressonância que buscávamos ao deslocamento do monumento.

Neste ponto do meu relato já poderão ser vislumbrados dois dados sobre Monumetria que se referem a uma autoria difusa. Por um lado, a apropriação de uma obra do artista Galileo Emendabili e por outro, uma série de intervençôes desenvolvidas em grupo.

A apropriação do monumento pode ser entendida como um impulso por revisitar uma história culturalmente significativa, encaminhada à desaparição e condenada ao esquecimento. De novo, não porque o monumento em si seja culturalmente relevante na atualidade, senão pela história do seu movimento. Nesse sentido Monumetria pretende funcionar no intervalo entre uma origem condenada à obsolescência e um presente que lembra para refletir sobre seu futuro.

O projeto se propôs interpretar o monumento a Ramos de Azevedo através de seus rastros, ou seja, os registros capazes de se relacionar com sua história. Para isso optamos pelo uso de documentos de diferente natureza e procedência. Criaram-se as condiçôes para uma espécie de 'arquivo exposto' de relações em potência, que pudesse dar 
as pautas para re-significar uma história e atualizá-la. Em nenhum momento se pretendeu fornecer uma imagem completa nem estável dessa história, pelo contrário, aproveitar-se das brechas entre alguns de seus fragmentos significativos, relacionando-os entre si, e dessa maneira abrindo diferentes narrativas em potência.

Na medida em que a história é um processo re-elaborável, que se escreve descontinuamente a partir de rastros, as operações da memória se entendem como processos abertos e flexíveis de inscrição que produzem registros. Estes registros não são permanentes e seu significado depende de como se relacionam com outros registros, se são expostos ou não, postos em circulação ou não, etc. Com o tempo vão se redefinindo, acumulando informação nova, relegando informação em desuso e assim adquirindo novos significados, como as lousas apagáveis das crianças que Freud usou para exemplificar os processos psíquicos de inscrição da memória(4), ou como um palimpsesto.

Se Monumetria incorpora a apropriação como um dos seus modos fundamentais de operação, esta não deve ser entendida exclusivamente em termos do monumento, mas de um repertório amplo de registros, que não estão necessariamente ligados com este, nem entre si de forma direta. Existe uma descontinuidade evidente entre alguns destes registros, e sua função nas intervenções tem um caráter fragmentário, que tende a se distanciar de representações estáveis. Como que tentando imaginar a ruptura do monumento com certa tradição e certa história, no limite do deslocamento entre um objeto cultural e sua representação.
Como se dão as apropriações? Em cada intervenção acontecem de maneira diferente. Em 'Perspectiva e projeção'(5) usamos um slide com a imagem do monumento em seu lugar atual, retirada de um livro. Apropriamos-nos dessa imagem e a apresentamos como documento.

'Reconstituição'(6) se vale da forma cartão postal, tendo aqueles vendidos na loja da Pinacoteca como ponto de referência e usando o mesmo formato e a mesma informação: nome da obra, autor, data, etc. As imagens usadas são fotos de registro de Hugo Zanella que mostram cenas de trabalho envolvendo fragmentos do monumento. As fotos originais já apresentavam a imagem do monumento fragmentado, e nos postais, estes registros são fragmentados de novo. Só se pode ver uma pequena fração da cena total, onde aparece sempre um trabalhador. A imagem mantém a proporção da foto e a relação do fragmento a vista com a totalidade da imagem original. $\mathrm{O}$ espaço restante fica em branco. $\mathrm{Na}$ parte de trás há uma narração em primeira pessoa, do personagem da foto sobre o que acontece na imagem. Esta narração subjetiva completaria textualmente a cena fragmentada, abrindo-a à imaginação do narrador e do leitor. As ações de narrar e de ler transformam a imagem original, mudam seu conteúdo e seu significado.

'Trabalho e reprodução'(7) se apropria de um fragmento do monumento e o apresenta como explicação didática do processo de trabalho. Também se apropria de um texto de Kafka e o relaciona com o que acontece na seqüência de moldes. No final, a promessa de explicação não se cumpre e o que parece um simulacro pedagógico se mistura com as esculturas 'acabadas' expostas no lugar (Seção de es- 
cultura Francesa do século XIX). O anexo pedagógico como realidade materializada.

No caso de 'Mnemocine'(8) a apropriação é mais profusa. São usadas obras de arte do Acervo da Pinacoteca, e outros objetos de memória também da coleção, como documentos escritos que fazem parte dos tramites institucionais que representam os movimentos na Pinacoteca, registros de obras do museu em exposiçãa, registros do espaço da Pinacoteca e seu entorno, uma planta arquitetônica, o projeto que ficou em quarto lugar no concurso para construir o monumento, fotografias de registro da construção do monumento, de sua inauguração, da sua desmontagem, de sua remontagem, do monumento no seu lugar atual e do monumento como aparece nas intervençôes de Monumentria.

Os limites da autoria são uma questão que tem acompanhado Monumetria durante todo o processo. Quando o projeto foi proposto para a Pinacoteca, se abriram espaços de colaboração entre Delenguaamano e profissionais de diversas áreas da instituição, com o propósito de que estes interviessem em nossas propostas iniciais, partindo de suas respectivas áreas de trabalho e de interesse. Com o tempo, as colaboraçôes que se desenvolveram foram com a área de Curadoria e a área de Documentação e Memória. Começaram como discussōes sobre a especificidade dos processos desenvolvidos nas respectivas áreas de trabalho e sua relação com a construção da memória coletiva a partir da instituição. Interessava discutir como e até que ponto suas leituras das obras - que de maneira geral costumam ser interpretadas como anexos posteriores e secundários - tinham uma capacidade transformadora e uma influência sobre seu significado. Como essas leituras davam forma às obras às quais se referiam.

Ambas colaborações terminaram se materializando como desdobramentos de Mnemocine e da publicação(9). A colaboração com a área de curadoria se fez com Ana Paula Nascimento, curadora encarregada da exposição. Ela teve a iniciativa de propor algumas obras e outros objetos que fazem parte da coleção da Pinacoteca, para serem exibidos em 'Mnemocine', ampliando e abrindo as relações já existentes dentro do painel expositivo. Indicou-nos um tinteiro e uma bengala pertencentes a Ramos de Azevedo, o cardápio de um jantar oferecido no seu nome para comemorar seus 60 anos, três retratos de Ramos, dos quais dois são fotos e um foto-pintura, e um quadro de Anita Malfatti, que é uma cópia da pintura original 'Les Gleneuses' de Jean-François Millet. Esta última foi colocada no núcleo do trabalho, que relaciona diversas imagens de operários em ação. As primeiras constituem o núcleo de representação de Ramos de Azevedo e seu círculo social.

Outro aporte de Ana Paula incorporado em 'Mnemocine' foi de usar uma indicação que apontasse a re-localização das obras expostas no painel. De tal forma que o lugar da exposição permanente de onde cada obra fosse removida para ser levada a 'Mnemocine', ficasse vazio e com uma ficha indicando as razões de sua ausência.

A colaboração com o CEDOC (Centro de Documentação e Memória)(10) se fez diretamente com o diretor da área, Gabriel Moore. Com Gabriel, as discussões se centraram nas ligações entre obra, arquivo, registro e documento, de como trocam papéis entre si e incidem 
sobre a leitura dos outros. O lugar da materialização desta colaboração também foi 'Mnemocine'.

Gabriel relacionou o deslocamento do monumento a Ramos de Azevedo à transferência de 'Musa Impassível', de Victor Brecheret, do Cemitério de Araçá à Pinacoteca. A colaboração se materializou como um núcleo composto da correspondência escrita (cartas) mantida entre os atores da transferência e fotos de registro representando o movimento da obra de um lugar para o outro. Este núcleo está localizado em uma parte de 'Mnemocine' que se ocupa do monumento enquanto circulação, seja esta representada em nossos cartóes postais - 'Reconstituição' - ou nos registros da desmontagem de seu lugar original.

Outro desdobramento desta colaboração se deu no corpo da publicação. Nela aparecem as definições de Gabriel de arquivo, registro e documento com sua respectiva representação visual e suas respostas às perguntas que Delenguaamano lhe fez sobre possíveis interligaçōes entre obra, arquivo, registro e documento.

Outra influência sobre nossa proposta inicial, que definitivamente incidiu em uma das obras e é um bom exemplo da questão dos limites da autoria colocada durante o processo de trabalho pelo projeto mesmo, foi o ponto de vista de Fiammetta Emendabili (filha de Galileo Emendabili, autor do monumento a Ramos de Azevedo). Os direitos autorais que ela exerce sobre a obra do pai - e que the permitem se apresentar como sua 'curadora' - influíram diretamente sobre 'Trabalho e reprodução'. Qualquer reprodução do monumento, mesmo sendo fragmentaria, depende de sua autorização.
A idéia inicial era desenvolver a seqüência dos moldes que teriam dado forma a um fragmento do monumento e apresentá-los como anexo educativo explicando o processo de trabalho da técnica de fundição. O fragmento que havíamos escolhido é um onde confluem dois materiais diferentes - bronze e granito. É um pedaço que, de ser separado da totalidade do monumento, resulta pouco reconhecível. Junta no mesmo molde parte do pé de um dos construtores com a borda de outra peça e parte da base de granito. $\mathrm{O}$ fragmento individualizado é difuso e se afasta da representação figurativa.

Fiammetta não concordou. Não fazia sentido para ela um fragmento que não pudesse ser inteligível e lido como figura autônoma e auto-referencial. Por causa do orçamento do projeto e pelo tamanho das peças do monumento, ela nos propôs fazer a 'Vitória' em sua totalidade, porque é a figura individual menor do monumento. Achamos que essa peça não funcionaria de acordo, de modo que negociamos um ponto intermédio. Concordamos que o braço da alegoria à escultura, desde o ombro, baixando pelo torso até o final de um dos seios seria a melhor opção. Sua mão agarra um martelo que simboliza a escultura.

À Fiammetta interessava que uma obra de seu pai entrasse para a coleção da Pinacoteca, e esta deveria ser pelo menos reconhecível como representação figurativa. Para nós era indispensável que a seqüência de moldes tivesse um caráter fragmentário e que materialmente transformasse a imagem do monumento original. O braço escolhido ainda permitia a leitura fragmentaria que buscávamos mas acabava sendo uma figura reconhecível. Tivemos que assumir a figuração do fragmento e nos relacionarmos com sua capacidade simbólica de significar. 
Em termos simbólicos, o que nos interessou no fragmento foi a capacidade auto-referencial do martelo com respeito ao processo de trabalho que permitiria sua realização (sequiencia de moldes para a fundiçãa). Simboliza o processo que a explicaria colocando a ação educativa da instituição como um empreendimento material, com resultados materiais que se referem e são referidos pela obra. Decidimos trocar os textos explicativos usados pela instituição por fragmentos de um texto de Kafka sobre os símiles, nos apropriando do espaço 'cenográfico' e 'anexo' usado pela museologia, como lugar de representação capaz de transformar a obra.

Esta situação deixou claro algo óbvio, que confirma a condição de "realidade" do monumento. Por trás dele existem diferentes interesses que entram em conflito entre si e que põe em jogo problemáticas extra-artísticas de representação. É um assunto que concerne à cidade, à instituição e a alguns interesses particulares que pretendem apropriar-se do monumento e dar-lhe a representação que consideram mais apropriada ou beneficiária. Seu uso e representação estão estruturados pelos moldes da lei que definem sua imagem. Qualquer tentativa de apropriação do monumento que pretenda colocá-lo em escala pública deve enfrentar as restrições, brechas e, em resumo, as possibilidades de jogo colocadas por estes moldes. O que estaria em jogo em cada partida seria a legitimidade do processo de reprodução que definem nossa aprendizagem e lhe dão uma dimensão temporal como memória.

\section{2}

Até o momento em que escrevo este capítulo, as intervenções não haviam sido realizadas em sua totalidade. Existem como projeto, como produção em processo e agora como relato. Serão expostas junto com uma publicação, que também é assumida como intervenção, a partir de 7 de março de 2009 na Pinacoteca do Estado de São Paulo. Por isso não me refiro a elas de maneira retrospectiva e nem como produtos acabados, mas como projeto e como processo. Neste momento, sua possibilidade de existência depende do meu relato e dos outros registros que gerou durante sua etapa de produção.

A pergunta inicial 'Como discutir um trabalho que ainda não foi realizado em sua totalidade e nem exposto?' se converte em outra: 'Aonde está o trabalho?'. Esta é uma questão fundamental colocada por Monumetria, diria até que anterior ao projeto, uma dúvida que me acompanha desde antes e que, me parece, propiciou um interesse comum para o surgimento de DELENGUAAMANO. Qual é o lugar do trabalho na arte contemporânea? Será o objeto, estará no processo, será o autor, será o sistema de obras do autor, será o relato do autor, ou o relato do crítico, ou estará no projeto, ou no portfólio do artista, ou nas reproduções fotográficas e videográficas, ou talvez na relação entre as obras em uma curadoria. Não creio que esta pergunta possa ser respondida de maneira geral, pois se houvesse uma resposta única estaria desprovida de conflito e seria irrelevante.

No caso de Monumetria, a pergunta não é retórica, acompanhou seu processo de produção e lhe deu forma desde o começo, desde quando existia somente como discussão, e depois quando se tornou 
um projeto localizado na Pinacoteca, e agora, quando está sendo discutido no marco do meu projeto de mestrado.

O projeto apresentado à Pinacoteca (que é um dos capítulos deste trabalho) investiu na forma de apresentação do problema, que desde então já colocava em jogo as questôes que se pretendia discutir. Sua diagramação tem a forma de um mapa mental ou fluxograma, que nunca permite uma visão de totalidade. Se mostra como algo em movimento, incompleto, e capaz de diferentes combinaçôes. O projeto foi assumido como lugar do trabalho, a primeira materialização de Monumetria que poria as pautas para algumas formalizações futuras, sobretudo da publicação.

A publicação é um dos desdobramentos de Monumetria. Foi pensada como intervenção, acolhendo a forma 'livro' e suas possibilidades expressivas como lugar e meio de desenvolvimento do modus operandi do projeto, transformando-o. Mais especificamente, se apropria da forma 'catálogo', mas distanciando-se de sua pretensa transparência como transmissor e reminiscência da obra. A publicação é um fragmento do projeto, se apresenta como fragmento e como tal representa o projeto. Não pretende dar-lhe uma visão neutra nem totalizante. Mostra o projeto como pensamento dinâmico que em cada apresentação exige transformar-se e pensar-se como linguagem específica do meio e do lugar onde é representado. Um fragmento que se mostra como um pedaço de algo impossível se reconstituir, que não pretende juntar as partes e recriar o todo. Este todo nunca existiu e cada fragmento se aceita em sua unidade e incompletude.
Todas as intervenções de Monumetria se apropriam da linguagem institucional como campo de atuação. Mimetizam-se com o funcionamento institucional assumindo lugares geralmente considerados como alheios à obra ou secundários, negando-se a ocupar o espaço pré-determinado para a arte contemporânea. Cada intervenção individual responde à ressonância psicológica e ao funcionamento 'comum' de seu lugar e modo de apresentação.

'Perspectiva e projeção' acolhe uma forma de apresentação tradicionalmente usada para a exposição de registros. 'Trabalho e reprodução' se situa no Atrium Safra, espaço da Pinacoteca que expõe de forma permanente a escultura francesa do século XIX, sendo Rodin o centro das atençôes. Substitui a seqüência de moldes educativos usados para explicar o processo de fundição a partir de uma escultura de Rodin. 'Reconstituição' entra na loja da Pinacoteca como uma série de quatro cartôes postais com a possibilidade de serem vendidos como todos os outros. 'Mnemocine' se apresenta com a cara de uma exposição histórica, valendo-se de formas museológicas de exibição.

Como se vê, existe uma vontade de assumir os diferentes espaços que contém o trabalho e de trabalhar dentro dos parâmetros de suas linguagens. A aposta não é reproduzir o bom funcionamento destes aparatos, mas de discutir suas contradições e seus limites, reconhecendo seu status de 'realidade' e suas capacidade de produzir formas.

A pergunta que permanece: é possível representar um trabalho que se propõe a desdobrar-se em cada uma de suas apresentações? 


\section{Notas}

1. A palavra Monumetria é uma invenção de DELENGUAAMANO, um trocadilho composto por 'monumento' e 'metria' -de métrico-.

2. Gilberto Mariotti é mestrando em Artes, área de concentração Artes Plásticas, linha de pesquisa Poéticas Visuais, da Escola de Comunicações e Artes da Universidade de São Paulo ECA-USP, sob a orientação da Profa. Dra. Ana Maria Silva Araujo Tavares. Santiago Reyes é estudante de graduação do Programa de Artes Plásticas da Universidad de los Andes em Bogotá, Colômbia. Em 2008 participou do Programa de Intercâmbio no Departamento de Artes Plásticas da Escola de Comunicações e Artes da Universidade de São Paulo.

3. EMENDABILI, Galileo, in: FABRIS, Annateresa, 'Monumentto a Ramos de Azevedo: Do Concurso ao Exílio', Mercado de Letras, Campinas, 1997, pg. 38.

4. Para se referir ao aparato mnemônico humano e às características perceptivas nele desenvolvidas, Freud fez uma analogia com um objeto chamado de Bloco Místico: um objeto de resina marrom ou cera com bordas de papel, cuja superfície é uma membrana fina e transparente, firmemente segurada na parte de cima do objeto e solta na parte de baixo. No aparato se escreve fazendo pressão sobre a membrana, sem necessidade de depositar outro material nesta superfície receptiva. Para apagar o que for escrito só é necessário se levantar a membrana e dessa forma a superfície fica pronta para ser usada de novo e receber mais informação. Mas se a membrana for tirada completamente, ficam à vista na resina ou na cera todas as impressóes sobrepostas sobre ela escritas -que permanecem por sempre- : FREUD, Sigmund, 'A Note Upon The Mystic Writing-Pad', in: MEREWETHER(org.), Charles, 'The Archive', Whitechapel, Londres, The MIT Press, Cambridge Massachusetts, 2006, pg. 20.

5. Ver o capítulo Monumetria: O Projeto.

6. Ver o capítulo Monumetria: O Projeto.

7. Ver o capítulo Monumetria: O Projeto.

8. Ver o capítulo Monumetria: O Projeto.

9. Ver o capítulo Monumetria: O Projeto.

10. Ver o capítulo Monumetria: O Projeto. 


\section{Bibliografía}

- ADORNO, Theodor, 'The Valéry Proust Museum', in: 'Prisms', Samuel e Sherry Weber, Cambridge University Press, Cambridge, Mass., 1981.

- AIRA, César, 'Um Acontecimento na Vida do Pintor-Viajante', Editora Nova Fronteira, Rio de Janeiro, 2007.

- AUGÉ, Marc, 'Los No Lugares: Espacios del Anonimato: Una Antropología de la Sobremodernidad', Barcelona, 1993.

- AZEVEDO, Ricardo, 'Metrópole: Abstração', Perspectiva, São Paulo, 2006. - BARTHES, Roland, 'A Câmara Clara: Nota Sobre a Fotografía', Editora Nova Fronteira, Rio de Janeiro, 1984.

- BAUMAN, Zygmunt, 'Modernidade Liquida’, Jorge Zahar Editor, Rio de Janeiro, 2001.

- BENJAMIN, Walter, 'Obras Escolhidas: Magia e Técnica, Arte e Política’, Editora Brasiliense, 1996.

- BENJAMIN, Walter, 'Alegoria e Drama Barroco', in: 'Walter Benjamin: Documentos de Cultura, Documentos de Barbárie (Escritos Escolhidos)', seleção e apresentação de Willi Bolle, Cultrix, Edusp, São Paulo, 1986.

- BERMAN, Marshall, 'Tudo que é Sólido Desmancha no Ar: A Aventura da Modernidade', Companhia das Letras, São Paulo, 1986.

- BLANCHOT, Maurice, 'Time, Art and the Museum' in: 'Malraux: A Collection of Critical Essays', Prentice Hall, Englewood-Cliff, New Jersey, R.W.B. Lewis, 1993.

- BRETON, André, 'Manifestos do Surrealismo', Editora Brasiliense, São Paulo, 19?
- BRISSAC PEIXOTO, Nelson, 'Paisagens Urbanas', Editora Senac, São Paulo, 2004

- BRUNELLI ZIMMERMANN, Silvana, 'A Obra Escultórica de Galileo Emendabili: Uma Contribuição para o Meio Artístico Paulistano', dissertação de mestrado apresentada ao departamento de Artes Plásticas da Escola de Comunicaçôes e Artes da Universidade de São Paulo, orientadora: Profa. Dra, Annateresa Fabris, São Paulo, 2000.

- BURGUER, Peter, 'Teoria da Vanguarda', Cosac \& Naify, São Paulo, 2008 .

- CHÉNIEUX-GENDRON, Jacqueline, 'O Surrealismo', Martins Fontes, São Paulo, 1992.

- CHIARELLI, Tadeu, 'A Obra de Galileo Emendabili: Síntese e Superação de Influências', in: 'Monumento a Ramos de Azevedo: do Concurso ao Exílio', Mercado de Letras, Campinas, 1997.

- CRIMP, Douglas, 'On the Museum's Ruins', The MIT Press, Cambridge, Massachusetts, London, 1993.

- FABRIS, Annateresa, 'Monumento a Ramos de Azevedo: do Concurso ao Exílio', Mercado de Letras, Campinas, 1997.

- FABRIS, Annateresa, 'Fragmentos Urbanos: Representaçôes Culturais', Studio Nobel, São Paulo, 2000.

- FLUSSER, Vilém, 'Filosofia da Caixa Preta: Ensaios para uma Futura Filosofia da Fotografia', Relume Dumará, Rio de Janeiro, 2002.

- FOUCAULT, Michel, 'The Historical a priori and the Archive', in: 'The Archive', editado por Charles Merewether, Whitechapel, London, The MIT Press, Cambridge, Massachusetts, 2006.

- FRANÇA LOURENÇO, Maria Cecília (org.), 'Homenagem aos 
Mestres: Esculturas na USP’, Edusp, São Paulo, 2002.

- FRANÇA LOURENÇO, Maria Cecília (org.), 'Obras Escultóricas em Espaços Externos da USP', Edusp, São Paulo, 1997.

- FREUD, Sigmund, 'A Note Upon The Mystic Writing-Pad', in: 'The Archive', editado por Charles Merewether, Whitechapel, London, The MIT Press, Cambridge, Massachusetts, 2006.

- HILDEBRAND VON, Adolf, 'El Problema de la Forma en la Obra de Arte', Visor, Madrid, 1988.

- JAKOBSON, Roman, 'Lingüística e Comunicação', Editora Cultrix, São Paulo, 19?

- KRAUSS, Rosalind, 'Caminhos da Escultura Moderna', Martins Fontes, São Paulo, 2001.

- KRAUSS, Rosalind, 'The Originality of the Avant-Garde and Other Modernist Myths', The MIT Press, Cambridge, Massachusetts, London, 1985

- KWON, Miwon, 'One Place After Another: Site-Specific Art and Locational Identity', The MIT Press, Cambridge, Massachusetts, 1999.

- LE GOFF, Jacques, 'História e Memória', Editora Unicamp, Campinas, 2005.

- LÉVI-STRAUSS, Claude, 'Tristes Trópicos', Eudeba -Editorial Universitaria de Buenos Aires-, Buenos Aires, 1973.

-LYOTARD, Jean-François, 'O Pós-Moderno', José Olympio Editora, Rio de Janeiro, 1986.

- MALRAUX, André, 'The Voices of Silence', Princeton University Press, Princeton, 1978.
- NAVES, Rodrigo, 'Debret, o Neoclassicismo e a Escravidão', in: 'A

Forma Difícil', Atica, São Paulo, 1997.

- RESTREPO, José Alejandro, 'Cuerpo Gramatical: Cuerpo, Arte y Violencia', Ediciones Uniandes, Bogotá, 2006.

- SALGADO LOUREIRO, Maria Amélia, 'A Evolução da Casa Paulistana e a Arquitetura de Ramos de Azevedo', Voz do Oeste, São Paulo, 1981.

- SEGAWA, Hugo, 'Arquiteturas no Brasil: 1900-1990', Editora da Universidade de São Paulo, São Paulo, 1998.

- SEKULA, Alan, 'Photography Between Labor and Capital', in: 'Mining Photographs and Other Pictures: A Selection from the Negative Archives of Shelddon Studio, Glace Bay, Cape Breton', Press of the Nova Scotia College of Art and Design, Nova Scotia, 1983.

- SIMMEL, GEORG, 'A Metrópole e a Vida Mental', in: 'O Fenômeno Urbano', Otávio Guilherme Velho (org.), Zahar Editores, Rio de Janeiro, 1973.

- SMITHSON, Robert, 'Robert Smithson: The Collected Writings', Jack Flam (org.) University of California Press, Berkeley, Los Angeles, 1996.

- SONTAG, Susan, 'On Photography', Ferrar, Straus and Giroux, New York, 1977.

- STEINBERG, Leo, 'Outros Critérios: Confrontos com a Arte do Século XX', Cosacnaify, São Paulo, 2008.

- WOLFF DE CARVALHO, Maria Cristina, 'Ramos de Azevedo', Editora da Universidade de São Paulo, São Paulo, 2000. 


\section{Agradecimentos}

Agradeço muito especialmente a um grupo de pessoas que influiu diretamente sobre este trabalho: Ana Tavares, Carlos Fajardo, El Chino, La China, Giba, Santiago, Marcia, Danilo e Luanda. Sem vocês não teria sido possível. 